\title{
6. SITE 370: DEEP BASIN OFF MOROCCO
}

\author{
The Shipboard Scientific Party ${ }^{1,2}$
}

\section{SITE DATA}

Date Occupied: 29 March 1975 (0100Z)

Date Departed: 8 April $1975(0110 \mathrm{Z})$

Time on Site: 10 days and 10 minutes

Position: $32^{\circ} 50.2^{\prime} \mathrm{N}, 10^{\circ} 46.6^{\prime} \mathrm{W}$

Water Depth (sea level): 4214 corrected meters (echo sounding)

Bottom Felt With Drill Pipe at: 4226 meters (below rig floor)

Penetration: 1176.5 meters

Number of Holes: 1

Number of Cores: 51

Total Length of Cored Section: 483 meters

Total Core Recovered: 202.7 meters

\section{BACKGROUND AND OBJECTIVES}

\section{Background}

The deep basin off the Atlantic coast of Morocco offers a particularly good opportunity to sample old sediments very close to the continental margin because of the almost complete absence of a continental rise along that margin. A survey conducted by LamontDoherty's Vema (Vema 30) showed that sediment possibly as old as Middle Jurassic should be within reach of the Glomar Challenger.

The site is located well within the magnetic quiet zone $(\approx 300 \mathrm{~km}$ from the boundary) and very close to the base of the Moroccan continental slope (Figure 1).

\footnotetext{
'Yves Lancelot, Lamont-Doherty Geological Observatory, Palisades, New York (Co-Chief Scientist); Eugen Seibold, Geologisch-Palaontologisches, Institüt und Museum der Universität Kiel, Kiel, Germany (Co-Chief Scientist); Pavel Cepek, Bundesanstalt für Bodenforschung, Hannover, Federal Republic of Germany; Walter E. Dean, Syracuse University, Department of Geology, Syracuse, New York; Vladislav Eremeev, Institute of Geological Sciences of the Academy of Sciences, Laboratory of Lithology Formation, Moscow, USSR; James Gardner, Deep Sea Drilling Project, Scripps Institution of Oceanography, La Jolla, California; Lubomir F. Jansa, Atlantic Geoscience Centre, Geological Survey of Canada, Bedford Institute of Oceanography, Dartmouth, Nova Scotia; David Johnson, Woods Hole Oceanographic Institution, Woods Hole, Massachusetts; Valery K rasheninnikov, Geological Institute of the Academy of Sciences of the USSR, Moscow, USSR; Uwe Pflaumann, GeologischPalaontologisches, Institüt und Museum der Universität Kiel, Kiel, Germany; J. Graham Rankin, Northeast Louisiana University, Department of Chemistry, Monroe, Louisiana; Peter Trabant, Texas A\&M University, Department of Oceanography, College Station, Texas.

${ }^{2}$ David Bukry, U.S. Geological Survey, La Jolla, California (Tertiary nannofossils).
}

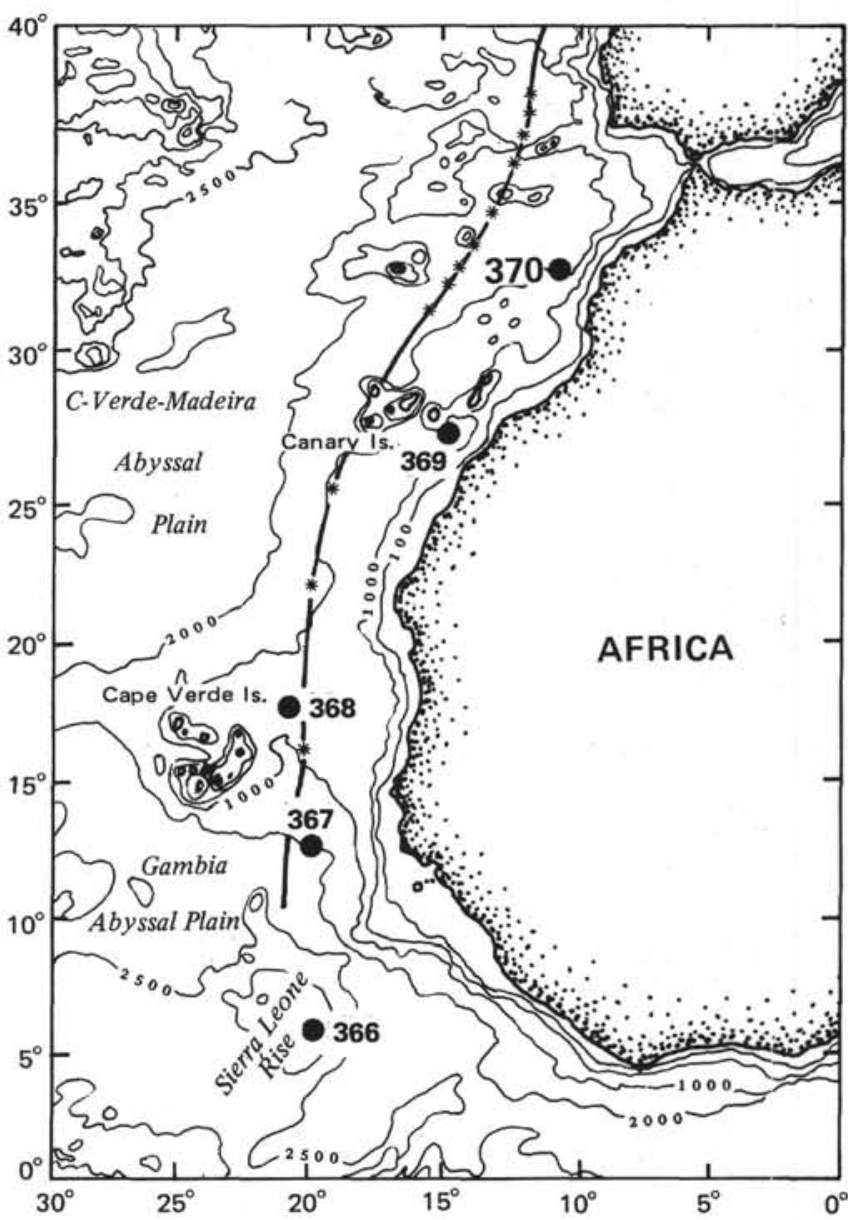

If we assume the basement to be oceanic, and if we extrapolate the Upper Jurassic spreading rate derived from the Mesozoic anomalies, then the age of the basement at Site 370 could be as old as Lower Jurassic $(\approx 165$ to 170 m.y.). Without "re-entry" capability, there was no chance to reach the lowermost sediments and the basement. However, there were good reasons to believe that Upper to Middle Jurassic sediments could lie at depths of about 1300-1400 meters subbottom.

Seismic-reflection profiles recorded in the area north of the Canary Islands display a succession of roughly parallel reflectors over a very faint rough reflector that may be interpreted as basement (Figure 2a). The reflectors observed above the basement can only be tentatively correlated with reflectors from the basins south of the Canary Islands, because correlations are very difficult across that volcanic massif or across the tectonic zone that possibly links the Canary Islands to the Atlas area on the African margin and continent south of Agadir. Holes drilled during Leg 14 (Sites 135 


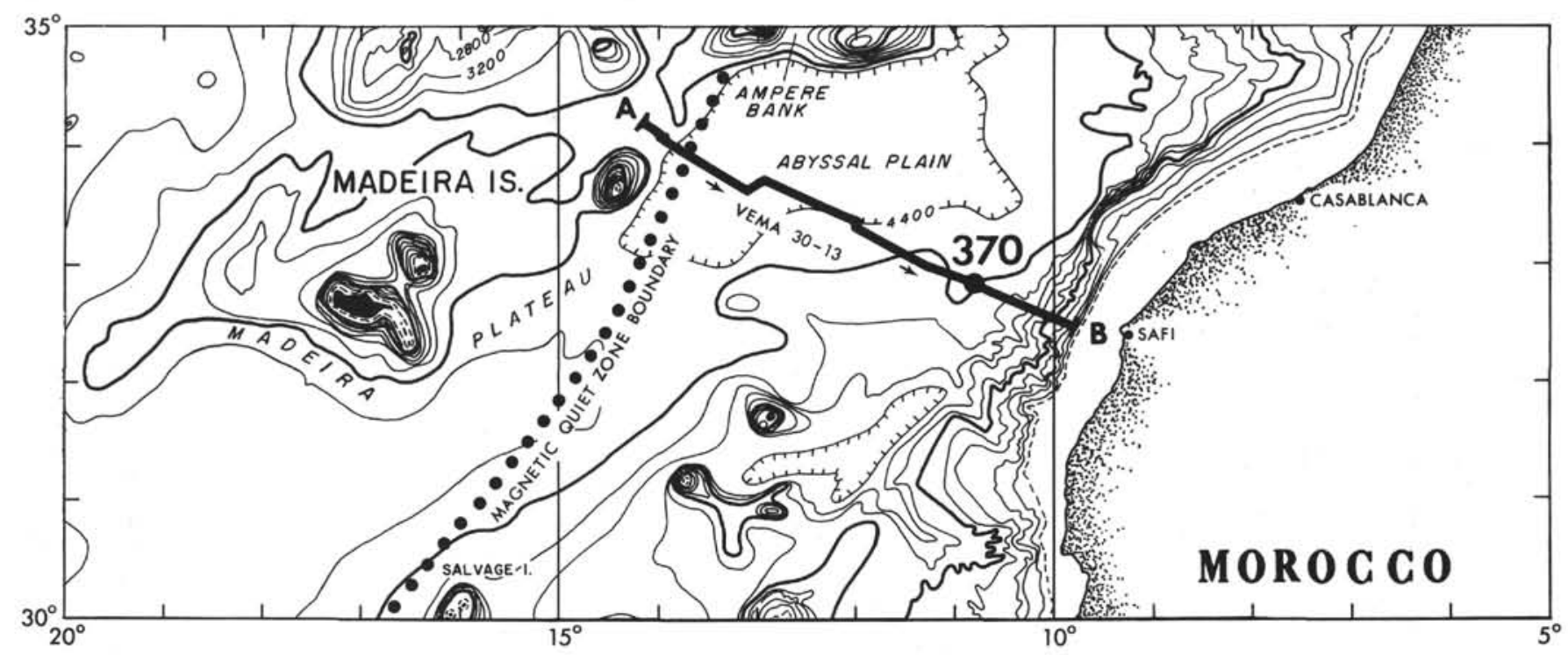

Figure 1. Location of Site 370 in the Morocco Basin. Bathymetry from Uchupi (1971) and magnetic quiet zone boundary from Hayes and Rabinowitz, 1975.

and 136, Hayes, Pimm, et al., 1972) do not provide a good control for the nature and age of these reflectors because they cannot be directly tied to these drill sites. Furthermore, Site 135 was drilled on a topographic high which resulted from an early Eocene uplift that considerably influenced the sedimentation. The oldest part of the Mesozoic magnetic anomaly pattern just west of the quiet zone is still incompletely mapped and complicated by the occurrence of a linear anomaly (anomaly J) that might be related to basement features instead of a field reversal. It was therefore particularly important to try to obtain a good record of the sedimentary evolution of that part of the Atlantic in order to compare it with the results of Site 367 drilled south of the Canary Islands-Atlas tectonic zone as well as Site 105 drilled south of the New England seamount lineament in the western basin. The objectives for this site had a dual aspect: (1) to determine the nature and age of the oldest sediments that could be reached by drilling; and (2) to identify the overlying sedimentary units and the nature and age of the reflectors.

On both sides of the North Atlantic, the oldest sediments recovered are of Middle to Late Jurassic age. As for Site 367, our assumption was that reflector C, observed as the first major reflector below a reflector believed to correspond with Horizon $\beta$ (Figure 2a), corresponds with sediments of Oxfordian age (see discussion in Site 367 report). At Site 367 that reflector was rather badly defined and was found to correspond with Jurassic limestones just overlying basaltic basement. At Site 370 several reflectors are present below the level of what is believed to be reflector $\mathrm{C}$ and the only factor that would prevent recovery of Middle or Lower Jurassic sediment should have been the technical limitations of the drilling equipment.

The seismic profile from which Site 370 was selected (profile Vema 30, Figures 2a and 2b) shows a series of reflectors that have been tentatively correlated with the major reflector observed in the basins south of the Canary Islands. The uppermost of these reflectors might correspond to the reflector identified at Sites 368 and 369 as well as at Sites 139 and 140 (Leg 14, Hayes, Pimm, et al., 1972) as the base of carbonate-rich layers of Miocene age. Precise correlations, however, are difficult as the age of that reflector appears to vary from site to site. On the other hand, this reflector might also be the equivalent of Horizon $\mathrm{A}$ and correspond with Eocene silicified layers as at previous sites drilled south of the Canary Islands. The age of the lower reflectors can be only estimated in an indirect way by trying to determine on the profiles where they come into contact with basement. On that basis we can tentatively observe reflector $\mathrm{C}$ reaching basement in the vicinity of the quiet magnetic zone boundary and therefore it can be assumed to be of approximately Late to Middle Jurassic age by comparison with the results of Sites 105 (Leg 11) and 367 (this leg). The reflector or reflectors lying between the uppermost reflector and reflector $C$ could correspond to $\beta$ or possibly $\mathrm{A}^{*}$. Because the seismic profile shows only a low frequency record (an attempt to achieve better penetration), the definition is not very good and only broad reflecting zones can be observed.

Site 370 is located in a slight depression between the Moroccan margin and a broad elevation located just east of the margin that reaches depths of about 4000 meters whereas the nearby Seine Abyssal Plain shows average depths of 4600 meters. The depression does not appear to be filled with ponded terrigenous sediments so that the sediment thicknesses appear most favorable for an attempt at reaching the level of reflector $\mathrm{C}$. The site is located in a synclinal structure and well seaward of the zone of diapiric features along the margin so that no possible accumulations of hydrocarbons were expected.

\section{Objectives}

Our first priority objective at this site was to try to reach reflector $C$ and determine the nature and age of the sediments immediately below that level. Oxfordian 


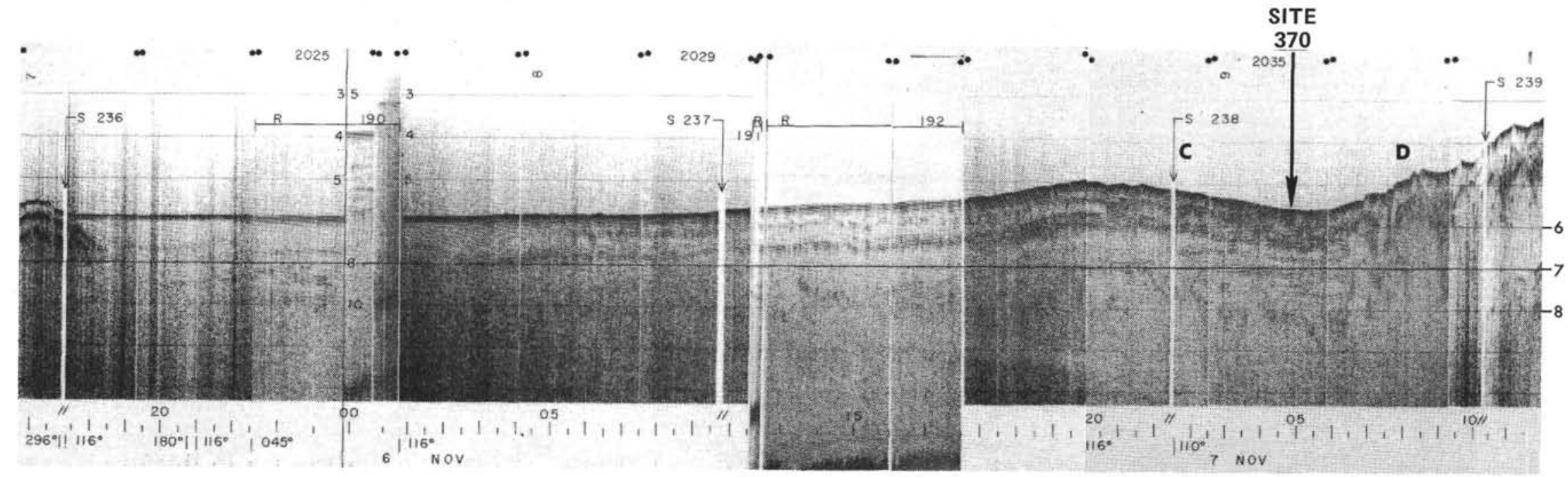

A

MAGNETIC

ROUGH/QUIET ZONE

BOUNDARY

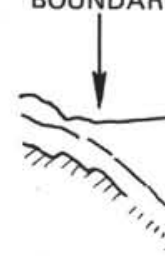

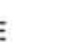$$
\text { Nor }
$$

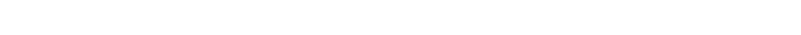

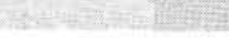




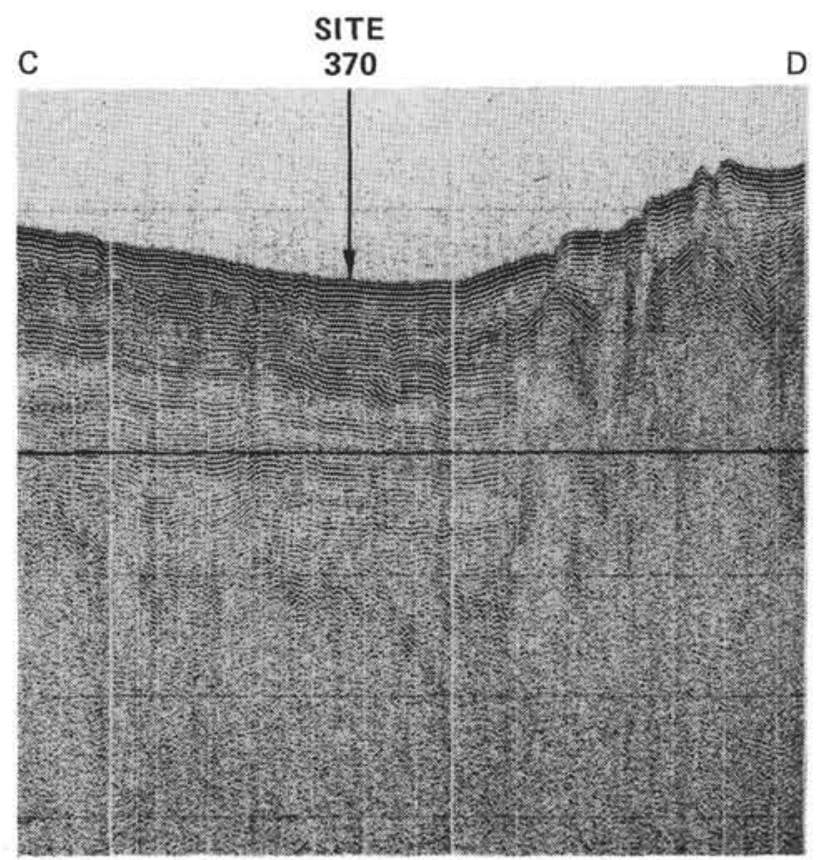

Figure 2b. Closeup of Figure $2 a$ in area around Site 370.

ammonite-rich limestones have been recovered by dredging the nearby continental slope (Renz et al., 1975). The Oxfordian rocks at Site 367 and on the slope are open marine facies showing strong affinities with the "Ammonitico Rosso" facies of the Tethyan realm. The middle Oxfordian in Morocco is marked by a very abrupt transgression where open marine conditions suddenly replace continental to lagoonal environments (Haha Basin). In the same region, the shallow water marine facies of the Lower Jurassic are indicative of relatively restricted environments and do not show good connections with the open marine Tethyan environments. It is therefore particularly interesting to try to understand what could be the significance of the Oxfordian transgression in the Atlantic basin itself. If the pre-Oxfordian facies in the basins are of the Tethys type, then the implication would be that the connection between Tethys and the young Atlantic was already well established but restricted to the deep basin. If, however, the connection did not exist prior to the Oxfordian, then the sediments found below reflector C should reflect a different environment, possibly very restricted and characteristic of the more or less isolated young Atlantic Ocean. Because the evaporites found on the margin could be of early Jurassic age and because diapiric structures that closely resemble salt domes are observed in the deep basin, it might be speculated that their origins lie in these restricted environmental conditions.

Our second objective was to obtain as complete a sedimentary record from the deep basin as possible and compare the evolution of this area with that of the Canary and Cape Verde basins as well as of the western Atlantic. The history of this deep basin is still unknown because the only two previous drilling attempts were located either on the outer edge of the deep basin (Site 136, Leg 14) or on an uplifted piece of oceanic crust (Site 135, Leg 14).

\section{Strategy}

Because this site is located only about 2 days of steaming time from Malaga, the end point of this cruise, the drilling program for this site had to receive special consideration. Because the major objective lay at great depth, it was aimed at first, therefore only intermittent coring was performed in the upper part of the hole down to a level at which closely spaced coring became both a technical and safety oriented necessity. Then, coring would be continuous or semicontinuous down to the maximum depth that could be achieved before the bit was destroyed. The drill string would be pulled out of the hole and, if time permitted the bit would be brought on deck, exchanged for a new one, and an "A" hole would be drilled and cored down to the level where closely spaced coring was initiated. The density of coring would be dictated by the amount of time remaining before the site had to be abandoned in order to meet our ETA in Malaga. If only a small amount of time was available and if, although damaged, the first bit was not plugged, then punchcoring of the uppermost section would be attempted directly without bringing the old bit on deck.

\section{OPERATIONS}

The area of Site 370 was approached from the southwest and, using the same procedure as for the previous sites, it was decided to intercept the LamontDoherty Vema 30 track at a point located about $16 \mathrm{~km}$ from the site in order to match the Glomar Challenger profile with the Lamont-Doherty reference profile. The intercept point was reached at 2151 on 28 March 1975, and the ship headed toward the site on a $104^{\circ}$ course (Figure 3). The seismic record (Figure 4) was comparable to the Lamont-Doherty profile (Figure 2) but with a lesser penetration. At 2203 the speed was reduced to approximately 5 knots in order to increase the penetration on the seismic record. Still the penetration was not sufficient for suitable comparisons with the Lamont-Doherty record for the deeper part of the section and the site had to be recognized from the morphology of the upper reflectors. After a suitable location was selected the ship executed a Williamson turn to make a second pass over the site and drop the beacon. At 0006 on 29 March, an ORE 16-kHz beacon was dropped, and the seismic and magnetic gear were immediately retrieved. The ship executed a second turn and came back toward the beacon. By that inie, weather conditions had deteriorated and strong winds of about 40 knots, gusting to 55 knots, made the final approach difficult. The "lock on" was effective at about 0100 , but running in the drill pipe was delayed because of the weather conditions. The ship had to use almost all the power available to stay over the beacon which left only marginal power for the draw works. The roll and pitch motion generally was exceeding $5^{\circ}$. Both factors prevented safe operations on the rig floor and more than 18 hours were spent waiting for better weather conditions. At 1945 on 29 March, the wind and swell had reduced sufficiently to allow for running the drill pipe and operations began. The sea bottom was felt by the driller at 0625 on 30 March when the total length of drill pipe reached 4226 meters from the rig 


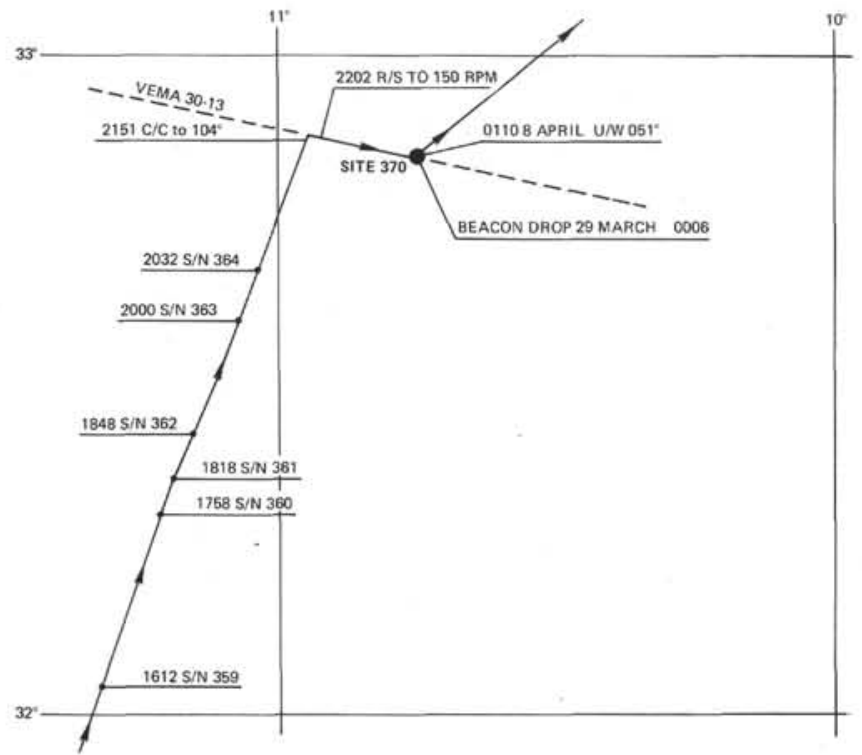

Figure 3. Glomar Challenger tracks (solid line) approaching and departing Site 370 and Vema 30 tracks (dashed line).

floor. The water depth from sea level was officially considered to be 4216 meters. This depth shows relatively good agreement with the PDR depth of 4214 meters corrected (from sea level).

The drilling and coring program consisted of spot coring as far down as technically possible (see Table 1). After taking a surface core the bit was lowered by washing down to a subbottom depth of 103 meters and a core was punched from 103 to 112.5 meters. Because the core barrel was in place at the end of the drill string during the washing operation, it is probable that some sediments might have accidentally entered the barrel between 8 and 103 meters subbottom. The same operation was repeated from 112.5 to 207.5 meters and Core 3 was cut from 207.5 meters to 217 meters. Because Cores 2 and 3 showed evidence of possible admixture of different lithologies, we felt that the cores might not be truly representative of the level at which they were taken. Therefore, we decided to revert to the technique used on previous sites when spot coring. That technique consists of taking a core before washing an interval so that the barrel would be already full when washing operations begin. Cores 4,5 , and 6 were obtained this way and after the sediments became firmer, closely spaced coring began with Core 6 at 426 meters below the bottom. Coring was closely spaced to continuous and relatively slow down to about 750 meters. Very sticky clays proved to be difficult to penetrate with the medium length insert bit and drilling/coring became extremely slow below 768 meters. Pulling out of the hole and exchanging the bit was considered but, because of time constraints at the end of the leg, we thought this operation would not improve the total penetration. Alternating drilling and coring, with very slow rate of penetration, continued down to a total depth of 1176.5 meters below the sea floor. After recovering the last core (Core 51) time constraints for meeting the scheduled arrival date at Malaga dictated our decision to abandon the hole. The drill string was recovered and the drill bit was on deck at 0047 on 8 April. That bit had drilled for a record time of $121 \mathrm{hr}$. and $59 \mathrm{~min}$. The ship was under w.y at 0110 on 8 April and the post-site survey consisted only in a run at slow speed over the beacon on a course approximately perpendicular to the approach track. Fifteen minutes after passing over the beacon, speed was increased and course was set toward the Gibraltar straits and Malaga.

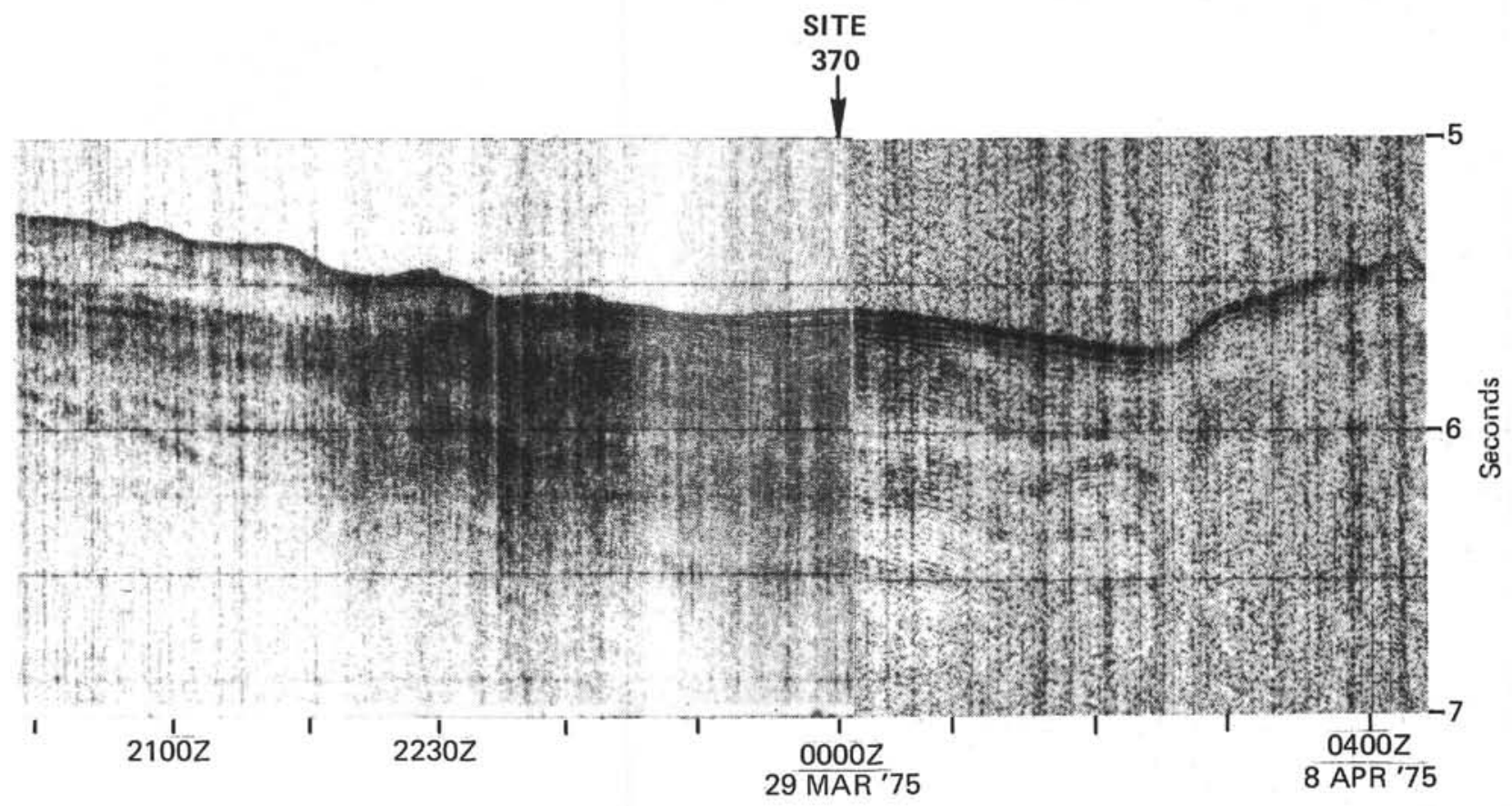

Figure 4. Glomar Challenger seismic-reflection profile approaching and leaving Site 370. 
TABLE 1

Coring Summary for Site 370

\begin{tabular}{|c|c|c|c|c|c|c|c|}
\hline Core & $\begin{array}{c}\text { Date } \\
\text { (March 1975) }\end{array}$ & Time & $\begin{array}{l}\text { Depth From } \\
\text { Drill Floor (m) }\end{array}$ & $\begin{array}{l}\text { Depth Below } \\
\text { Sea Floor }(m)\end{array}$ & $\begin{array}{l}\text { Cored } \\
\text { (m) }\end{array}$ & $\begin{array}{l}\text { Recovered } \\
\text { (m) }\end{array}$ & $\begin{array}{c}\text { Recovered } \\
(\%)\end{array}$ \\
\hline 1 & 30 & 0714 & $4226.0-4234.0$ & $0.0-8.0$ & 8.0 & 6.5 & 81 \\
\hline 2 & 30 & 1115 & $4329.0-4338.5$ & $103.0-112.5$ & 9.5 & 2.5 & 26 \\
\hline 3 & 30 & 1400 & $4433.5-4443.0$ & $207.5-217.0$ & 9.5 & 3.1 & 33 \\
\hline 4 & 30 & 1650. & $4443.0-4452.5$ & $217.0-226.5$ & 9.5 & 5.1 & 54 \\
\hline 5 & 30 & 2117 & $4547.5-4557.0$ & $321.5-331.0$ & 9.5 & 8.5 & 90 \\
\hline 6 & 31 & 0021 & $4652.0-4661.5$ & $426.0-435.5$ & 9.5 & 2.3 & 24 \\
\hline 7 & 31 & 0317 & $4671.0-4680.5$ & $445.0-454.5$ & 9.5 & 2.0 & 21 \\
\hline 8 & 31 & 0610 & $4690.0-4699.5$ & $464.0-473.5$ & 9.5 & 1.9 & 20 \\
\hline 9 & 31 & 0915 & $4709.0-4718.5$ & $483.0-492.5$ & 9.5 & 1.0 & 11 \\
\hline 10 & 31 & 1239 & $4728.0-4737.5$ & $502.0-511.5$ & 9.5 & 1.8 & 19 \\
\hline 11 & 31 & 1628 & $4747.0-4756.5$ & $521.0-530.5$ & 9.5 & 0.1 & 1 \\
\hline 12 & 31 & 1945 & $4766.0-4775.5$ & $540.0-549.5$ & 9.5 & 2.3 & 24 \\
\hline \multirow[t]{2}{*}{13} & 31 & 2223 & $4775.5-4785.0$ & $549.5-559.0$ & 9.5 & 1.8 & 19 \\
\hline & April & & & & & & \\
\hline 14 & 1 & 0107 & $4794.5-4804.0$ & $568.5-578.0$ & 9.5 & 4.8 & 51 \\
\hline 15 & 1 & 0339 & $4813.5-4823.0$ & $587.5-597.0$ & 9.5 & 4.2 & 44 \\
\hline 16 & 1 & 0600 & $4832.5-4842.0$ & $606.5-616.0$ & 9.5 & 5.0 & 53 \\
\hline 17 & 1 & 0953 & $4842.0-4851.5$ & $616.0-625.5$ & 9.5 & 2.5 & 26 \\
\hline 18 & 1 & 1318 & $4861.0-4870.5$ & $635.0-644.5$ & 9.5 & 2.8 & 30 \\
\hline 19 & 1 & 1711 & $4880.0-4889.5$ & $654.0-663.5$ & 9.5 & 1.2 & 13 \\
\hline 20 & 1 & 2036 & $4899.0-4908.5$ & $673.0-682.5$ & 9.5 & 4.1 & 43 \\
\hline 21 & 1 & 2245 & $4908.5-4918.0$ & $682.5-692.0$ & 9.5 & 2.9 & 31 \\
\hline 22 & 2 & 0101 & $4918.0-4927.5$ & $692.0-701.5$ & 9.5 & 6.0 & 63 \\
\hline 23 & 2 & 0326 & $4927.5-4937.0$ & $701.5-711.0$ & 9.5 & 5.4 & 57 \\
\hline 24 & 2 & 0542 & $4937.0-4946.5$ & $711.0-720.5$ & 9.5 & 6.5 & 68 \\
\hline 25 & 2 & 0800 & $4946.5-4956.0$ & $720.5-730.0$ & 9.5 & 2.1 & 22 \\
\hline 26 & 2 & 1133 & $4956.0-4965.5$ & $730.0-739.5$ & 9.5 & 5.8 & 61 \\
\hline 27 & 2 & 1537 & $4975.0-4984.5$ & $749.0-758.5$ & 9.5 & 4.0 & 42 \\
\hline 28 & 2 & 1846 & $4994.0-5003.5$ & $768.0-777.5$ & 9.5 & 5.1 & 54 \\
\hline 29 & 3 & 0352 & $5013.0-5022.5$ & $787.0-796.5$ & 9.5 & 0.8 & 8 \\
\hline 30 & 3 & 1145 & $5032.0-5041.5$ & $806.0-815.5$ & 9.5 & 6.1 & 64 \\
\hline 31 & 3 & 1601 & $5051.0-5060.5$ & $825.0-834.5$ & 9.5 & 6.1 & 64 \\
\hline 32 & 3 & 1953 & $5060.5-5070.0$ & $834.5-844.0$ & 9.5 & 5.2 & 55 \\
\hline 33 & 3 & 2313 & $5079.5-5089.0$ & $853.5-863.0$ & 9.5 & 0.2 & 2 \\
\hline 34 & 4 & 0237 & $5098.5-5108.0$ & $872.5-882.0$ & 9.5 & 7.1 & 75 \\
\hline 35 & 4 & 0740 & $5108.0-5117.5$ & $882.0-891.5$ & 9.5 & 7.1 & 75 \\
\hline 36 & 4 & 1316 & $5127.0-5136.5$ & $901.0-910.5$ & 9.5 & 0.2 & 2 \\
\hline 37 & 4 & 1648 & $5146.0-5155.5$ & $920.0-929.5$ & 9.5 & 0.2 & 2 \\
\hline 38 & 4 & 2112 & $5165.0-5174.5$ & $939.0-948.5$ & 9.5 & 6.7 & 71 \\
\hline 39 & 5 & 0159 & $5174.5-5184.0$ & $948.5-958.0$ & 9.5 & 6.0 & 63 \\
\hline 40 & 5 & 0607 & $5193.5-5203.0$ & $967.5-977.0$ & 9.5 & 5.7 & 60 \\
\hline 41 & 5 & 1059 & $5212.5-5222.0$ & $986.5-996.0$ & 9.5 & 7.7 & 81 \\
\hline 42 & 5 & 1503 & $5231.5-5241.0$ & $1005.5-1015.0$ & 9.5 & 4.7 & 50 \\
\hline 43 & 5 & 2030 & $5250.5-5260.0$ & $1024.5-1034.0$ & 9.5 & 5.2 & 55 \\
\hline 44 & 5 & 2329 & $5269.5-5279.0$ & $1043.5-1053.0$ & 9.5 & 4.4 & 46 \\
\hline 45 & 6 & 0343 & $5288.5-5298.0$ & $1062.5-1072.0$ & 9.5 & 5.5 & 58 \\
\hline 46 & 6 & 0915 & $5307.5-5317.0$ & $1081.5-1091.0$ & 9.5 & 6.4 & 67 \\
\hline 47 & 6 & 1445 & $5326.5-5336.0$ & $1100.5-1110.0$ & 9.5 & 4.1 & 43 \\
\hline 48 & 6 & 2038 & $5345.5-5355.0$ & $1119.5-1129.0$ & 9.5 & 3.2 & 34 \\
\hline 49 & 7 & 0227 & $5364.5-5374.0$ & $1138.5-1148.0$ & 9.5 & 4.0 & 42 \\
\hline 50 & 7 & 0726 & $5383.5-5393.0$ & $1157.5-1167.0$ & 9.5 & 2.8 & 30 \\
\hline 51 & 7 & 1210 & $5393.0-5402.5$ & $1167.0-1176.5$ & 9.5 & 2.0 & 21 \\
\hline Total & & & & & 483.0 & 202.7 & 42 \\
\hline
\end{tabular}

\section{LITHOLOGY}

We subdivided the section into five units based on changes in color and composition (Table 2).

Unit 1: Nanno-foram bearing clay (Core 1)

Unit 1 consists of yellowish brown (10YR6/2), soupy clay containing common nannofossils and foraminifers, and rare quartz silt, carbonate rhombs, and ferromanganese or iron sulfide micronodules.

Unit 2 consists of two subunits:

Subunit 2a: Clayey nanno ooze (Cores 1 through 2, Section 2).
Subunit 2b: Silty nanno marl interbedded with calcareous silt and sand (Core 2, Section $2,30 \mathrm{~cm}$ through Core 3, Section 1, $84 \mathrm{~cm}$ ):

Subunit $2 a$ is light greenish gray ( $5 \mathrm{GY} 6 / 1)$ clayey nannofossil ooze composed of dominant nannofossils, common clay, rare foraminifers and carbonate rhombs, and traces of zeolites and heavy minerals. The nannofossil ooze is homogeneous, soft, sticky, and highly disturbed by drilling so that primary sedimentary structures are not preserved. The base of the subunit is an $80-\mathrm{cm}$-thick bed of grayish orange nannofossil ooze. 
TABLE 2

Lithostratigraphy at Site 370

\begin{tabular}{|c|c|c|c|}
\hline Unit & Lithology & Cores & Age \\
\hline 1 & $\begin{array}{l}\text { Nannofossil-foraminiferous-bearing } \\
\text { clay }\end{array}$ & 1 & Quaternary \\
\hline $2 \mathrm{a}$ & Clayey nannofossil ooze and marls & $\begin{array}{l}1 \text { through } 2, \text { Section } 2 \text { to } 30 \mathrm{~cm} \\
(0 \text { ? to } 106.3 \mathrm{~m})\end{array}$ & Pliocene \\
\hline $2 \mathrm{~b}$ & $\begin{array}{l}\text { Clayey nannofossil ooze with silt } \\
\text { and sand beds }\end{array}$ & $\begin{array}{l}\text { 2, Section } 2 \text { to } 30 \mathrm{~cm} \text {, Section } \\
1 \text { to } 84 \mathrm{~cm} \\
(106.3 \text { to } 208.46 \mathrm{~m})\end{array}$ & $\begin{array}{l}\text { Middle Miocene to } \\
\text { Pliocene }\end{array}$ \\
\hline $3 \mathrm{a}$ & $\begin{array}{l}\text { Nannofossil radiolarian-bearing } \\
\text { clay }\end{array}$ & $\begin{array}{l}\text { 3, Section } 1 \text { to } 84 \mathrm{~cm} \text { through } 4 \\
\text { (208.46 to } 226.5 \mathrm{~m} \text { ) }\end{array}$ & $\begin{array}{l}\text { Middle to early } \\
\text { Miocene }\end{array}$ \\
\hline $3 \mathrm{~b}$ & $\begin{array}{l}\text { Calcareous silty clay with } \\
\text { porcellanite }\end{array}$ & $\begin{array}{l}5 \text { through } 11 \\
(321.5 \text { to } 530.5 \mathrm{~m})\end{array}$ & $\begin{array}{l}\text { Oligocene to middle } \\
\text { Eocene }\end{array}$ \\
\hline $3 \mathrm{c}$ & $\begin{array}{l}\text { Calcareous silty claystone with silt, } \\
\text { sand, porcellanite, and chert }\end{array}$ & $\begin{array}{l}12 \text { through } 18 \\
(540 \text { to } 644.5 \mathrm{~m})\end{array}$ & $\begin{array}{l}\text { Middle Eocene to } \\
\text { early Eocene }\end{array}$ \\
\hline 4 & $\begin{array}{l}\text { Nannofossil marl and nannofossil- } \\
\text { bearing clay }\end{array}$ & $\begin{array}{l}18, \text { CC through } 19 \\
(644.5 \text { to } 663.5 \mathrm{~m})\end{array}$ & Late Paleocene \\
\hline $5 \mathrm{a}$ & $\begin{array}{l}\text { Nannofossil-bearing claystone grading } \\
\text { into claystone }\end{array}$ & $\begin{array}{l}20 \text { through } 26 \\
(673 \text { to } 739.5 \mathrm{~m})\end{array}$ & $\begin{array}{l}\text { Late Albian to } \\
\text { early Cenomanian }\end{array}$ \\
\hline $5 \mathrm{~b}$ & $\begin{array}{l}\text { Calcareous silty claystone, nannofossil- } \\
\text { bearing claystone, siltstones, and sand- } \\
\text { stones }\end{array}$ & $\begin{array}{l}27 \text { through } 51 \\
(740 \text { to } 1176.5 \mathrm{~m})\end{array}$ & $\begin{array}{l}\text { Albian to not older } \\
\text { than late Valanginian }\end{array}$ \\
\hline
\end{tabular}

The silty nannofossil marl of subunit $2 b$ is dark greenish gray (5Y4/1) and composed of abundant nannofossils, and clay, common quartz and detrital carbonate, rare feldspars, heavy minerals, and carbonate rhombs, and traces of zeolites. Laminae and thin beds (up to $5 \mathrm{~cm}$ thick) of light olive to grayish olive foram-bearing clayey silty sand and clayey silt occur within the marl. The coarser beds have sharp lower contacts and usually have gradational upper contacts with the surrounding marl. Foraminifers are frequently concentrated at the bases of the coarse beds. The silty and sandy beds are composed of moderately sorted, subangular quartz grains, with abundant clay, common foraminifers (with some chambers filled with iron monosulfide [?]) and nannofossils, rare pyrite, and traces of fish debris, plant fragments, mollusk fragments, carbonate rhombs, glauconite, and heavy minerals. The nannofossil ooze of Subunit $2 \mathrm{a}$ is interpreted as a pelagic deposit, based on composition and texture, and the coarser sand and silt beds of Subunit $2 b$ are turbidites. The top of Subunit $2 b$ is the top of the turbidite sequence, and the base is marked by the appearance of siliceous fossils of Unit 3.

Unit 3 is subdivided into three subunits mainly on the occurrence of siliceous fossils, porcellanite and chert, and coarse clastics.

Subunit 3a: Nanno-rad-bearing clay interbedded with nanno-ooze and marl (Core 3, Section 1, $84 \mathrm{~cm}$ through Core 4):

Subunit 3b: Clay with porcellanite, chert and rare beds of fine- to coarse-grained clastics (Cores 5 through 11):

Subunit 3c: Calcareous silty claystone with clastic beds, porcellanite, and chert (Cores 12 through 18):

The nanno-rad-bearing clay of Subunit $3 \mathrm{a}$ is light olive-gray (5Y5/2) and pale green (10G6/1), and composed of abundant clay, common radiolarians, rare sponge spicules, diatoms, quartz, and carbonate rhombs, and traces of fish debris and zeolites. The nannofossil ooze is light greenish gray (5G8/1), composed of abundant nannofossils and rare radiolarians and the rest of the constituents are the same as in the nanno-rad-bearing clay. Thin beds of glauconitic sandy clay, clayey silt, and occasional beds of glauconitic sand with gravel-size material occur within the nanno-rad-bearing clays. The lower contact of these coarser beds with the underlying clay is sharp. The coarse sand and pebbles in the gravelly sand consist of brownish gray claystone, shale, and argillaceous siltstone with rare quartz. The first porcellanite occurs in Core 3, Section 2, and is scattered throughout the subunit. The porcellanite is nodular, brownish gray, and is formed by cementation of the host sediment by opaline silica. The sediments in Subunit $3 \mathrm{a}$ are firm and intensely bioturbated with abundant Zoophycos. The lower boundary of Subunit $3 \mathrm{a}$ is marked by the strong decrease in the abundance of siliceous microfossils.

The clay of Subunit $3 \mathrm{~b}$ is olive-gray $(5 Y 6 / 1)$ and is composed of dominant clay, rare quartz, glauconite, nannofossils, fish debris, and traces of foraminifers and pyrite. Nannofossils are very rare in Cores 9 and 10 . Rare clayey silt and sand beds, 1 to $30 \mathrm{~cm}$ thick, are interbedded with the clay. The contact between sand beds and underlying clay is sharp. The bases of the sand beds are coarse, often with pebbles of brownish mudstone and silty dolomite up to $1 \mathrm{~cm}$ in diameter, the beds become finer upwards, and grade into the overlying clay bed. A slump about $80 \mathrm{~cm}$ thick occurs in Core 9, Section 1. The slump contains fine laminae which may indicate that deposition was by mass flow. Occasional chert nodules and porcellanite occur throughout Subunit 3b. Bioturbation is comparatively rare, and is represented by three main types of burrows: (1) Zoophycos, present only in the upper part of the subunit; (2) more common burrows 1 to $2 \mathrm{~mm}$ in diameter; and (3) burrows about $6 \mathrm{~mm}$ in diameter.

The boundary between Subunits $3 \mathrm{a}$ and $3 \mathrm{~b}$ is placed at the top of the zone characterized by frequent 
turbidites and a slight increase in feldspars and heavy minerals.

Subunit $3 \mathrm{c}$ is composed of the same sediments as Subunit $3 \mathrm{~b}$, but with an increase in abundance of porcellanite and chert, and the addition of abundant coarse clastic beds. The dominant lithology is calcareous silty claystone, grayish olive at the top, grading to dark yellowish brown in the lower part of the subunit. The claystone is composed of abundant clay, common quartz, rare feldspar, glauconite, nannofossils, foraminifers, and carbonate rhombs, and traces of radiolarians, sponge spicules, pyrite, clinoptilolite, and ferro-manganese or iron monosulfide micronodules. Pale blue-green calcareous silty claystone laminae occur in Cores 16 and 17 within the olive nanno-bearing claystone. These laminae contain only traces of calcareous fossils and are less indurated than the surrounding olive claystone.

Beds of coarser clastics, interpreted as turbidites and slump deposits, include silty and sandy claystone, clayey siltstone and sandstone and occasional pebbly coarse sand and gravel. The grains of the coarser clastics are composed mainly of argillaceous rock fragments, glauconite, porcellanite fragments, foraminifers, and occasional mollusk fragments, crinoid fragments, and oolites, all in a mud matrix and cemented by sparry calcite. Porcellanite and nodules of blackish brown chert are very common in the lower part of Subunit 3c, where about six chert horizons occur in every 1.5 meters. The last occurrence of chert is in Core 18, the base of Subunit 3c. Bioturbation is rare throughout the subunit.

Unit 4: Nanno marl and nanno-bearing clay (Sample 18, CC and Core 19):

This unit is not well defined because of poor core recovery. Most of the unit, about $80 \%$ of Core 19 , is a slump. The sediment in Sample 18, CC and a thin bed at the top of Core 19 is very light gray (N7), soft nanno marl, with rare carbonate rhombs and grains. The bulk of Core 19 is composed of greenish gray nanno-bearing clay with thin laminae of light gray nannofossil marl. The green clay consists of common nannofossils, rare zeolites, volcanic glass(?), glauconite, and fish debris. Inclined laminations suggest that $110 \mathrm{~cm}$ of Core 19 represents a single slump. The lower boundary of Unit 4 is marked by the disappearance of light gray marl and by a color change from greenish gray to dark greenish gray at the top of Core 20. Sediments of Unit 4 are soft, whereas the underlying unit is firm.

Unit 5 is subdivided into two subunits on the basis of more nannofossils in Subunit 5a and an increase in the amounts of clastic material in Subunit $5 b$.

Subunit 5a: Nanno-bearing claystone grading downward into claystone (Cores 20 through 26):

Subunit 5b: Calcareous silty claystone, nannobearing claystone, and interbedded argillaceous siltstone, argillaceous sandstone, gravelly claystone, and conglomerate (Cores 27 through 51):

The nanno-bearing claystone of Subunit $5 \mathrm{a}$ is homogeneous dark greenish gray (5G4/1), and contain common nannofossils, rare quartz, carbonate rhombs, and grains, and traces of zeolites, heavy minerals, glauconite, pyrite, and barite. Subunit $5 \mathrm{a}$ is distinguished from overlying Unit 4 by its darker color and an increase in clastic material. The basic lithology changes between Cores 22 and 26 to olive-black $(5 \mathrm{Y} 2 / 1)$ and brownish gray (5YR4/1) claystone with thin beds of a greenish gray $(5 \mathrm{G} 6 / 1)$ claystone. Nannofossils decrease slowly throughout the subunit and, by Cores 25 and 26 , they are very rare to absent. Brownish, opaque to semitranslucent, round palynomorphs(?) are present in trace amounts in Cores 22 through 26. Bioturbation is very rare, and the diameter of burrows are generally less than $1 \mathrm{~mm}$. Barite rosettes occur in Core 20, Section 2, Core 22, Section 3, and a microcrystalline limestone bed underlies the barite in Core 20, Section 2. The base of this subunit is placed at the top of the appearance of coarser clastics in Core 27.

The upper contact of Subunit $5 \mathrm{~b}$ is placed at the first occurrence of argillaceous siltstone in Core 27, Section 1. The dominant lithology is claystone with rare to common nannofossils, rare to abundant silt-size quartz, and rare feldspars, heavy minerals, carbonate rhombs and grains, glauconite, pyrite, palynomorphs, fish remains, and foraminifers. Colors of the claystone vary from olive-black (5Y2/1), grayish green $(5 \mathrm{G} 5 / 2)$, pale green $(10 G 6 / 2)$, to bluish green $(5 B G 5 / 2)$. Several zones within the claystone contain pebbles, up to $3 \mathrm{~cm}$ in cross-section, floating in a clay matrix.

The coarser components of Subunit $5 \mathrm{~b}$ consist of reddish, brownish, and greenish siltstone, mudstone, calcareous siltstone, limestone fragments, and rounded grains of quartz, feldspar, glauconite, fragments of mollusks and fish, and rare oolites (?), all cemented by ferroan calcite. The coarser clastic interbeds frequently show graded bedding, laminations, and sharp basal contacts with occasional scour features. The first sandstone bed occurs in Core 32. Nannofossils increase in abundance below Core 33. Thick interbeds ( 1 to 20 $\mathrm{cm}$ ) of calcareous argillaceous siltstone occur below Core 35 . Sandstone is very rare. The siltstones are finely laminated, and often have contorted bedding, low angle cross-bedding, and current ripples with amplitudes on the order of $1 \mathrm{~cm}$. Both upper and lower contacts of the siltstone with surrounding claystone are sharp. Cores 40 through 51 show a further decrease in grain size, with thin beds of reddish brown claystone, containing organic matter and pyrite interbedded with olive-gray $(5 \mathrm{Y} 3 / 2)$ and dark greenish gray $(5 \mathrm{Y} 4 / 1)$ nannofossilbearing claystone, and marlstone, and pale yellowish brown (5YR6/1) calcareous siltstone.

\section{Summary}

Site 370 is located in a 400 -meter abyssal depression between the Moroccan continental margin on the east, and a broad elevation to the west. The existence of this depression may help to explain some of the sedimentary features observed. Pelagic sediments are present only in the Pleistocene part of the section. The major lithologies throughout the remainder of the section are hemipelagic nannofossil-bearing clay and marl, with variable amounts of coarse clastics, siliceous biogenic material, chert, and porcellanite. The entire sequence 
shows a very low degree of bioturbation. Slumping, as evidenced by contorted bedding, is also common.

The sedimentary sequence from middle Miocene to the Lower Cretaceous (106 to $1176.5 \mathrm{~m}$ ) is probably a submarine fan (see Gardner et al., this volume), with minor thin beds of coarse clastics in a predominantly clay section. The dominant coarse-clastic lithologies are silty, sandy, and gravelly claystone and mudstone. We expected to find some features indicating the presence of deep submarine channels, but the thickest bed of coarse clastics found in the entire sequence is only about 1 meter thick.

Two intervals of maximum coarse clastic deposition occur: one in the Neocomian and another in the lower and middle Eocene. The Eocene coarse clastics are composed mainly of clasts of argillaceous and calcareous sediment with some glauconite, foraminifers, mollusk fragments, and occasional oolites. The Neocomian coarse clastics are mainly composed of a mixture of sand-size quartz and carbonate intraclasts.

\section{GEOCHEMICAL MEASUREMENTS}

The analytical techniques used in the geochemical determinations are described in the Introduction to this volume.

\section{Organic Carbon and C/N Ratios}

Samples were taken at regular intervals throughout the entire hole in order to establish a good profile on organic carbon content. Organic carbon values ranged from less than $0.1 \%$ to $6.1 \%$. C/N ratios varied from 3.2 to 23.2. $\mathrm{C} / \mathrm{N}$ was high; however, some samples having $1 \%$ to $2 \% \mathrm{C}$ had higher $\mathrm{C} / \mathrm{N}$ ratios than samples with $3 \%$ to $6 \%$ C. Complete results are given in Table 3 .

\section{Interstitial Gas}

No ethane was encountered at this site. Methane was generally low; however, this may be attributed to dilution by air at the time of sampling. Complete results are in Table 4.

\section{Carbonate Analyses}

Carbonate analyses using the carbonate bomb method are given in Table 5. No relationship is apparent between percent $\mathrm{CaCO}_{3}$ and percent organic carbon. At previous sites where carbonate was high, organic carbon was low, and vice versa.

\section{Interstitial Water}

Calcium, salinity, and chlorinity increase steadily with depth, whereas alkalinity decreases. The maximum salinity was $59.4 \%$ in Core 24 , Section 3 $(800 \mathrm{~m})$. Results are given in Table 6 and Figure 5.

\section{PHYSICAL PROPERTIES}

Tabulations of all physical property measurements are in Trabant (this volume).

\section{Bulk Properties}

Bulk property measurements were made for bulk density, water content, void ratio, porosity, and specific
TABLE 3

Carbon and Nitrogen Analyses for Site $\mathbf{3 7 0}$

\begin{tabular}{|c|c|c|c|c|c|c|}
\hline \multirow{2}{*}{$\begin{array}{c}\text { Sample } \\
\text { (Interval in } \mathrm{cm} \text { ) }\end{array}$} & \multirow{2}{*}{$\begin{array}{l}\text { Depth } \\
\text { (m) }\end{array}$} & \multicolumn{2}{|c|}{$\begin{array}{c}\text { \% Organic C } \\
\text { (total dry wt. basis) }\end{array}$} & \multicolumn{2}{|c|}{$\begin{array}{c}\mathrm{C} / \mathrm{N} \\
\text { (atomic ratio) }\end{array}$} & \multirow[b]{2}{*}{ Remarks } \\
\hline & & $x$ & SD & $x$ & SD & \\
\hline $1-1,94-95$ & 8 & 0.601 & 0.057 & 9.7 & 0.5 & \\
\hline $2-2,60-61$ & 110 & 0.076 & 0.001 & 3.4 & 0.2 & \\
\hline $3-1,96-97$ & 210 & 0.697 & 0.001 & 11.1 & 0.1 & \\
\hline $5-5,70-71$ & 325 & 0.162 & 0.024 & 3.5 & 0.4 & \\
\hline $6-2,40-41$ & 430 & 0.527 & 0.000 & 10.3 & 0.02 & \\
\hline $7-2,80-81$ & 450 & 0.389 & 0.100 & 6.2 & 0.1 & \\
\hline $8-2,40-41$ & 470 & 0.730 & 0.013 & 15.7 & 0.1 & \\
\hline $9-1,90-91$ & 490 & 0.684 & 0.007 & 12.3 & 0.8 & \\
\hline $10-2,24-25$ & 510 & 1.477 & 0.008 & 20.0 & 0.7 & \\
\hline $143,54-55$ & 575 & 1.119 & 0.078 & 18.7 & 0.6 & \\
\hline $16-2,37-38$ & 610 & 0.323 & 0.005 & 7.2 & 0.1 & \\
\hline $17-2,44-45$ & 620 & 3.931 & 0.038 & 23.1 & 0.01 & \\
\hline $18-1,72-73$ & 640 & 1.986 & 0.063 & 22.1 & 0.1 & \\
\hline $22-2,130$ & 700 & 1.269 & 0.068 & 18.1 & 0.9 & \\
\hline $22-2,146-150$ & 700 & 1.190 & - & - & - & Leco-Shell \\
\hline $21-2,60-61$ & 690 & 0.617 & 0.006 & 13.0 & 0.4 & \\
\hline $23-2,81-83$ & 710 & 0.400 & 0.043 & 12.7 & 1.8 & \\
\hline $243,88-89$ & 715 & 0.068 & 0.008 & 4.6 & 0.2 & \\
\hline $26-3,92-93$ & 735 & 0.391 & 0.023 & 14.9 & 0.2 & \\
\hline $27-1,130$ & 755 & 0.083 & 0.100 & 5.6 & 0.3 & \\
\hline $28-4,136-139$ & 775 & 1.641 & 0.023 & 19.3 & 1.4 & \\
\hline $30-4,113-114$ & 810 & 1.299 & 0.033 & 19.6 & 0.1 & \\
\hline $31-3,128-129$ & 830 & 2.500 & 0.009 & 18.8 & 0.2 & \\
\hline $32-4,11-12$ & 840 & 1.333 & 0.062 & 17.9 & 1.0 & \\
\hline 344,130 & 880 & 1.397 & 0.036 & 17.8 & 0.2 & \\
\hline $34-4,146-150$ & 880 & 1.770 & - & - & - & Leco-Shell \\
\hline $35-5,3-4$ & 890 & 6.068 & 0.116 & 20.4 & 0.4 & \\
\hline $38-4,106-107$ & 945 & 1.964 & 0.014 & 18.6 & 0.8 & \\
\hline 393,150 & 955 & 0.312 & 0.008 & 11.9 & 0.2 & \\
\hline $46-5,20-21$ & & 0.759 & - & 16.7 & - & TAMU \\
\hline $47-2,50-51$ & & 0.456 & - & 11.3 & - & TAMU \\
\hline
\end{tabular}

TABLE 4

Interstitial Gas Analyses for Site $\mathbf{3 7 0}$

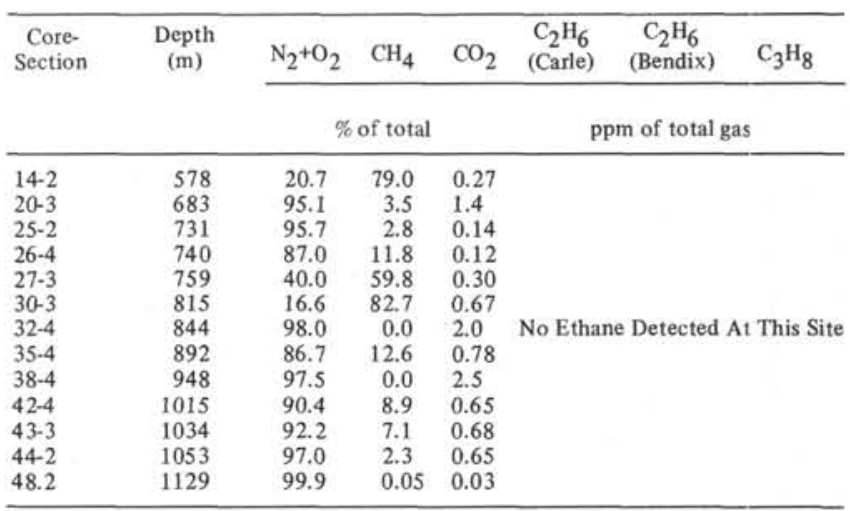

gravity. Several irregularities are apparent in the general trend of porosity with depth (Figure 6). A notable decrease in porosity, to values below $46 \%$, occurs at about 460 meters and correlates with both an increase in sonic velocity and the presence of a strong seismic reflector. This decrease in porosity occurs within lithologic Subunit 3b (calcareous silty clay with porcellanite) and appears due to an increase in cementation within the silty clays as well as the presence of porcellanite. Both of these factors are indicative of diagenetic cementation. A net increase in porosity values is seen within lithologic Subunit 3c (calcareous silty clay with silt, sand, porcellanite, and chert). This could reflect a decrease in the effects of cementation as well as an influx of unsorted sediments 
TABLE 5

Carbonate Analyses Using Carbonate Bomb Method for Site 370

\begin{tabular}{|c|c|c|c|}
\hline $\begin{array}{c}\text { Sample } \\
\text { (Interval in } \mathrm{cm} \text { ) }\end{array}$ & $\begin{array}{c}\text { Depth } \\
\text { Subbottom } \\
\text { (m) }\end{array}$ & $\% \mathrm{Ca} \mathrm{CO} 3$ & Lithology \\
\hline $1-3,86-87$ & 6 & 46 & Clayey nanno marl \\
\hline $2-2,75-76$ & 110 & 54 & Silty nanno marl \\
\hline $3-1,64-65$ & 210 & 23 & Nanno ooze \\
\hline $3-1,109-110$ & 210 & 60 & Nanno rad-bearing clay \\
\hline $4-3,49-50$ & 225 & 24 & Silty clay \\
\hline $5-3,87-88$ & 330 & 24 & Silty claystone \\
\hline $6-2,73-74$ & 430 & 6 & Claystone \\
\hline $8-2,82-83$ & 470 & 19 & Claystone \\
\hline $9-1,122-123$ & 490 & 13 & Claystone \\
\hline $10-2,50-51$ & 510 & 15 & Silty clay stone \\
\hline $12-1,81-82$ & 545 & 21 & Claystone \\
\hline $13-2,75-76$ & 555 & 9 & Silty claystone \\
\hline $13-2,101-102$ & 555 & 70 & Limestone \\
\hline $14-1,98-99$ & 575 & 20 & Silty claystone \\
\hline $15-3,121-122$ & 595 & 47 & Marlstone \\
\hline $17-2,14-15$ & 625 & 30 & Silty clay \\
\hline $19-1,88-89$ & 660 & 32 & Nanno marl \\
\hline $20-2,72-73$ & 680 & 11 & Nanno-bearing claystone \\
\hline $21-2,26-27$ & 690 & 15 & Nanno-bearing claystone \\
\hline $22-3,55-56$ & 700 & 14 & Nanno-bearing shale \\
\hline $23-3,85-86$ & 710 & 8 & Nanno-bearing shale \\
\hline $24-3,85-86$ & 720 & 9 & Nanno-bearing shale \\
\hline $25-2,65-66$ & 730 & 3 & Shale \\
\hline $26-3,65-66$ & 740 & 23 & Shale \\
\hline $27-3,92-93$ & 755 & 5 & Silty claystone \\
\hline $28-3,51-52$ & 775 & 0 & Silty clay \\
\hline $30-3,70-71$ & 795 & 0 & Silty clay \\
\hline $42-4,31-32$ & 1015 & 23 & Nanno-bearing marlstone \\
\hline $42-4,38-39$ & 1015 & 0 & Claystone \\
\hline
\end{tabular}

deposited by turbidity flows and slumps. Porosities decrease linearly below a depth of approximately 700 meters, with very low values (less than $30 \%$ ) occurring within the frequent sandstone layers of lithologic Unit 5 below 900 meters.

\section{Shear Strengths}

Shear strength data could be taken only for the few intervals cored above a depth of 326 meters. Below this depth all values are above $5.0 \mathrm{~km} / \mathrm{cm}^{2}$, the limit of onboard shear strength apparatuses. These values are tabulated in Trabant (this volume).

\section{Acoustic Velocities}

Acoustic velocity data indicate a linear increase in velocity down to about 460 meters, below which a notable increase occurs, associated with the low porosity values discussed above (Figure 7). This zone of higher velocity is marked by a prominent seismic reflector which may be correlated with the velocity change at approximately 475 meters. Acoustic velocities decrease below 475 meters and do not appear to increase until a depth of approximately 825 meters. The clay, which is the major lithologic component, has velocities between 1.56 and $2.69 \mathrm{~km} / \mathrm{sec}$. They are cohesive but become increasingly more cemented below a depth of 250 meters which produces velocities which reach values of over $5.5 \mathrm{~km} / \mathrm{sec}$ within the fine-grained sandstones. Acoustic anisotropy is quite noticeable, although not always in the same direction. In general, vertically measured velocities are lower than those measured horizontally.

\section{Summary}

Physical properties data indicate two anomalous zones, one at 500 meters and another at 775 meters. These two zones are most likely the result of diagenetic effects of cementation and rapid sedimentation caused by turbidity flow and slumps. These features are possibly responsible for two prominent seismic reflectors. Low velocities and high porosities below 670 meters may be associated with a series of Paleocene unconformities.

\section{BIOSTRATIGRAPHIC SUMMARY}

The sediments at Site 370 range in age from Pleistocene to Early Cretaceous. Planktonic foraminifers are abundant and well preserved only in the Pleistocene, Paleocene, and lower Cenomanian sediments. They are less abundant to absent in the Miocene, Oligocene, Eocene, and Lower Cretaceous, and very often poorly preserved; thus they allow only an approximate age determination. Benthic foraminifers are less frequent than the planktonics, but they play an important role for age determination in the

TABLE 6

Summary of Interstitial Water Analyses for Site 370

\begin{tabular}{cccccccc}
\hline $\begin{array}{c}\text { Sample } \\
\text { (Interval in cm) }\end{array}$ & $\begin{array}{c}\text { Subdepth } \\
(\mathrm{m})\end{array}$ & $p \mathrm{H}$ & $\begin{array}{c}\text { Alkalinity } \\
(\mathrm{meq} / \mathrm{kg})\end{array}$ & $\begin{array}{c}\text { Salinity } \\
\left.\left({ }^{\circ}\right)^{\circ}\right)\end{array}$ & $\begin{array}{c}\mathrm{Ca}^{++} \\
(\mathrm{mmoles} / \mathrm{l})\end{array}$ & $\begin{array}{c}\mathrm{Mg}^{++} \\
(\mathrm{mmoles} / \mathrm{l})\end{array}$ & $\begin{array}{c}\mathrm{Cl}^{-} \\
\left({ }^{\circ}{ }^{\circ}\right)\end{array}$ \\
\hline $1-4,144-150$ & 6.0 & 7.50 & 2.47 & 35.2 & 10.45 & 51.54 & 17.41 \\
$2-1,144-150$ & 104.5 & 7.21 & 2.41 & 36.0 & 13.31 & 42.26 & 20.59 \\
$3-1,144-150$ & 209.0 & 7.28 & 2.46 & 36.6 & 16.12 & 36.39 & 21.87 \\
$5-5,144-150$ & 329.0 & 8.06 & 1.34 & 39.9 & 23.76 & 29.18 & 24.44 \\
$6-2,144-150$ & 429.0 & - & - & 41.8 & 25.11 & 30.61 & 25.32 \\
$12-2,144-150$ & 543.0 & - & 1.26 & 47.6 & 30.43 & 39.29 & 29.23 \\
$17-2,144-150$ & 620.0 & 7.17 & 0.37 & 49.2 & 31.06 & 44.20 & 30.44 \\
$20-2,144-150$ & 680.0 & 7.83 & 0.18 & 49.8 & 38.39 & 37.82 & 30.98 \\
$25-1,144-150$ & 725.0 & 7.67 & 0.23 & 50.9 & 39.32 & 40.18 & 30.98 \\
$30-2,144-150$ & 810.0 & 7.82 & 0.51 & 58.6 & 52.31 & 43.38 & 36.45 \\
$34-3,144-150$ & 880.0 & 8.02 & 0.22 & 59.4 & 51.28 & 41.19 & 36.18 \\
$38-4,144-150$ & 945.0 & 7.79 & 0.18 & 54.7 & 43.76 & 31.94 & 33.28 \\
$41-4,144-150$ & 995.0 & 6.62 & 0.12 & 56.7 & 46.40 & 33.46 & 33.92 \\
$44-144-150$ & 1050.0 & - & 0.12 & 56.7 & 45.27 & 30.72 & 32.96 \\
$47-1,144-150$ & 1105.0 & 7.53 & 0.12 & 59.1 & 47.96 & 31.39 & 36.72 \\
\hline
\end{tabular}



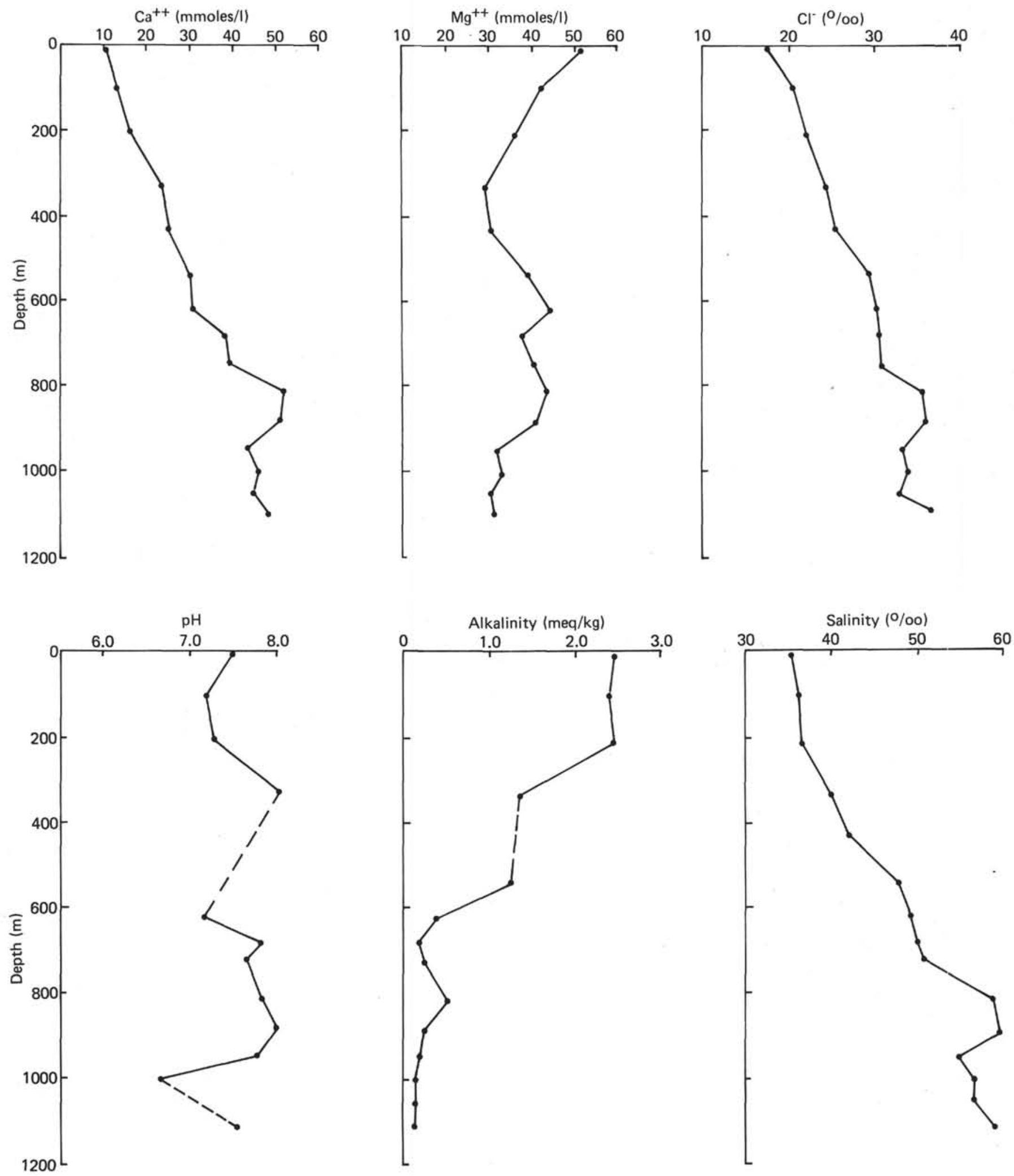

Figure 5. Plots of interstitial water analyses for Site 370.

Lower Cretaceous. The abundance of calcareous nannoplankton is high in Pliocene, upper Miocene, Paleocene, and Cretaceous sediments, however, in the other intervals this group is generally less abundant, and ares absent from Cores 15, 26, and 29.

Radiolarians are present only in the middle Eocene through middle Miocene (cores 3 through 12). Preservation is good in the Miocene, moderate in the Oligocene, and poor in the Eocene. No identifiable radiolarians were observed in cores below Core 12 . 


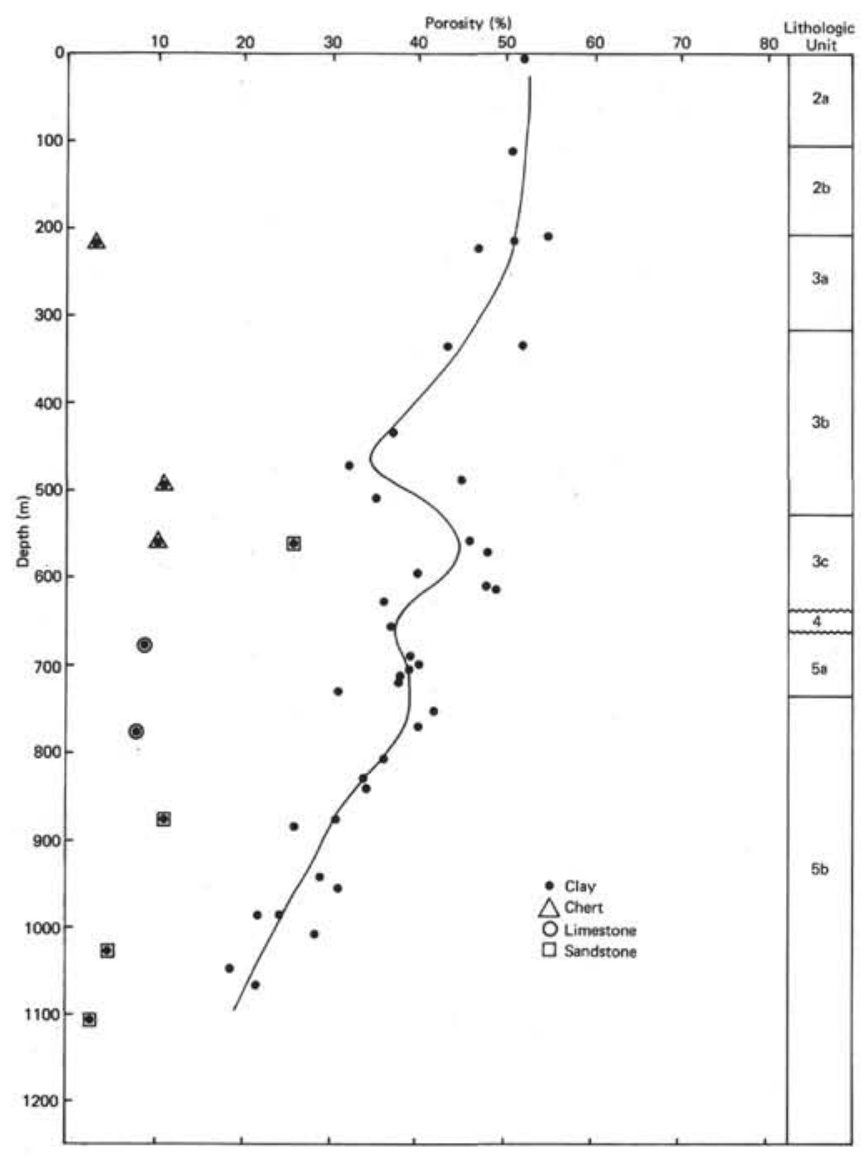

Figure 6. Plot of porosity versus depth for Site 370.

Cores 1 through 3 are characterized by mixed assemblages of all three principal microfossil groups. Admixtures of Miocene age are especially common. The microfossils in this unit show no signs of dissolution. Because of extensive mixing, the age of the sediments in this unit is based on the youngest identifiable forms.

\section{Foraminifers}

The biostratigraphy of the uppermost 430 meters of the section is poorly known because of spot coring. The intervals between the cored sections from 430 meters to the final depth of 1176.5 meters are small, and therefore a more detailed stratigraphic outline is given for this interval.

\section{Cenozoic}

Cores 1 through 3 are characterized by mixed foraminiferal assemblages of different ages and paleoenvironments. The ages therefore are determined by the findings of the youngest forms. Core 1 is Pleistocene in age as determined by the presence of Globorotalia truncatulinoides, G. hessi, G. inflata, Globigerina rubescens (pink), and Globigerinoides ruber (pink). The upper Miocene (or younger) is represented in Core 2 by Globorotalia dutertrei, G. humerosa, G. acostaensis, Globigerina nepenthes, and Globigerinoides extremus. The upper part of middle Miocene (or younger) is indicated in Core 3 by Globigerina druryi, $G$. nepenthes, Globorotalia continuosa. G. siakensis,

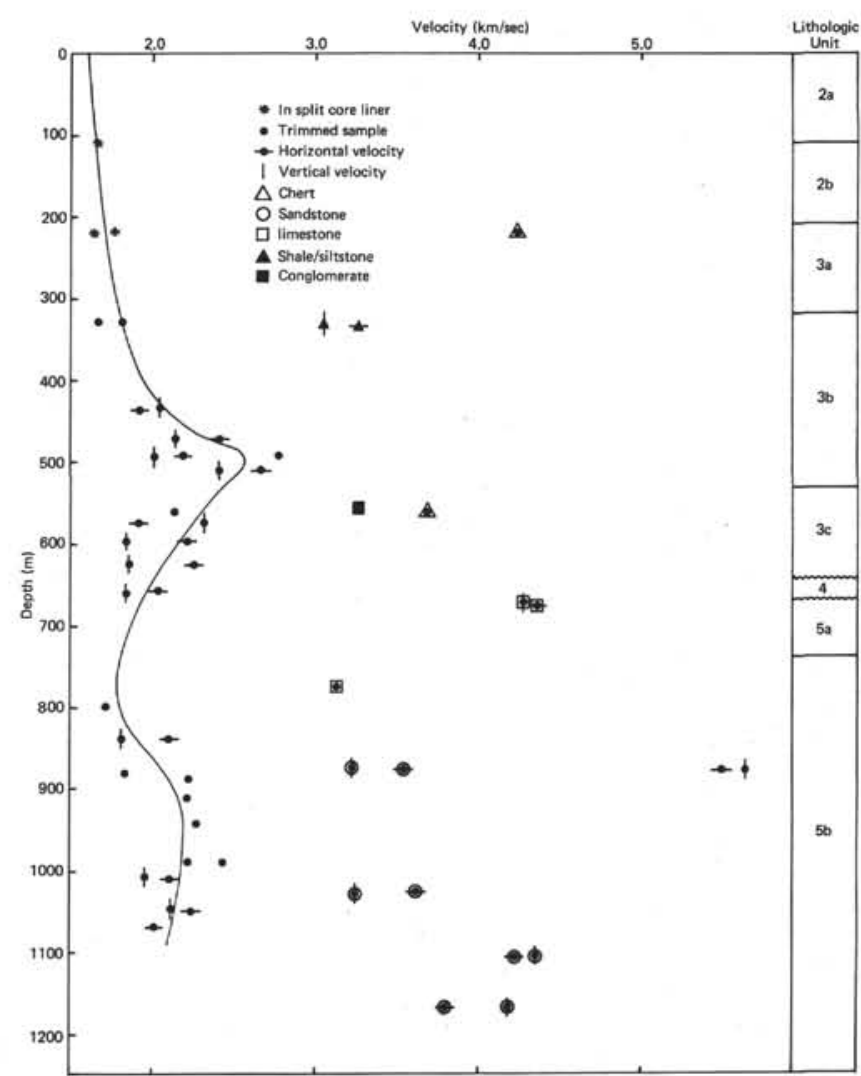

Figure 7. Plot of acoustic velocity versus depth for Site 370.

Orbulina suturalis, Globigerinoides bisphaericus. High abundance and good preservation occur in these cores and are probably associated with rapid burial of the foraminiferal shells. The benthic component of the foraminiferal fauna is less abundant, but contains representatives of different facies, including shallowwater inhabitants such as Ammonia beccarii. The lower Miocene (Sample 4, CC) is represented by Globorotalia siakensis, Globigerina venezuelana, Globigerinita unicava, and Globoquadrina dehiscens. The Globorotalia opima opima Zone of the upper Oligocene occurs in Core 5. Abundance and preservation of benthic species vary greatly in Core 6 . They are common and well preserved in upper Oligocene sediments but they are missing in lower Miocene and upper Eocene sediments. Planktonic and benthic foraminifers are few to rare and mostly moderately preserved in Cores 7 through 18. The specific composition of middle Eocene planktonic foraminifers is poor and prevents a precise zonal subdivision of Cores 7 through 12. The assemblage in Cores 7 and 8 indicate the upper part of middle Eocene. Cores 9 through 12 contain Globigerina boweri, G. senni, Acarinina bullbrooki, A. broedermanni, A. pentacamerata, indicating an age of lower part of middle Eocene. The lower Eocene (Cores 13 through 18 ) is represented by its upper part Globorotalia palmerae-Globorotalia aragonensis zones. A hiatus occurs within Sample 18, CC corresponding to the lower part of the lower Eocene (Globorotalia subbotinae/G. formosa formosa zones).

Paleocene sediments of Sample 18, CC through Core 19 contain common foraminifers with moderate 
preservation. Benthic foraminifers are common to few and diverse. Two zones are differentiated within the upper Paleocene: Core 18 has the Globorotalia velascoensis Zone and Core 19 has the Globorotalia pseudomenardii Zone. The middle Paleocene (Sample $19,(C)$ ) is represented by the upper part of the Globorotalia pusilla Zone. There is a pronounced hiatus between the lower Paleocene and the lower Cenomanian.

\section{Mesozoic}

A diverse and well-preserved assemblage of lower Cenomanian planktonic foraminifers occurs in Cores 20 through 26 . The assemblage belongs to the Rotalipora appeninica Zone of the lower Cenomanian. Both calcareous and agglutinated species of benthic foraminifer are rare to few, but their generic composition is relatively diverse. Calcisphaerulids are also present. The main paleontological features of Cores 27 through 32 are planktonic foraminifers, benthic foraminifers, fish debris, and Calcisphaerulids. The amount of planktonic foraminifera is variable, some samples are extremely rich (i.e., Cores 36 and 37) whereas others are barren of planktonic foraminifers (i.e., Samples 27, CC and 28, CC) or contain only a few (i.e., Cores 29, 30, 33 through 35). Two stratigraphic subdivisions can be made. The Albian to upper Aptian is present in Cores 29 through 30 with Hedbergella infracretacea, $H$. globigerinelloides, $H$. sp. Globigerinelloides gyroidinaeformis, and Heterohelicids. The lower Aptian? to Hauterivian? occurs in Cores 33 through 37 with Hedbergella aff. infracretacea, $H$. aff. simplicissima, $H$. aff. ultramicra, and some primitive species of Hedbergella and Gubkinella. The benthic foraminiferal fauna consists mainly of agglutinated and small-sized calcareous forms. Planktonic foraminifers are absent in Cores 38 through 51 with one exception; Sample 50, CC. All samples examined contain fish debris and rare benthic foraminifers with poor preservation. The benthic foraminifers in Core 44 are common and the preservation is moderate. The benthic foraminifers observed include: Dorothia prehauteriviana, some representatives of Lagenids (Lenticulina, Astacolus, Dentalina, Nodosaria, Marginulina, Tristix, Frondicularia, and Saracenaria), Spirillina and some species of agglutinated forms. Sample 50, CC contains a few pyritic casts of "Globigerina" cf. oxfordiana; a species which has been reported from the Oxfordian to lower Neocomian.

\section{Calcareous Nannoplankton}

The preservation of coccoliths in the upper part of Site 370 is generally poor to moderate and the abundances are few to common. The lower part shows generally moderate to good preservation and the abundances range from common to abundant.

\section{Cenozoic}

Core 1 contains the upper Pliocene Discoaster tamalis Subzone. Lower middle Miocene assemblages indicated by Cyclococcolithina macintyrei, Discoaster rxilis, and Sphenolithus heteromorphus occur in Cores 2 and 3 . The coccoliths of Core 4 are poorly diagnostic. Upper Oligocene floras were recovered in Core 5 which contains Sphenolithus ciperoensis and in Core 6 which contains rare $S$. distentus. Cores 7 through 14 contain Reticulofenestra umbilica and Chiasmolithus solitus, and belong to the middle Eocene Reticulofenestra umbilica Zone. Discoaster lodoensis and Discoaster sp. cf. D. sublodoensis (5- and 6-rayed) occur in Cores 16 to 18 which correlate with the upper lower Eocene. The Discoaster multiradiatus Zone was recognized in Sample 18, CC. Three coccolith zones were recognized in Core 19: Heliolithus kleinpellii Zone; Fasciculithus tympaniformis Zone with Ericsonia supertusa and Chiasmolithus bidens, and a level which is not older than the Cruciplacolithus tenuis Zone.

\section{Mesozoic}

The Cretaceous sediments in Samples 20-1, 70-71 cm through $51, \mathrm{CC}$ can be divided into three intervals. Core 20 through Sample 26-3, 80-81 cm contain the Eiffellithus turriseiffeli Zone which limits the age to not older than late Albian. The upper boundary is probably Turonian, based on the occurrence of Parhabdolithus asper, but the typical species for this age is missing. The second interval is the Parhabdolithus angustus Zone (late Aptian to early Albian), where Parhabdolithus angustus and Lithastrinus floralis were observed in Cores 28 through 31 and Chiastozygus litterarius Zone in Core 32; early Aptian in age. A Neocomian assemblage of coccoliths comprises the third interval (Cores 33, CC to 51). This 400-meter section of Neocomian is divided into three intervals:

a) Barremian with Nannoconus colomi in Core 33 through Sample 34, CC;

b) Late Hauterivian in Cores 35 , Section $3,70-71 \mathrm{~cm}$ to 38 , Section 1, 91-92 $\mathrm{cm}$ with Cruciellipsis cuvillieri (upper level) and Parhabdolithus infinitus (lower level); and

c) Late Valanginian to early Hauterivian in Sample 38 , CC through Core 51. This interval has Parhabdolithus dietzmannii (lower level), Parhabdolithus asper, Cruciellipsis cuvillieri, and Lithraphidites carniolensis, but Parhabdolithus infinitus is missing.

\section{Radiolarians}

Site 370 contains identifiable radiolarians only within sediments of middle Eocene through middle Miocene (Cores 3 through 12) age. Early Cenozoic sediments (Paleocene and lower Eocene) contain poorly preserved radiolarian tests; almost all of the silica has been remobilized into chert, with only rare fragments remaining which resemble the original morphologies of the radiolarian skeletal material. Mesozoic sediments appear devoid of biogenous silica, or else the silica has been totally replaced.

\section{Cenozoic}

Radiolaria are absent in Cores 1 and 2. Core 3 contains sediments of probable middle Miocene age. A diverse and well-preserved radiolarian assemblage is present, but assignment of a precise zonal age is difficult because of extensive mixing of taxa whose 
stratigraphic ranges do not overlap, but extend throughout the entire lower and middle Miocene. This apparent mixing may be either a result of processes of erosion and redeposition, or may be an artifact produced if sediment were allowed to enter the empty core barrel inadvertently within a "washed" interval. In either case the faunal assemblages in the Miocene cores at this site have no biostratigraphic significance, and the age assignments are only approximate. Core 3 is assigned to the Stichocorys wolffii Zone. Numerous Miocene species are present, including one specimen each of Calocycletta costata and Dorcadospyris alata. These two middle Miocene forms are presumed to be down-hole contaminants because of their low abundance, although the possibility cannot be ruled out that they are in place. Core 4 contains abundant diatoms, with a few well-preserved radiolarians which suggest a lower Miocene age (Stichocorys delmontensis Zone). The calcite-free coarse fraction in Core 5 is principally sponge spicules but rare radiolarians of upper Oligocene age (Dorgadospyris ateuchus Zone) are present. Cores 6 through 9 contain very poorly preserved radiolarian fragments of middle to late Eocene age, including the genera Theocampe, Lithocyclia, and Stylosphaera. Core 10 belongs to the middle Eocene Theocampe triacantha Zone. Core 12 is of earliest middle Eocene age, based on rare specimens of Theocampe amphora and one specimen resembling the early morphotype of Theocampe mongolfieri. Numerous poorly preserved spongidiscids were also observed in Core 12, but none were sufficiently preserved for exact identification. No identifiable radiolarians were observed in core-catcher samples from below Core 12. The Cenozoic silica accumulation record closely resembles that of the other Leg 41 sites and the Leg 14 sites: rare to common siliceous microfossils in middle Eocene to middle Miocene sediments; chert and poorly preserved radiolarian debris in Paleocene and lower Eocene sediments; and no biogenous silica in upper Miocene through upper Pleistocene sediments.

\section{Conclusions}

The following interpretation can be drawn from the biostratigraphic record at Site 370 :

1) There is a comparatively low abundance of calcareous microfossils, except for the Cenomanian, which indicates deep-water conditions. Many species of calcareous fossils, but particularly the foraminifers, are partially dissolved.

2) Substantial hiatuses are present in Sample 18, CC, where two lower Eocene foraminiferal zones are absent. Another unconformity exists between the lower Cenomanian and Paleocene, where practically the entire Upper Cretaceous and lower Paleocene are missing. Other significant gaps may be present in the sparsely cored interval of Eocene through Pleistocene age, but these gaps, if present, cannot be resolved with the limited number of cores available.

3) Pleistocene turbidites contain a mixture of planktonic foraminifers of different ages and the benthic foraminifers represent different paleoenvironments. Tertiary and Cretaceous turbidites contain no mixed assemblages of the planktonic and of the benthic foraminiferal faunas.

\section{ACCUMULATION RATES}

The calculations of accumulation rates are based on the stratigraphy by planktonic foraminifers, nannofossils, and radiolarians and on the absolute age scales mentioned in previous site chapters $(366,367)$. Due to large uncored intervals, and due to turbidites in the few cores drilled, relevant accumulation rates cannot be given for the topmost 450 meters of the hole, i.e., Pleistocene to latest Miocene. No attempt has been made to correct the accumulation rates for the effects of compaction.

Accumulation rates during nearly the entire Eocene are as high as $35 \mathrm{~m} / \mathrm{m} . \mathrm{y}$. (Figure 8). The mean accumulation rate for the middle Paleocene is as low as about $4 \mathrm{~m} / \mathrm{m} . y$. There is a hiatus between Samples 19, $\mathrm{CC}$ and 20, CC, representing a time interval from Paleocene to upper Cenomanian of about 35 m.y. The accumulation rates during the Cenomanian were at least $18 \mathrm{~m} / \mathrm{m} . \mathrm{y}$., because the top of the Cenomanian is missing. There is a decrease in mean accumulation rates during the Aptian to Albian time interval to $12 \mathrm{~m} / \mathrm{m} . y$., whereas the Neocomian mean accumulation rates were much higher. They cannot be accurately determined in the absence of any significant change in age in the lowermost part of the hole. Therefore the rate of 25 $\mathrm{m} / \mathrm{m} . \mathrm{y}$. indicated on the figure is a minimum.

\section{CORRELATION OF SEISMIC REFLECTION PROFILES WITH DRILLING RESULTS}

The correlation of the seismic data with the drilling results is established from a combined use of the Lamont-Doherty Vema 30 reference profile (see Figure 2) and the Glomar Challenger profile recorded while approaching the site (see Figure 4). The Glomar Challenger profile was recorded at higher frequency settings than the Lamont one and shows a better definition in the upper layers. The penetration, however, does not exceed about $0.9 \mathrm{sec}$, whereas it reaches about $3 \mathrm{sec}$ on the Lamont profile. On the other hand, because of the very low frequency used on the latter, the upper section is very difficult to decipher. Figure 9 integrates the data of both profiles.

The acoustic section at the site consists of the following reflectors: a double reflector at 0.2 and 0.3 $\mathrm{sec}$ below the sea floor, another double reflector at 0.5 and $0.6 \mathrm{sec}$, a relatively sharp but faint reflector at 0.85 sec, and a series of 4 to 5 deep, badly defined reflectors corresponding to layers that could not be reached by drilling. The uppermost of these deep reflectors, at 1.2 $\mathrm{sec}$ is believed to be reflector $\mathrm{C}$, one of the primary targets for Site 370 . The lowermost very faint reflector at about $3.0 \mathrm{sec}$ exhibits a rough topography and is tentatively interpreted as oceanic basement.

The first two reflectors, at 0.2 and $0.3 \mathrm{sec}$, respectively, fall into unsampled intervals. If interval velocities of about 1.6 to $1.7 \mathrm{~km} / \mathrm{sec}$ are assumed for the overlying sediments, the first reflector should correspond with layers lying at about 160 to 170 meters. If we apply velocities of about 1.65 to $1.8 \mathrm{~km} / \mathrm{sec}$ for the sediments between the sea floor and the second 


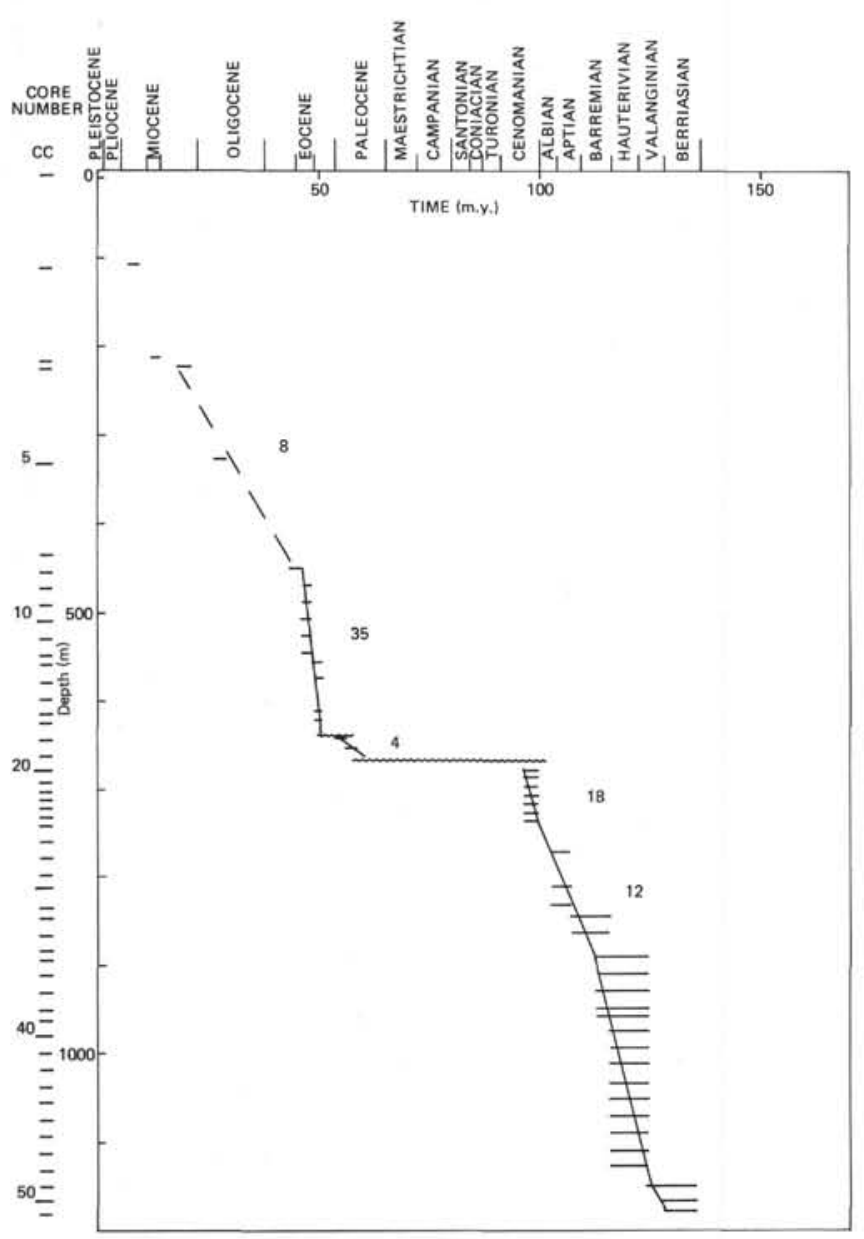

Figure 8. Plot of average accumulation rates for Site 370 .

reflector, then the latter should correspond with sediments at 250 to 270 meters below the bottom.

The third reflector, at $0.5 \mathrm{sec}$, correlates well with an abrupt change in sound velocities and porosities recorded at about 460 meters below the sea floor. At the same level (Figures 6 and 7), an increase in porcellanite content and the occurrence of several cemented conglomerate layers might also be correlated with the reflector. This correlation implies average interval velocities of about $1.84 \mathrm{~km} / \mathrm{sec}$ for the overlying sediments (from the sea floor) which are in good agreement with the values measured on samples.

The fourth reflector, at $0.6 \mathrm{sec}$, correlates with a substantial increase in chert and porcellanite recorded at about 580 meters subbottom. Such a correlation implies velocities of $1.93 \mathrm{~km} / \mathrm{sec}$ for the layers between the fourth and the third reflector. Again these values are in good agreement with the one measured on the samples.

The last reflector present in the interval sampled at this site lies at $0.85 \mathrm{sec}$. It appears to correlate with the youngest occurrence of well-cemented, several centimeters thick, sandstone and siltstone beds. The first of these beds are recorded at about 835 meters but the thickest one lies at about 860 meters below the sea floor. Therefore the correlation cannot be established too precisely. Such a correlation gives interval average velocities of 1.96 to $2.02 \mathrm{~km} / \mathrm{sec}$ for the complete overlying section and 2.04 to $2.24 \mathrm{~km} / \mathrm{sec}$ for the interval between the fourth reflector and this one, which is in acceptable agreement with the measured values if we consider that this interval exhibits several values below $2.0 \mathrm{~km} / \mathrm{sec}$ (Figure 7).

The reflector at about $1.2 \mathrm{sec}$ was not reached and might correspond with layers as deep as 1260 meters if a velocity of $2.3 \mathrm{~km} / \mathrm{sec}$ is applied to the interval between the fifth reflector and this lowermost one.

\section{SUMMARY AND CONCLUSIONS}

Site 370 is located at the base of a relatively poorly developed continental rise, in the deep-water basin off Cape Santin, Morocco.

The thick sedimentary section visible on the seismic profiles (Figures 2 and 4) was sampled down to a total penetration of 1176.5 meters. The upper part, down to about 420 meters was very sparsely cored and, from that level down to the total depth, coring was regularly spaced by alternating coring and drilling every 9.5 meters. A total of 51 cores were recovered representing 202.7 meters out of the 483 meters attempted $(41.2 \%)$.

The operations were plagued by a succession of minor incidents, such as a one-day delay due to bad weather, occasional plugging of the bit that had to be freed twice with the use of a center bit, malfunction of the flapper valve, weakening beacon signal, extremely low rates of penetration in sticky clays and cemented siltstone and sandstones. Nevertheless, the drill bit performed well during a record time of $121.59 \mathrm{hr}$ of actual rotation on the bottom of the hole. The hole had to be abandoned only because of time constraints at the end of this cruise, after having reached sediments of lower Cretaceous age.

The section as a whole is monotonous and consists predominantly of marls and clays with abundant coarser terrigenous detritus almost constantly present throughout (Figure 10). The nature of the sediments was somewhat unexpected and reflects an evolution different from the basin located south of the Canary Islands-Atlas zone.

\section{MOST SIGNIFICANT RESULTS}

\section{Terrigenous Character of the Sediments}

The sediments display regular successions of turbidite sequences occasionally separated by pelagic intervals. Other redeposition features probably of more proximal character, are flow and current structures, and slumps (up to $80 \mathrm{~cm}$ thick) particularly in the Lower Cretaceous layers. Associated with the slump structures and the current structures are convoluted silt and sand beds, "floating" pebbles in fine-grained slumped sediments, and current ripples. All these structures suggest deposition on a deep-sea fan and are typical of lower continental rise environments.

The composition of the terrigenous components does not seem constant throughout the section. During the Cretaceous and during the Neogene, siltstones and sandstones are mainly composed of quartz, possibly reflecting very active erosion on land. During the 


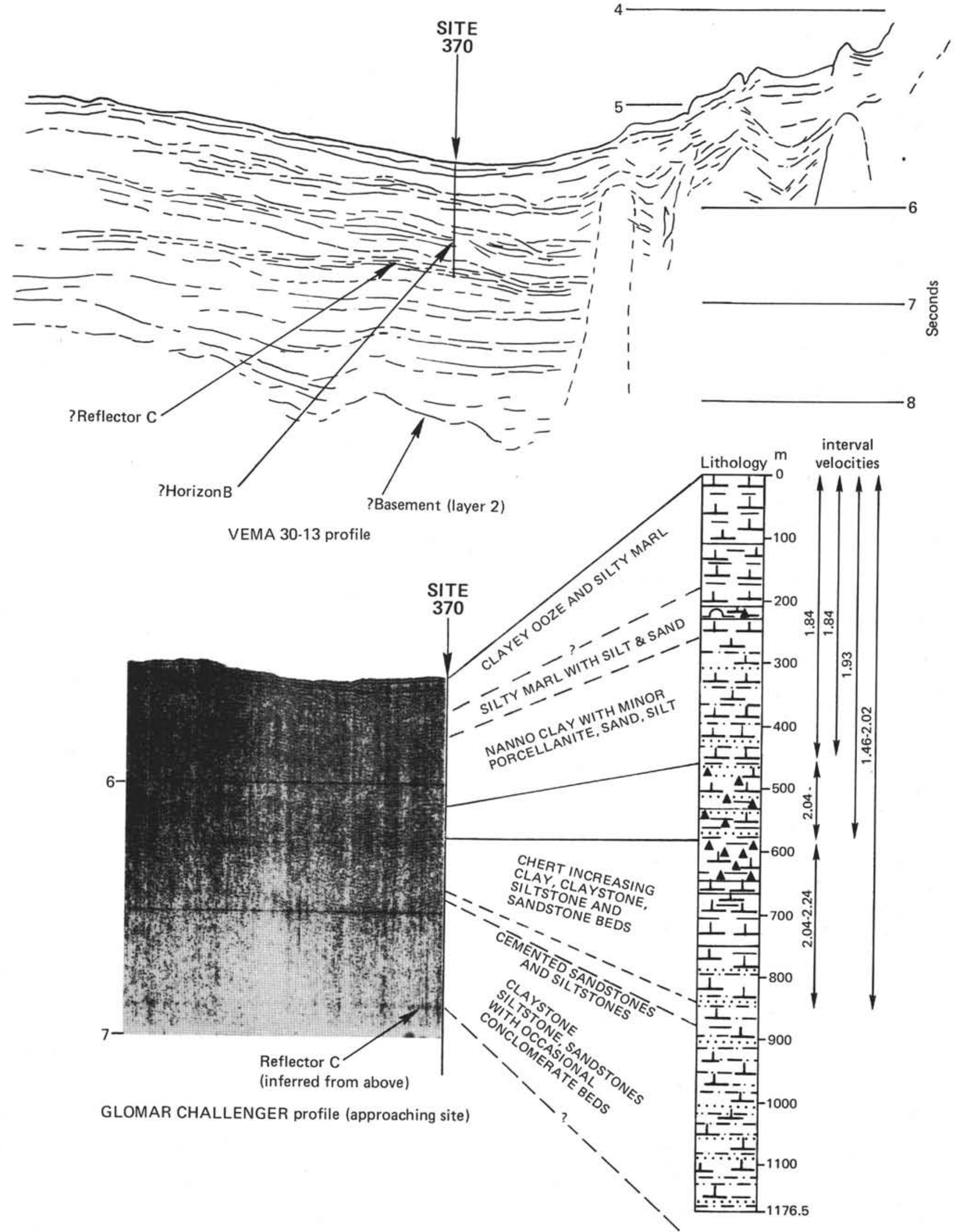

Figure 9. Correlation of seismic-reflection profile with drilling results at Site 370. Top profile is from Vema 30 and lower one is Glomar Challenger 41. 


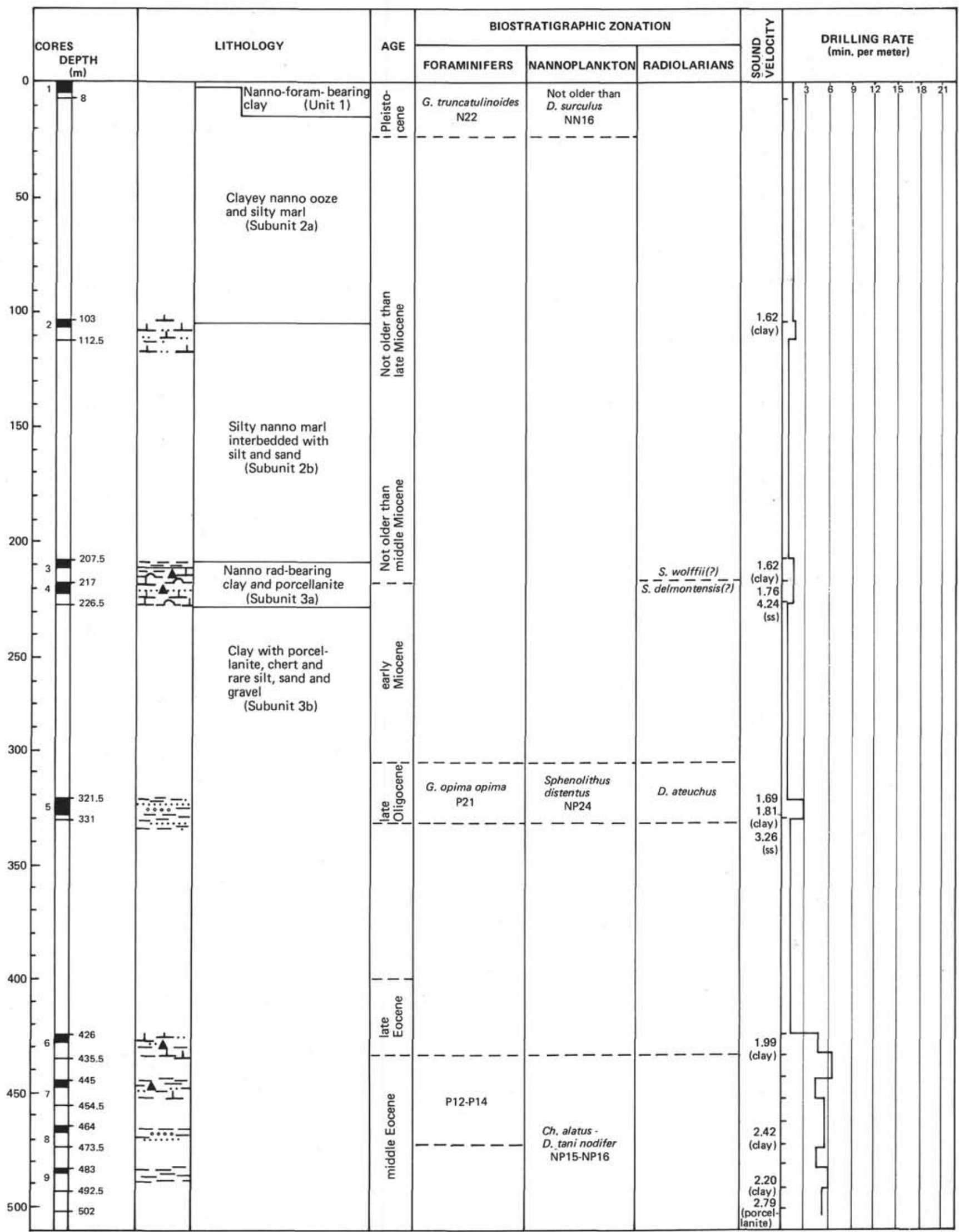

Figure 10. Graphic summary of lithology, age, biostratigraphy, sonic velocity, and drilling rates for Site 370. 


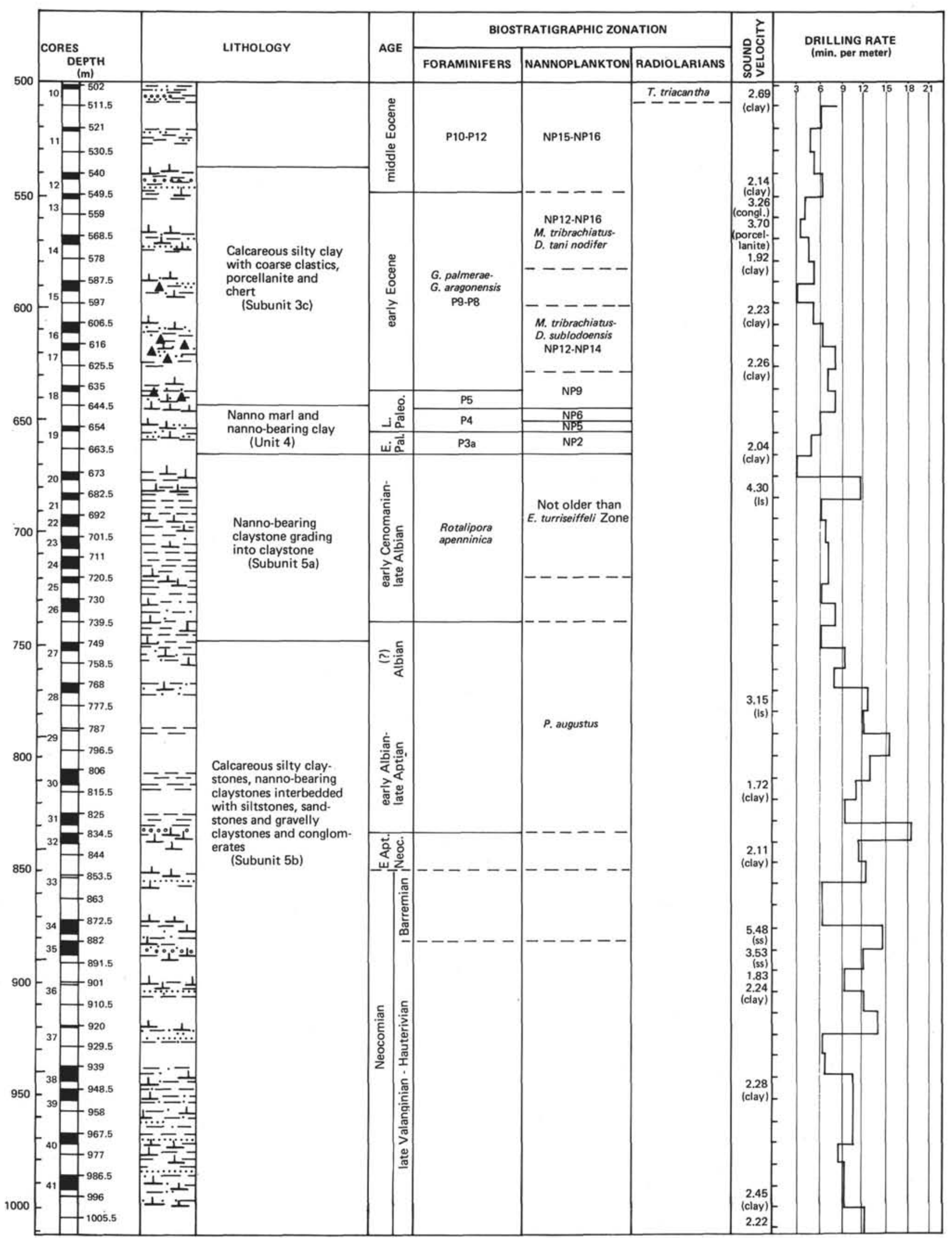

Figure 10. (Continued) 


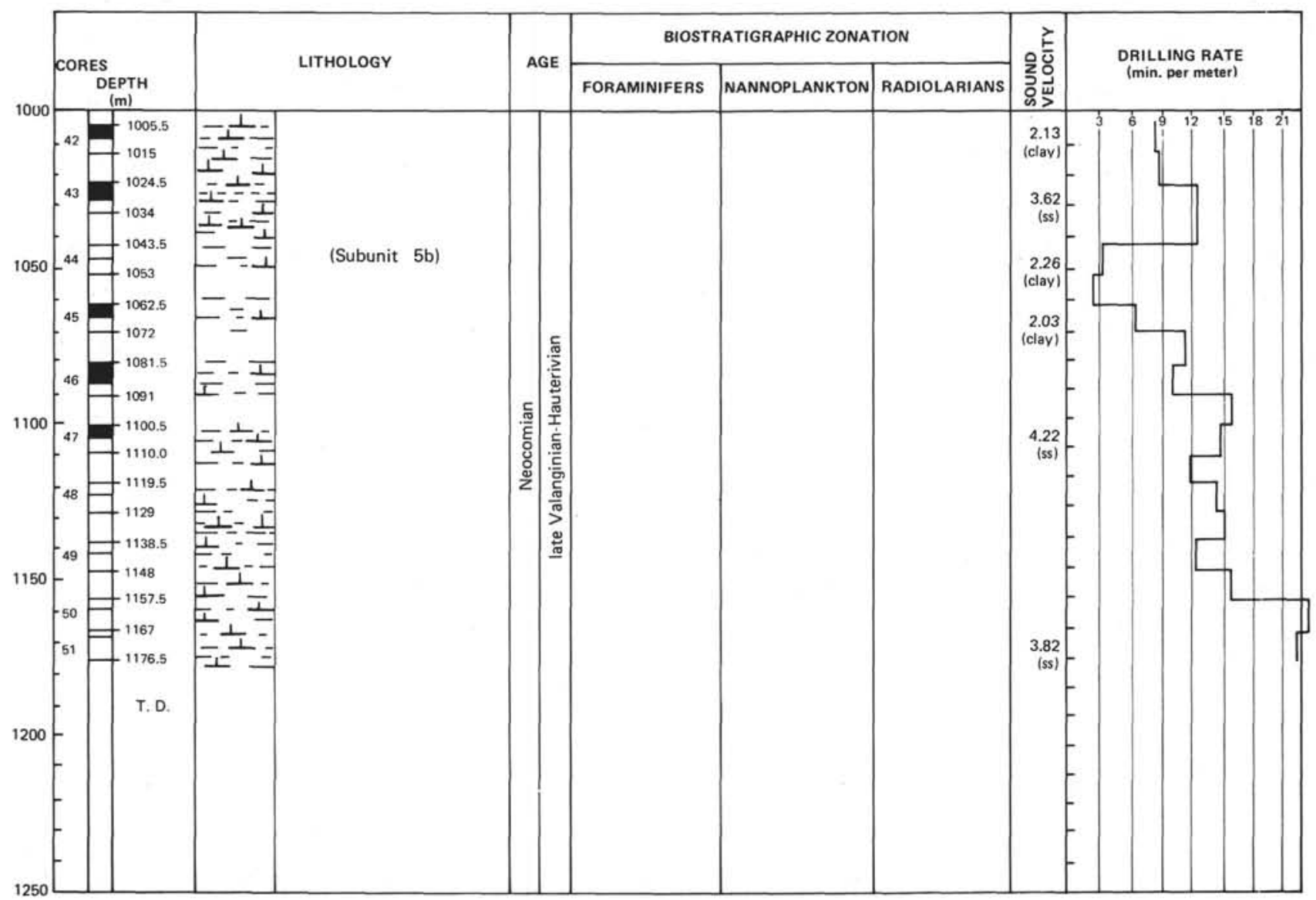

Figure 10. (Continued).

Eocene the composition of the coarse-grained sandstones and conglomerates is different and consists mainly of redeposited clay and mud pebbles, porcellanite fragments, detrital biogenic material and very abundant glauconite. The origin of this material is not clear. It might have come from the nearby continental rise, slope, or shelf, and redeposition could have been triggered by the orogenic phase responsible for the building of the Atlas Mountain in the Eocene. However, it might also be related to the Eocene uplift of seamounts northwest and west of Site 370 associated with active tectonics in the Azores-Gibraltar zone (see Site 135, Leg 14, Hayes, Pimm, et al., 1972).

The sedimentary section at this site, especially the lower part, is different from that sampled in the Cape Verde Basin at Site 367. The most striking difference is the permanence at Site 370 of coarse terrigenous deposits. At Site 367 these sediments were only represented by silty clays in the Late Cretaceous and Tertiary and coarse terrigenous material was essentially restricted to the Pliocene and Pleistocene. This main difference might be explained by the proximity of the Atlas zone, and its tectonic history; the absence or small size of coastal basins in western Morocco; or different climatic environments. It seems that the combination of tectonics and erosion in the Atlas zone could have played a major role in the supply of terrigenous material. Because Site 370 lies close to the westernmost end of the west-southwest-east-northeast trending Atlas parallel mountain ranges and troughs, we might invoke lateral transportation of the coarsegrained terrigenous material parallel to this trend as is observed for the flysh basins in the Alps and in the western north and eastern south Pyrenean chain. The terrigenous deposits of Site 370 might represent the western lateral equivalent of the Early Cretaceous deep water marls and marly limestones of the Tell and Atlas "geosyncline" facies.

A hiatus of 35 m.y. is observed between the late Cenomanian and the middle Paleocene so that most of the Late Cretaceous is missing. The absence of facies change between the layers found above and below the hiatus suggests that erosion might be largely responsible for this gap. If we assume that during the time corresponding to the hiatus the rates of accumulation were the same as the ones observed above and below, a total of approximately 200-400 meters of sediments might have been removed. No physical property changes, hence no seismic reflector was found to account for the hiatus, possibly because sediment overburden erased these effects through compaction and diagenetic lithification of the sediments. It is interesting to note that a very comparable hiatus was observed in the North American Basin (Site 105, Hollister, Ewing, et al., 1972) where it is attributed to erosion by bottom currents. Naturally, if erosion was the main factor, it might have been aggravated by low sediment input in the basin during the Late Cretaceous. 
Because of the great water depth and to a probable high level of the CCD (suggested, at least in the North American Basin, by absence of carbonate in the sediments resting directly on oceanic crust of EarlyLate Cretaceous age at Site 9, Leg 2), the biogenous input should have been greatly reduced. The terrigenous input might also have been reduced as suggested by the occurrence of Late Cretaceous pelagic calcareous shales devoid of coarse terrigenous detritus in the Tellian Trough.

As at previous sites, an increase in the carbonate content of the sediment occurs around the middle Miocene. It is not very well documented at this site, however, because the upper part of the hole was only poorly sampled.

The early Cretaceous sediments are also different from those sampled in the Cape Verde Basin and Rise areas as well as in the North American Basin. The black shales are absent in the basins off Morocco. The clays and silty clays, however, are dark colored in the Aptian-Cenomanian interval and the organic carbon content reaches $5 \%$ in some samples. This difference might only reflect the larger terrigenous input observed at this site. It is also possible that bottom circulation and/or supply of organic material were different in the Moroccan area. This would imply some basin differentiation possibly caused by the presence of physiographical barriers between the northern and southern basins. More detailed studies of these sediments will be required in order to establish if the darker layers at this site represent merely a diluted counterpart of the black shales or if different environmental conditions did exist in that northern area during the Early Cretaceous.

\section{Diagenesis}

Diagenesis in the sediments shows two interesting peculiarities: first the cementation of sandstone and siltstone layers by calcite, and second, the occurrence of barite rosettes, partially replaced by calcite, in Cenomanian claystones (see Dean and Schreiber, this volume). The cementation of sandstone beds by calcite is a very general phonomenon on land and is generally atributed to circulation of $\mathrm{CO}_{2}$-rich meteoric waters. Deep-sea sandstones are often poorly lithified or cemented by silica when found under moderate overburden. Here, they are cemented by wellcrystallized calcite. These well-cemented beds occur below about 850 meters subbottom. It is particularly interesting to note that, under the same overburden in carbonate sediments, sparry calcite recrystallization has been observed at other DSDP sites (see for example Site
167, Leg 17, Schlanger et al., 1973). The origin of the calcite cement is not clearly determined. It might result from partial dissolution of calcareous microfossils and preferential recrystallization in the more porous beds. The source of the calcite, however, might, as proposed for calcite cementation at Site 369, result from upward or lateral migration of solutions rich in calcium carbonate originating from nearby evaporites. The presence at this site, as at Site 369 , of barite rosettes partially replaced by calcite might also be related to similar processes.

\section{Reflectors}

The correlation between drilling results and the seismic reflection profile is relatively well established at this site (Figure 9). It indicates that one of our major objectives at this site, reflector $C$, lying at about $1.2 \mathrm{sec}$ below the bottom proved to be out of reach because of time limitations. The overlying reflectors correlate with slight changes in lithology that are well documented by physical property variations. No reflector was found to correspond with the major Cenomanian-Paleocene hiatus, and this might come from diagenetic equilibration of the physical properties above and below the hiatus because of relatively high overburden. Because no limestones were encountered in the Neocomian layers, it is possible that the top of basal carbonate layers correspond with reflector C at $1.2 \mathrm{sec}$. This would tentatively indicate an approximate Late Jurassic age for the time at which subsidence would have brought the sea floor into higher dissolution environments.

\section{REFERENCES}

Hayes, E.E., Pimm, A.C., et al., 1972. Initial Reports of the Deep Sea Drilling Project, Volume 14: Washington (U.S. Government Printing Office).

Hayes, D.E. and Rabinowitz, P.D., 1975. Mesozoic magnetic lineations and the magnetic Quiet Zone off Northwest Africa: Earth. Planet Sci. Lett., v. 28, p. 105-115.

Hollister, C.D., Ewing, J.I., et al., 1972. Initial Reports of the Deep Sea Drilling Project, Volume 11: Washington (U.S. Government Printing Office).

Renz, O., Imlay, R., Lancelot, Y., and Ryan, W.B.F., 1975. Ammonite-rich limestones from the continental slope off Morocco: Eclog. Geol. Helv., v. 68, p. 431-448.

Schlanger, S.O., Douglas, R.G., Lancelot, Y., Moore, T.C., and Roth, P.H., 1973. Fossil preservation and diagenesis of pelagic carbonates from the Magellan Rise, central North Pacific Ocean. In Winterer, E.L., Ewing, J.I., et al., Initial Reports of the Deep Sea Drilling Project, Volume 17: Washington (U.S. Government Printing Office), p. $407-427$. 


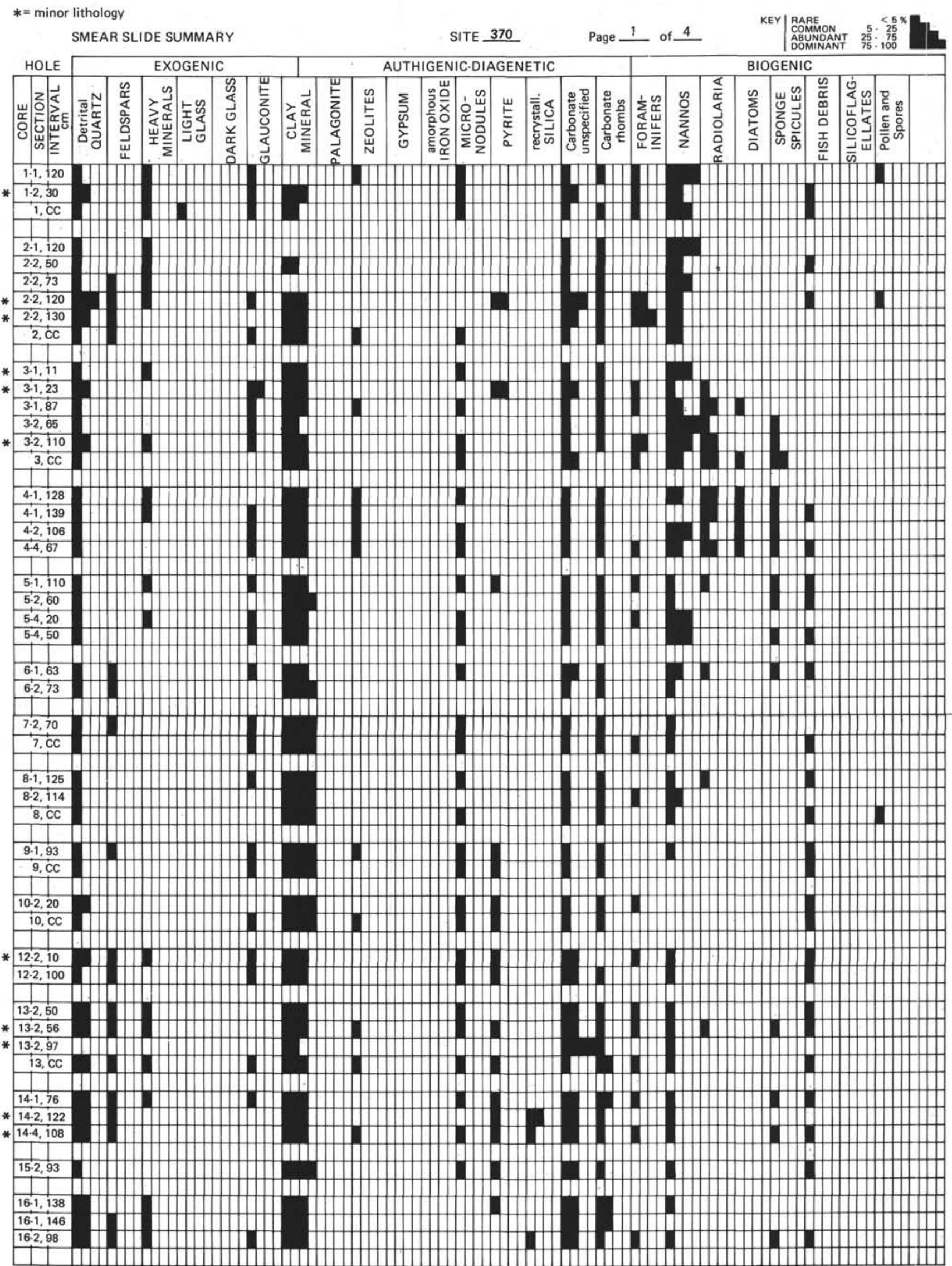


$*=$ minor lithology

SMEAR SLIDE SUMMARY

SITE $370 \quad$ Page 22 of $\underline{4}$

KEY $\mid$ RARE

COMMON 5 - 525

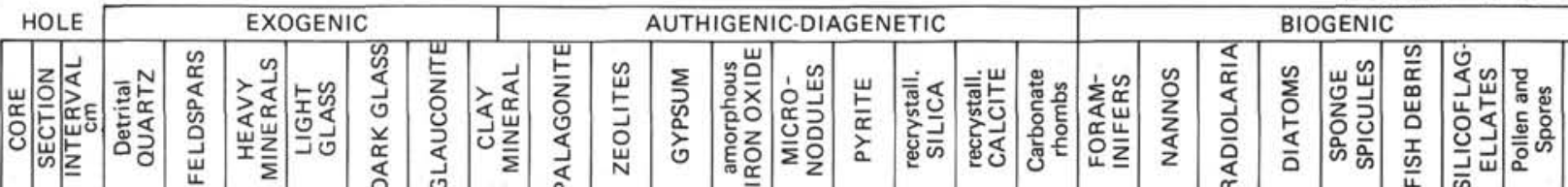

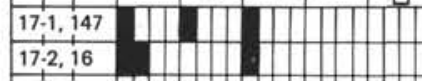

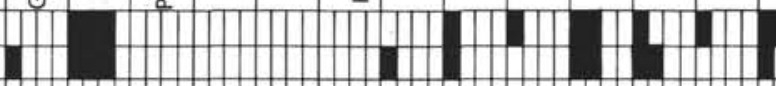

\begin{tabular}{|c|} 
\\
\hline $18-2,93$ \\
\hline $18 \cdot 2,100$ \\
\hline 18, CC \\
\hline
\end{tabular}

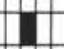

* $19-1,84$

* 19-1, 92

$19-1,132$

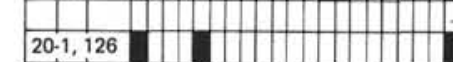
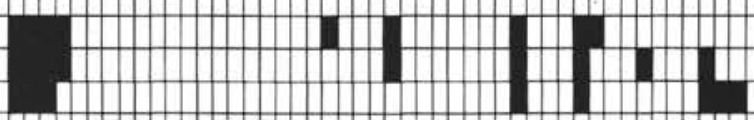

1101101

$* \frac{20,1,215}{202,2,115}$

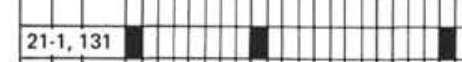

$22 \cdot 2,48$

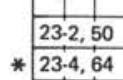

* $23,4,109$

$23-4,129$
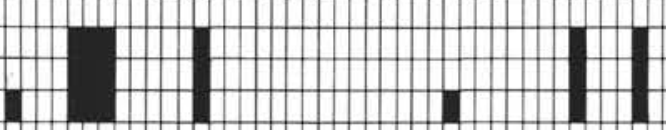

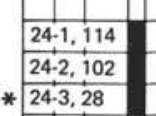

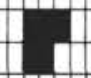

10

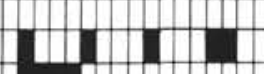

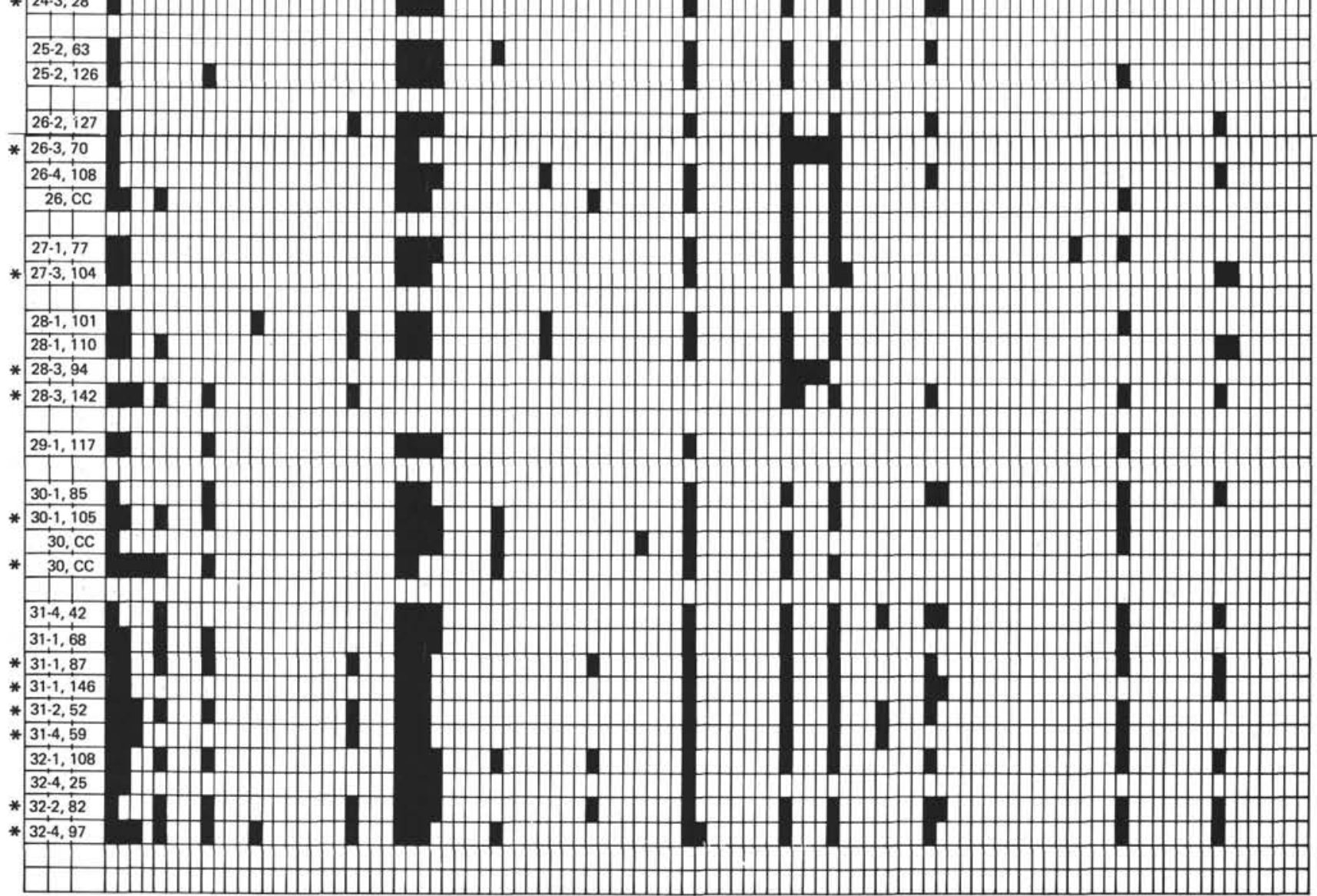


* = minor lithology

SMEAR SLIDE SUMMARY

SITE 370

Page 3 of 4

KEY RAAE

$\begin{array}{llll}\text { ABMNDANT } & 55 & 25 \% & 25 \\ \text { DOMINANT } & 75: 100 & \end{array}$

\begin{tabular}{c|c|c|c|}
\cline { 2 - 4 } HOLE & EXOGENIC & AUTHIGENIC-DIAGENETIC & BIOGENIC
\end{tabular}

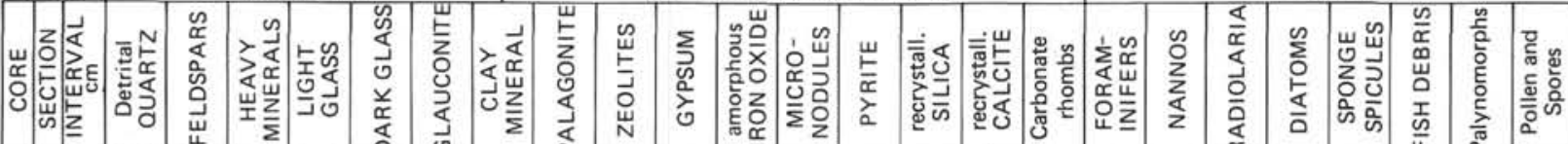

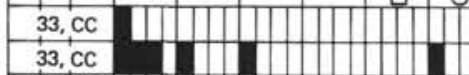

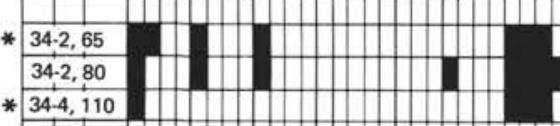

$35-2,56$

* 35-2, 105

\begin{tabular}{|l|}
$35-3,70$ \\
\hline $35-4,74$
\end{tabular}

35-5, 64

\begin{tabular}{|l|}
\hline \\
\hline
\end{tabular}

$$
\begin{array}{|l|l}
3 \\
\hline
\end{array}
$$

\section{\begin{tabular}{|l|}
\hline 37,0 \\
\hline $37, \mathrm{C}$ \\
\hline $37, \mathrm{cc}$ \\
\hline
\end{tabular}}

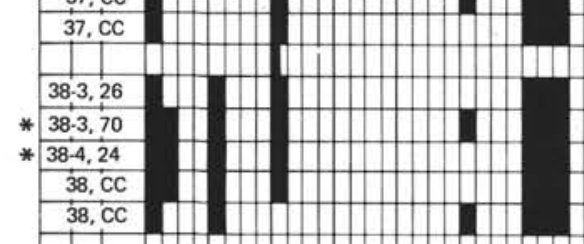

$+\mid$
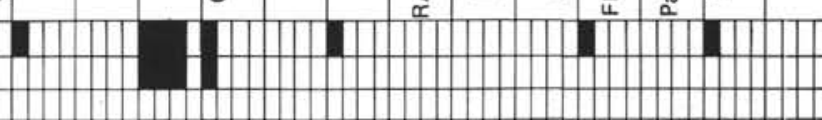

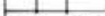

* $39-1,102$

39-2, 47

* 39-3.27
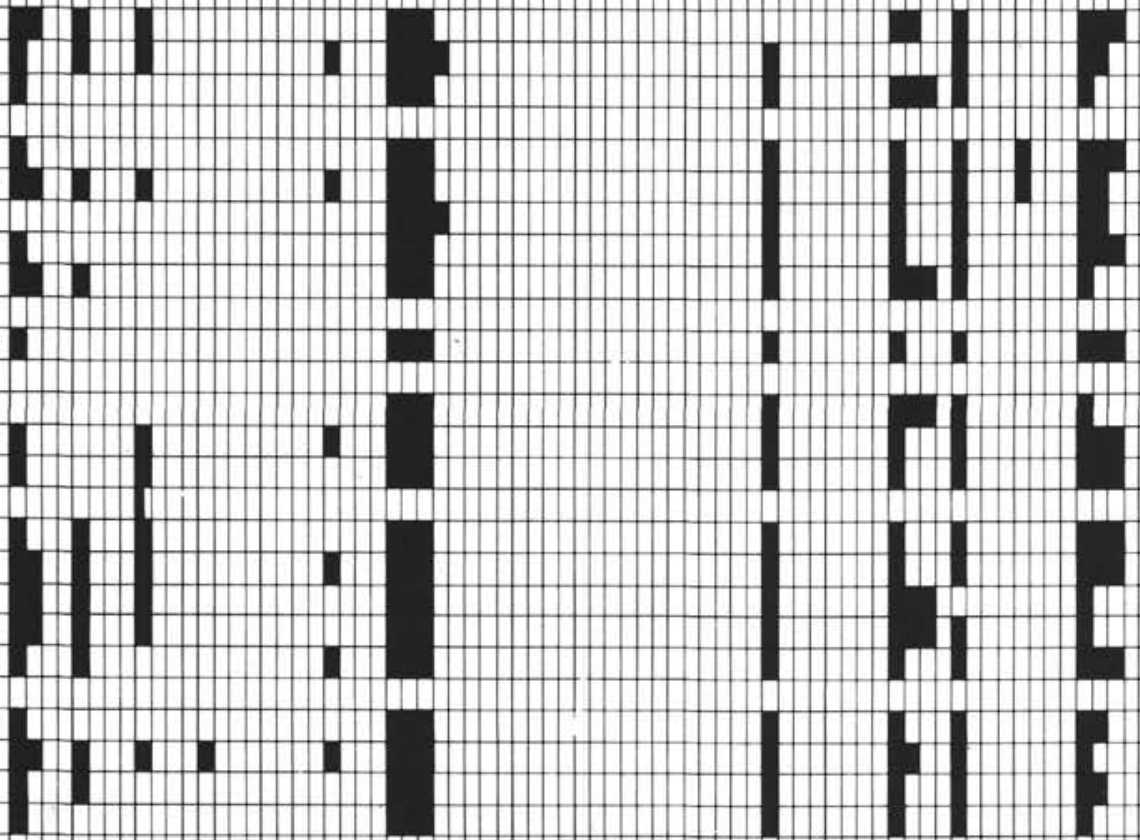

$\frac{40-2,57}{40-2,40}$
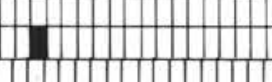

\begin{tabular}{|l|}
\hline $41 \cdot 1,3$ \\
\hline $41 \cdot 1$, \\
\hline 41,2 \\
\hline
\end{tabular}

* $\begin{array}{r}41-1,54 \\ \hline 41-2,64\end{array}$

* 41-4, 27
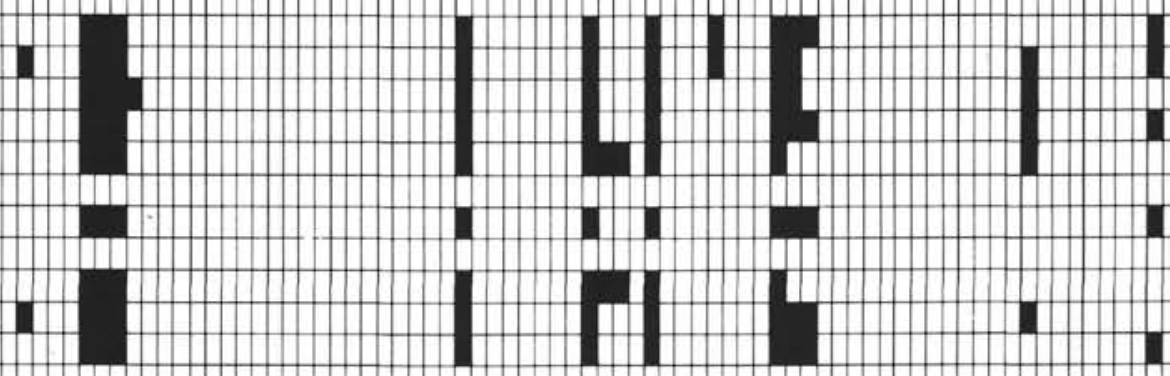

\begin{tabular}{|c|}
\hline $42-2,74$ \\
\hline $42-4,38$
\end{tabular}

* $\frac{42-4,38}{42-4,80}$

* 42-4, 93

* $\frac{1}{43-1,127}$

* 43-2, i11

* 43-3, 41
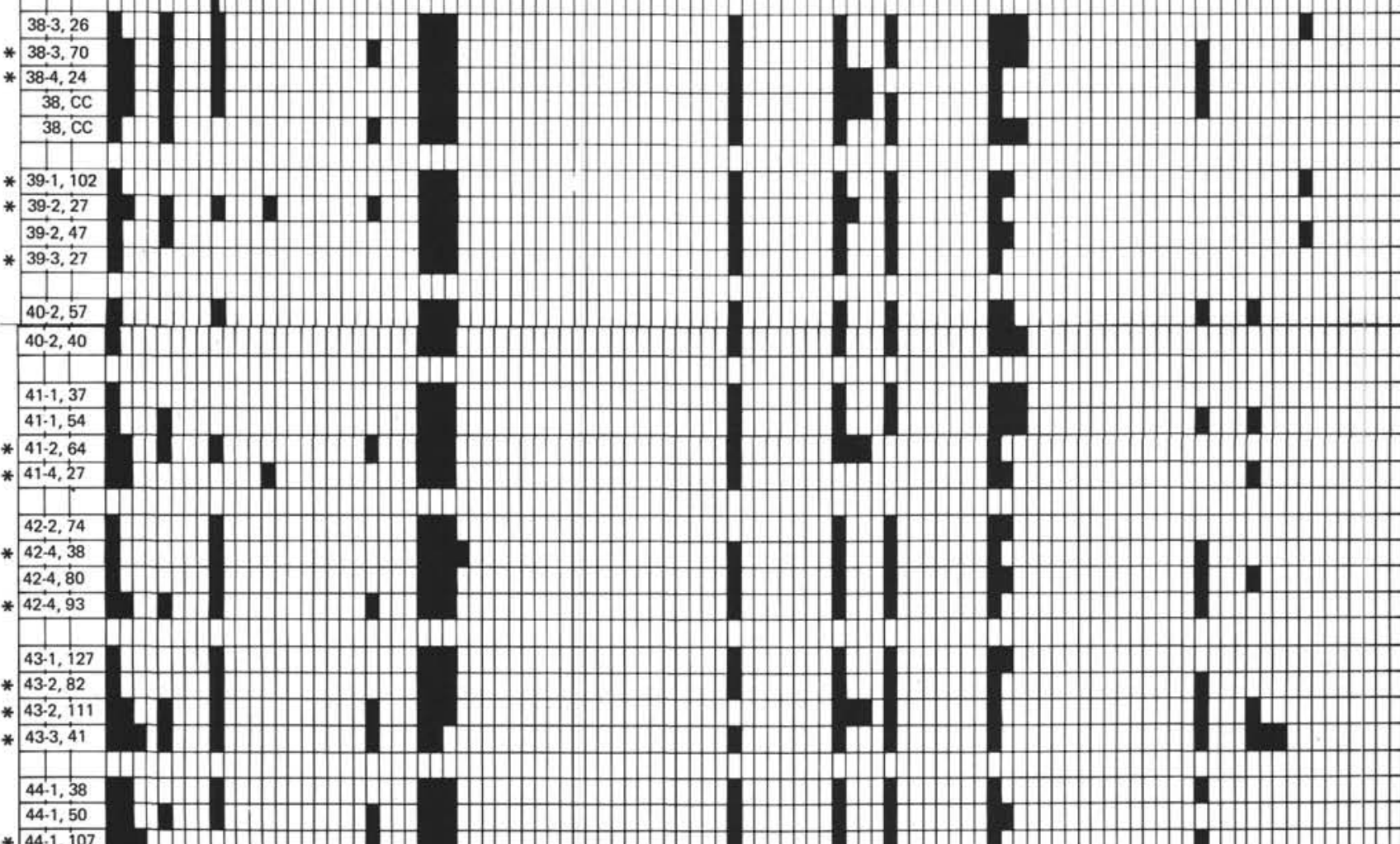

$44: 1,10$

* 44-3,31
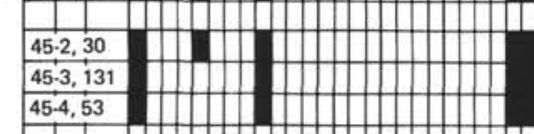

$45-4,53$

* 46-1, 135

$46-2,88$

* 46-3, 38
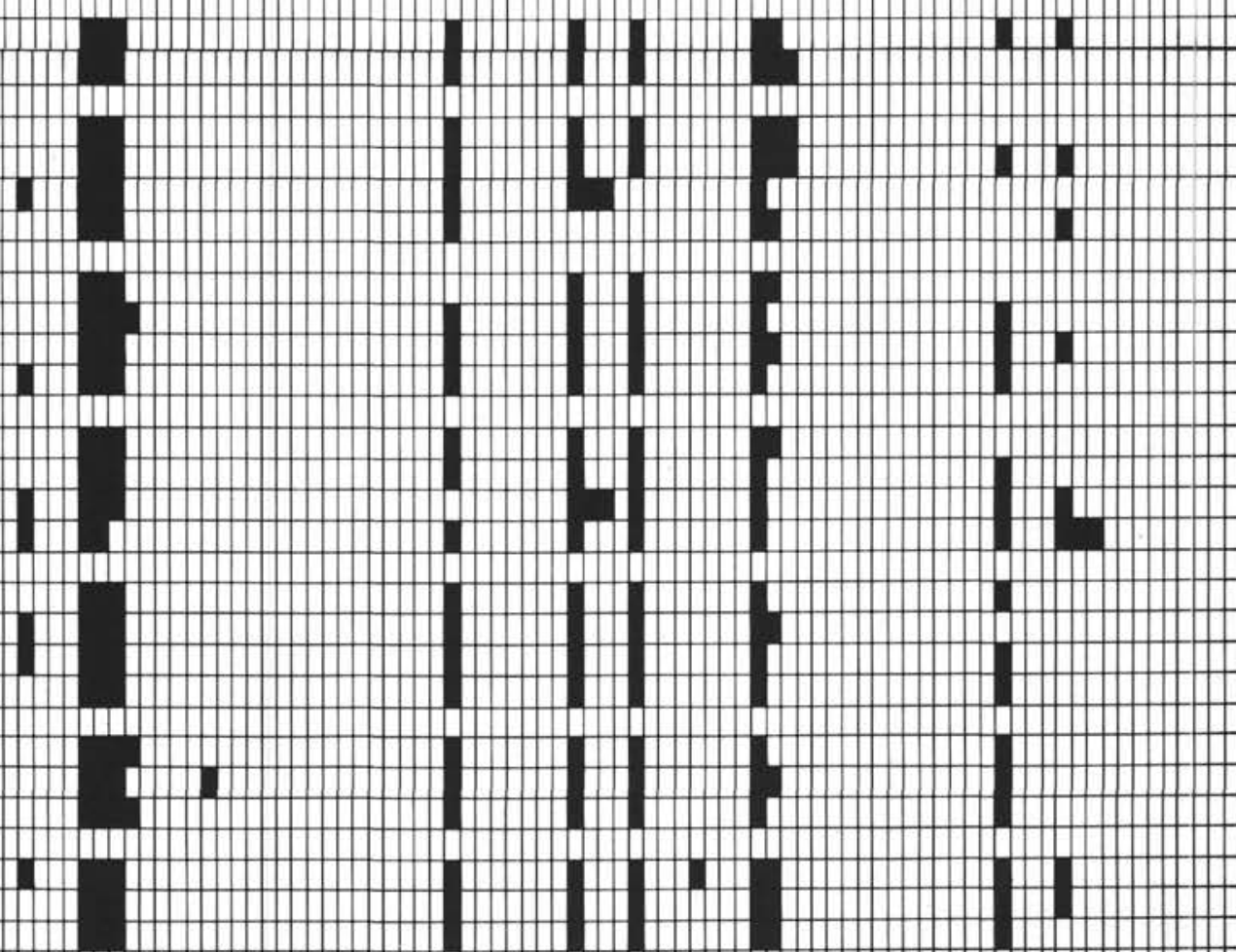


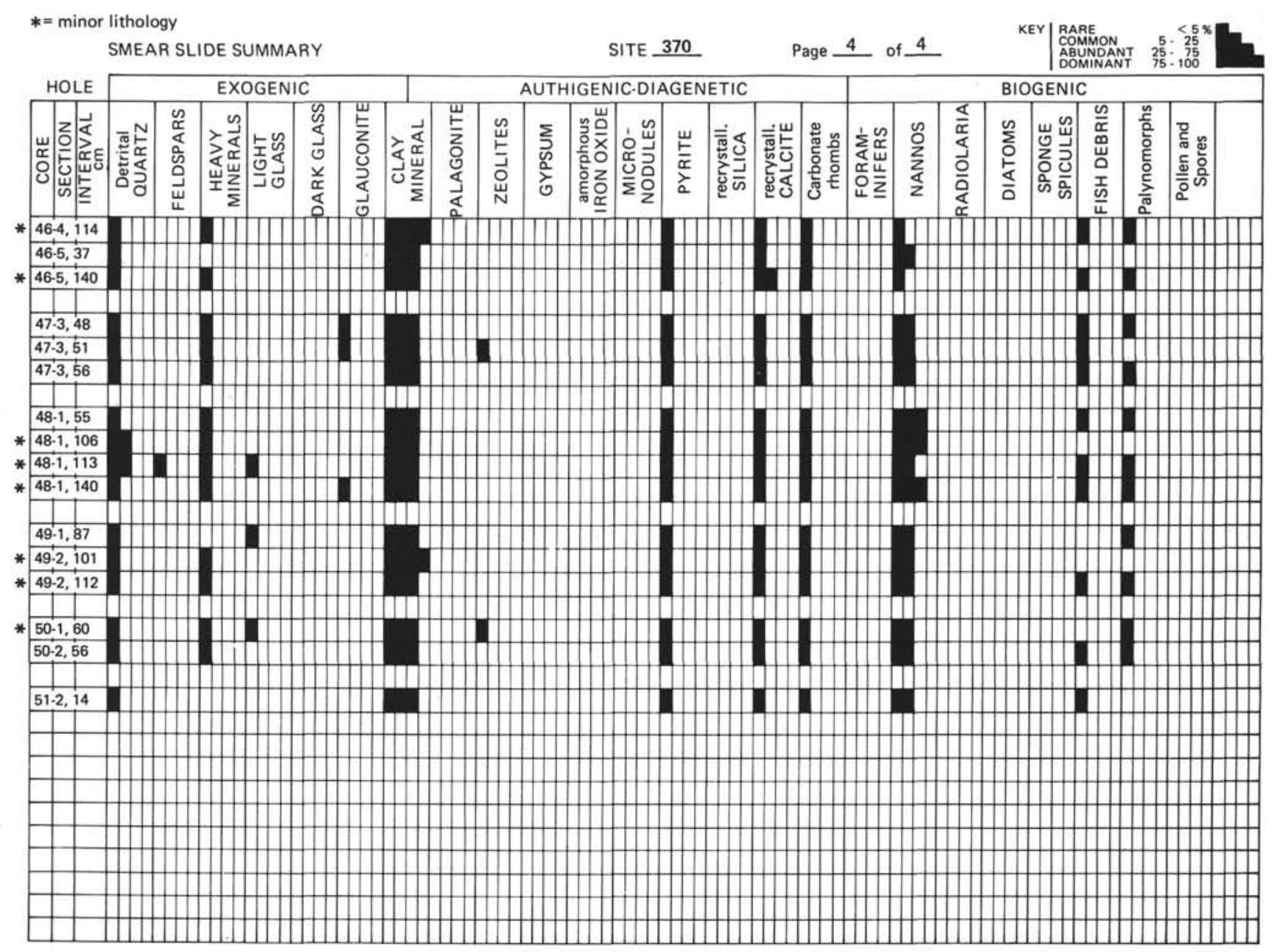




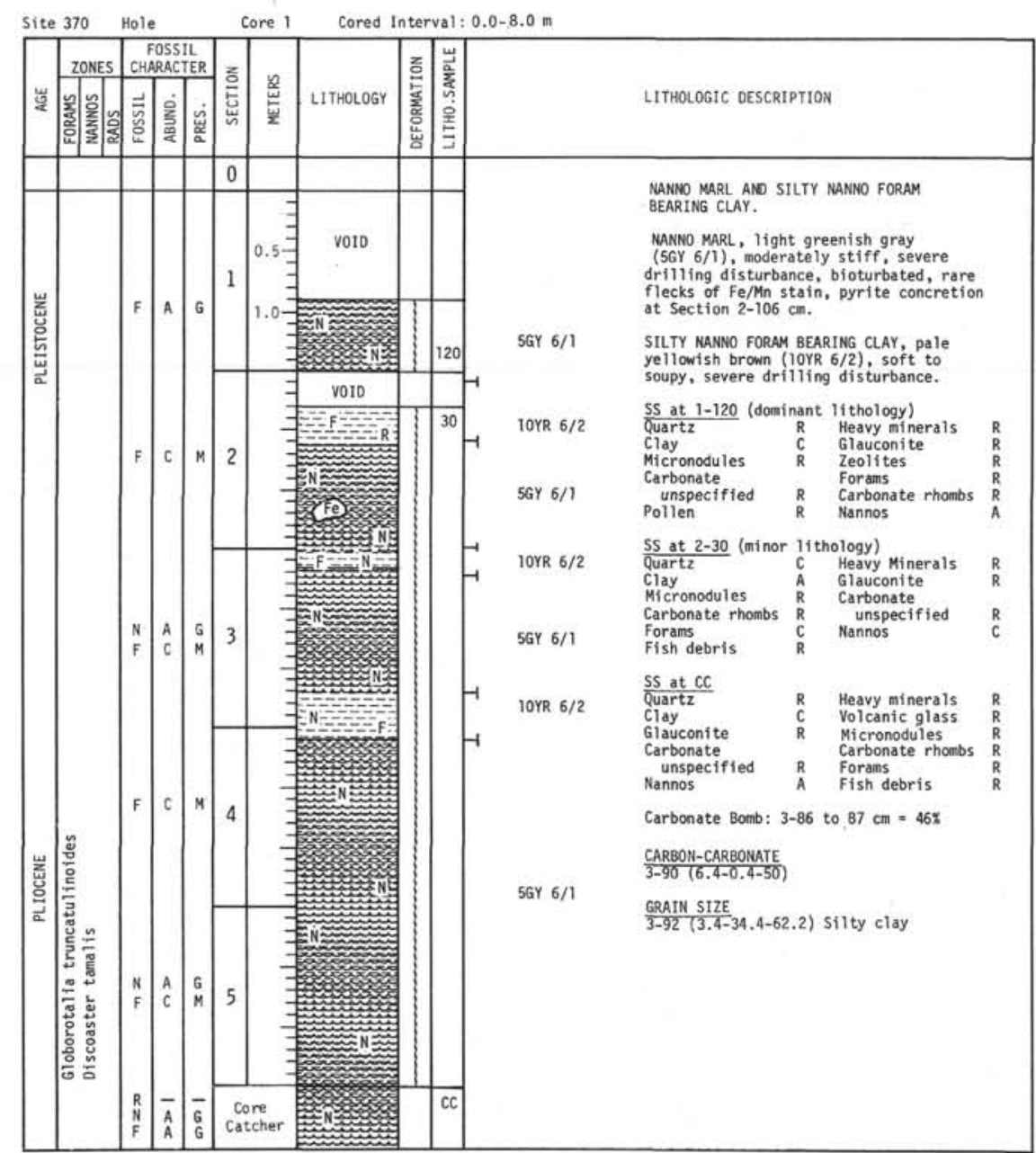

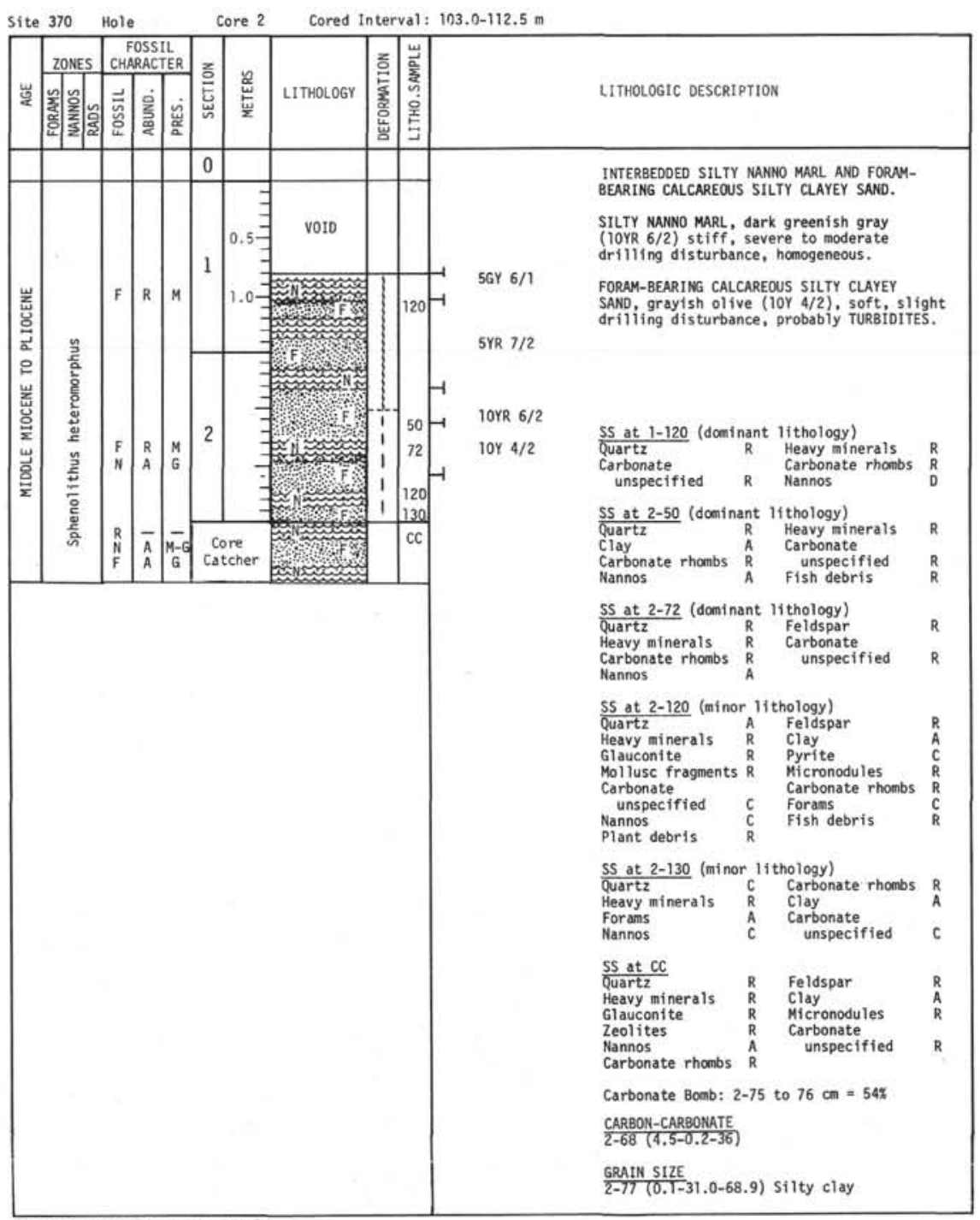




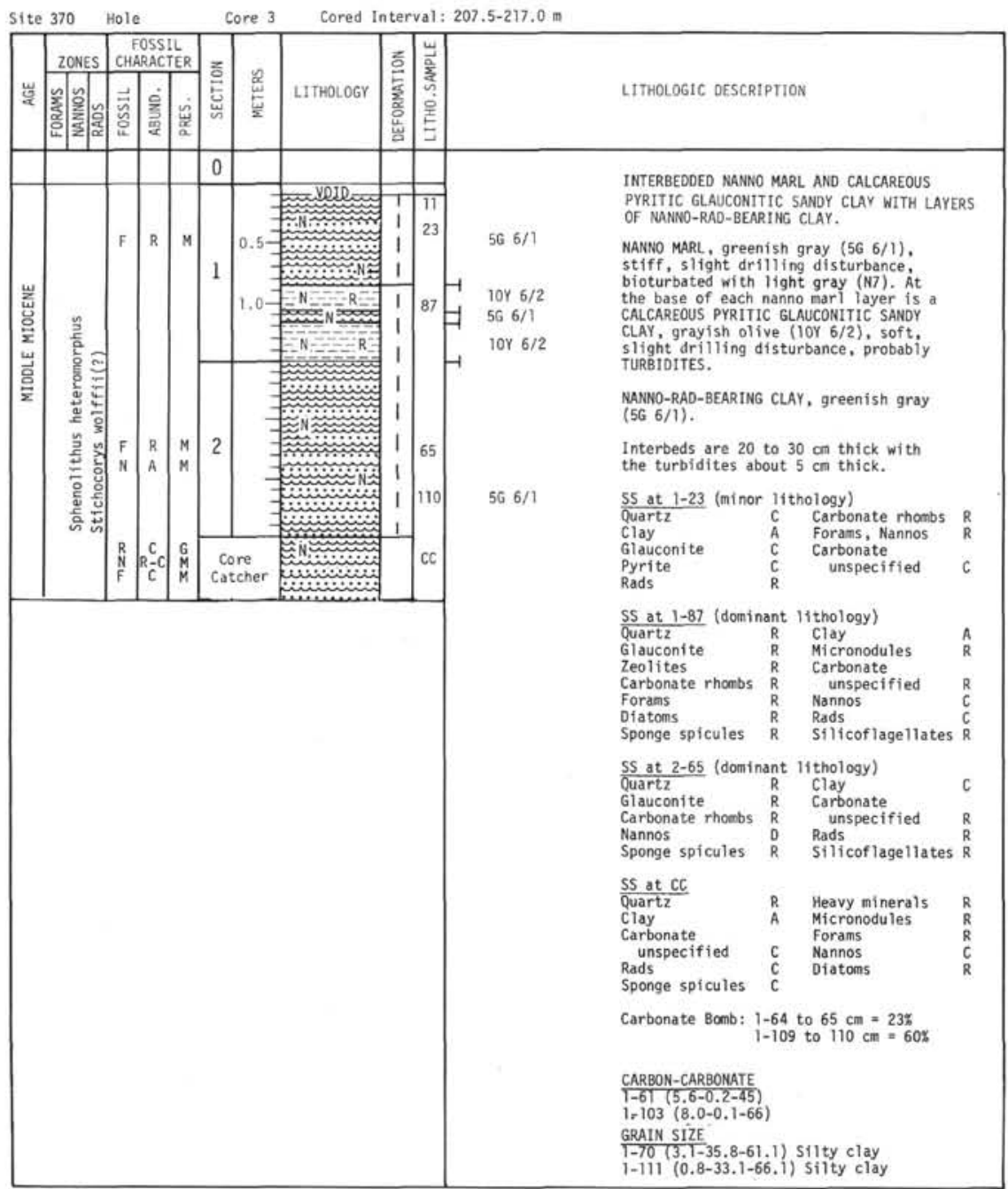

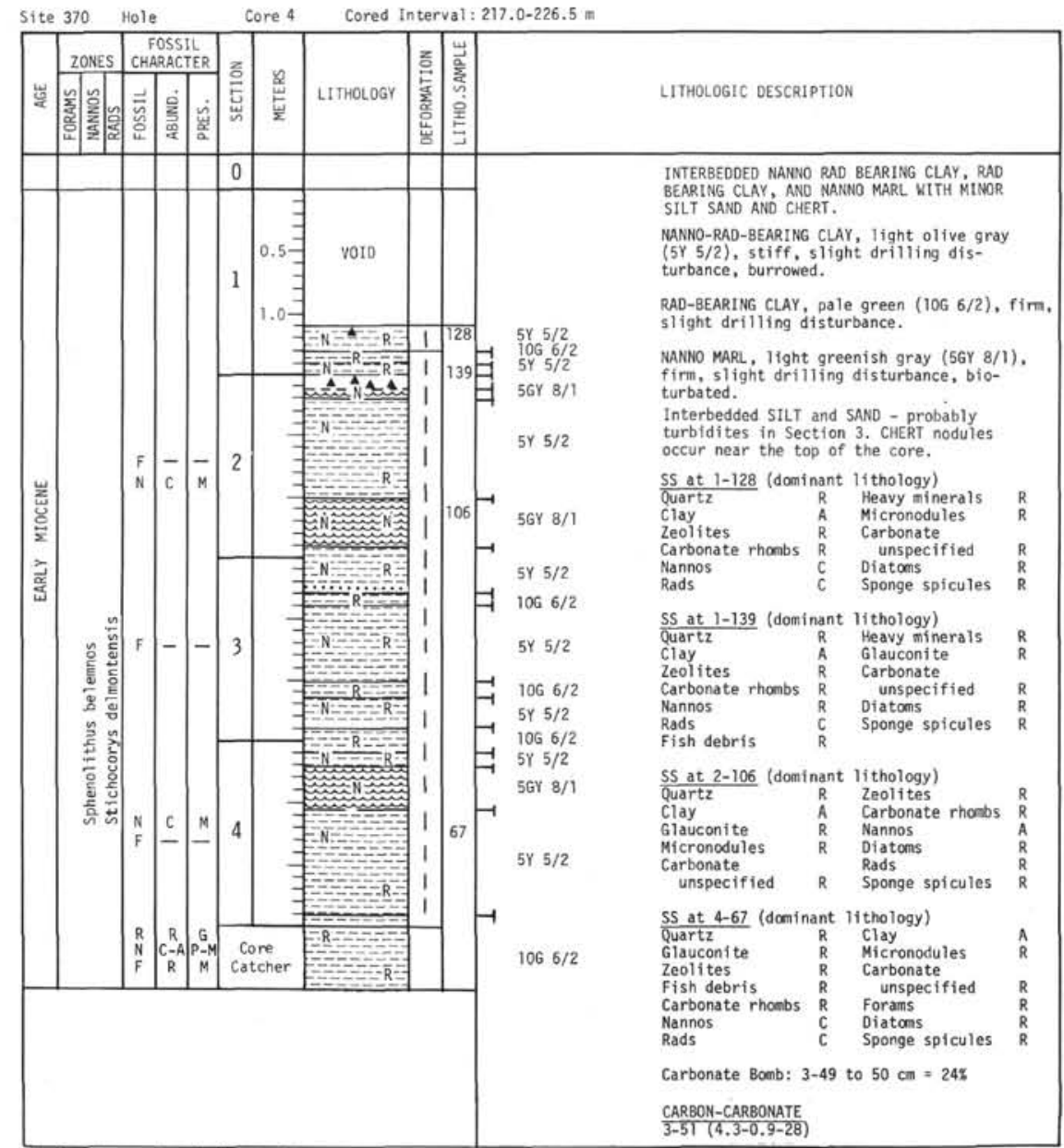

Explanatory notes in Chapter 1 


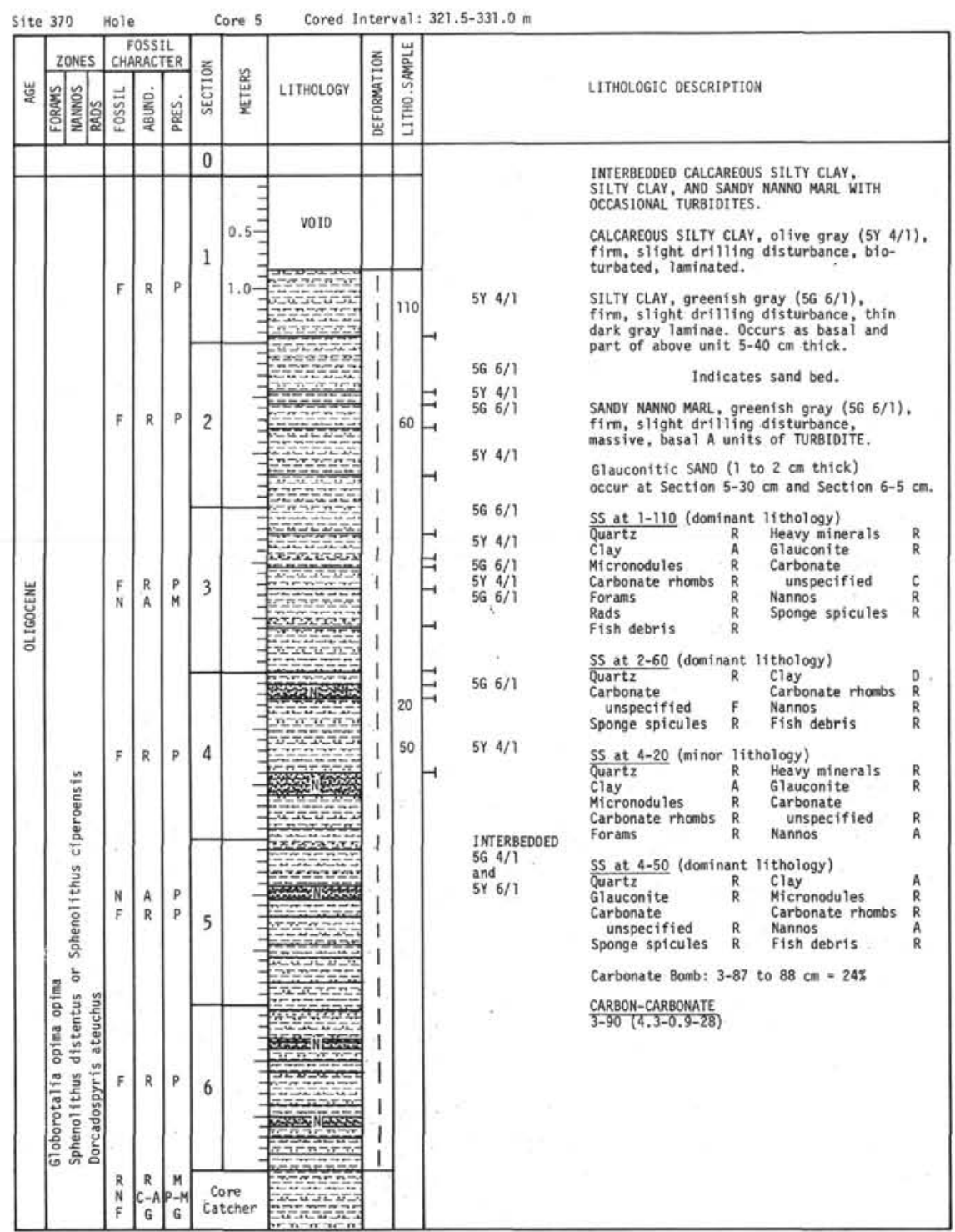

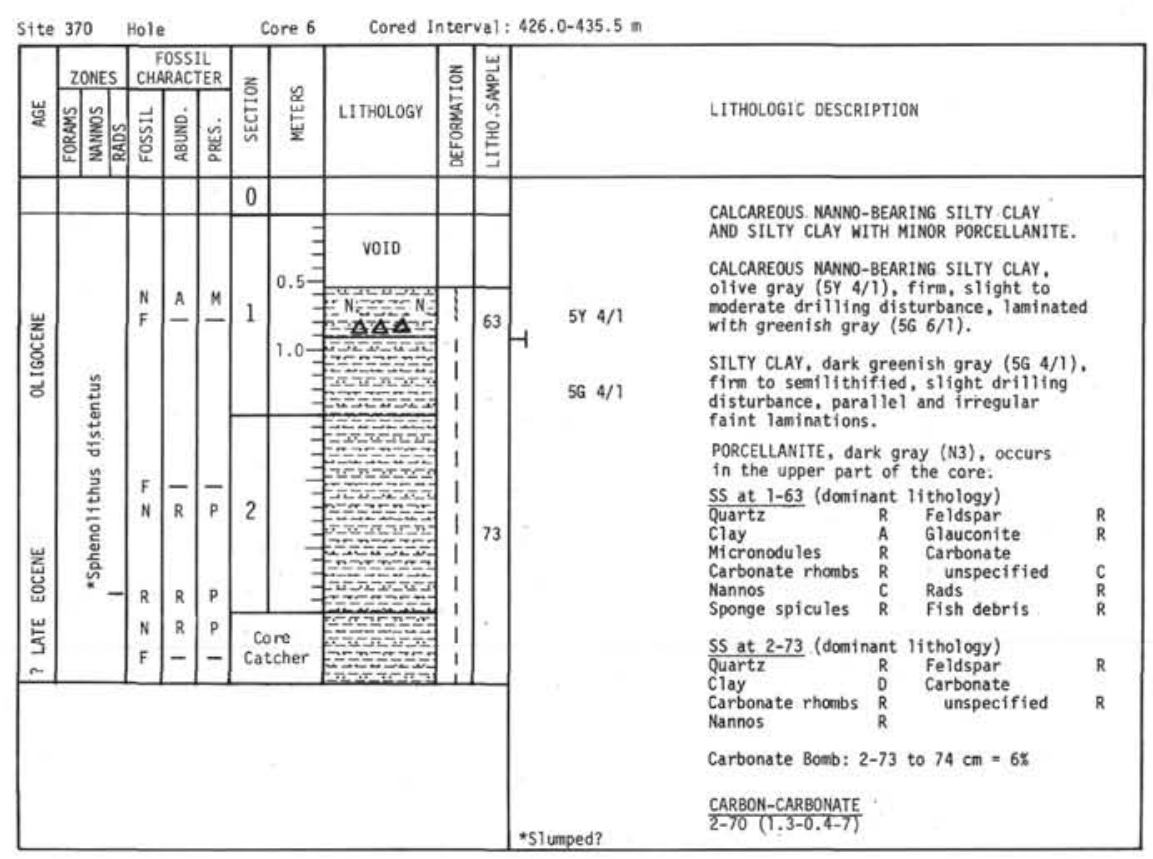

\begin{tabular}{|l|l|l|l|l|l|l|l|l|l|}
\hline Site 370 & Hole \\
\hline
\end{tabular}




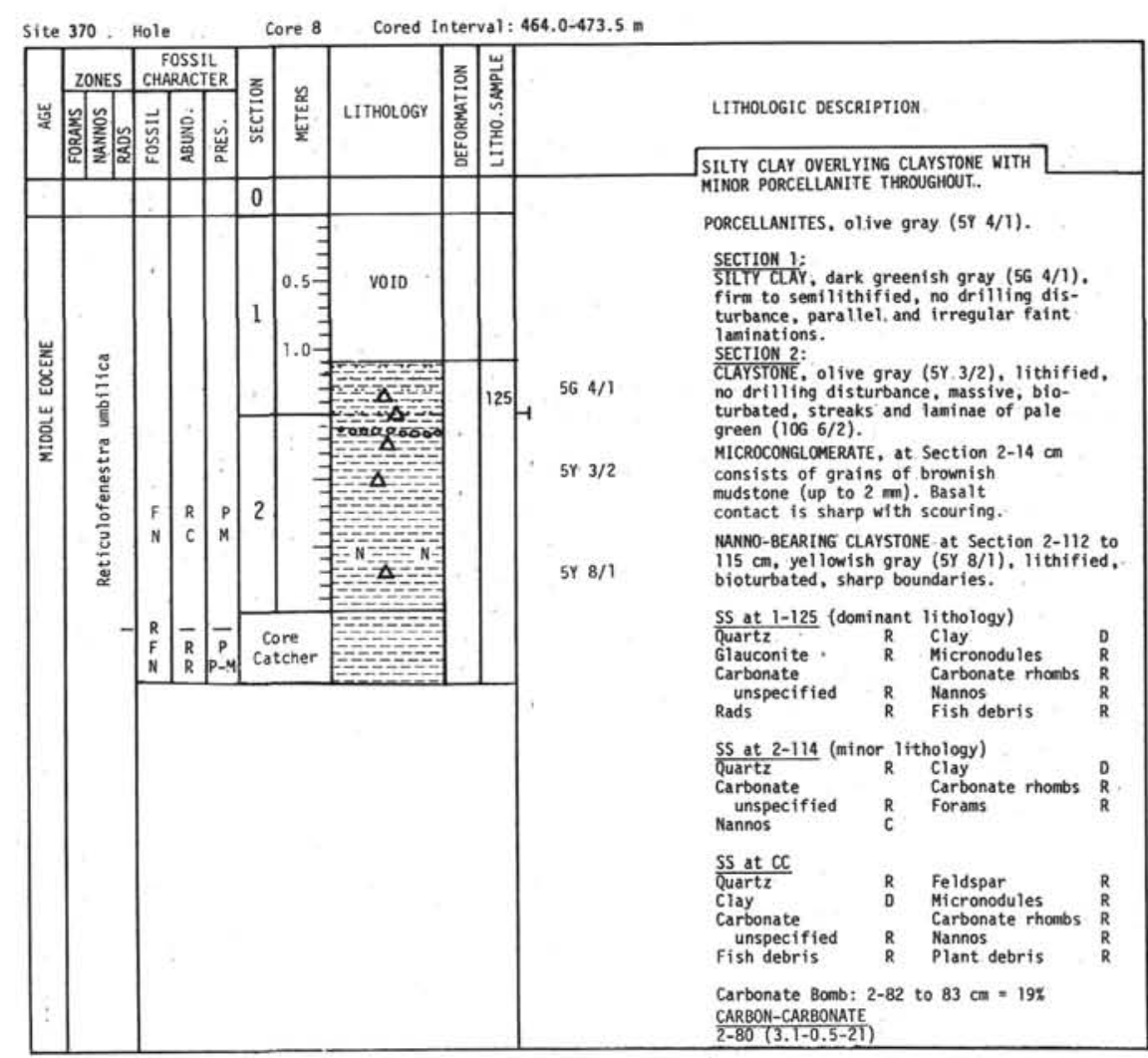

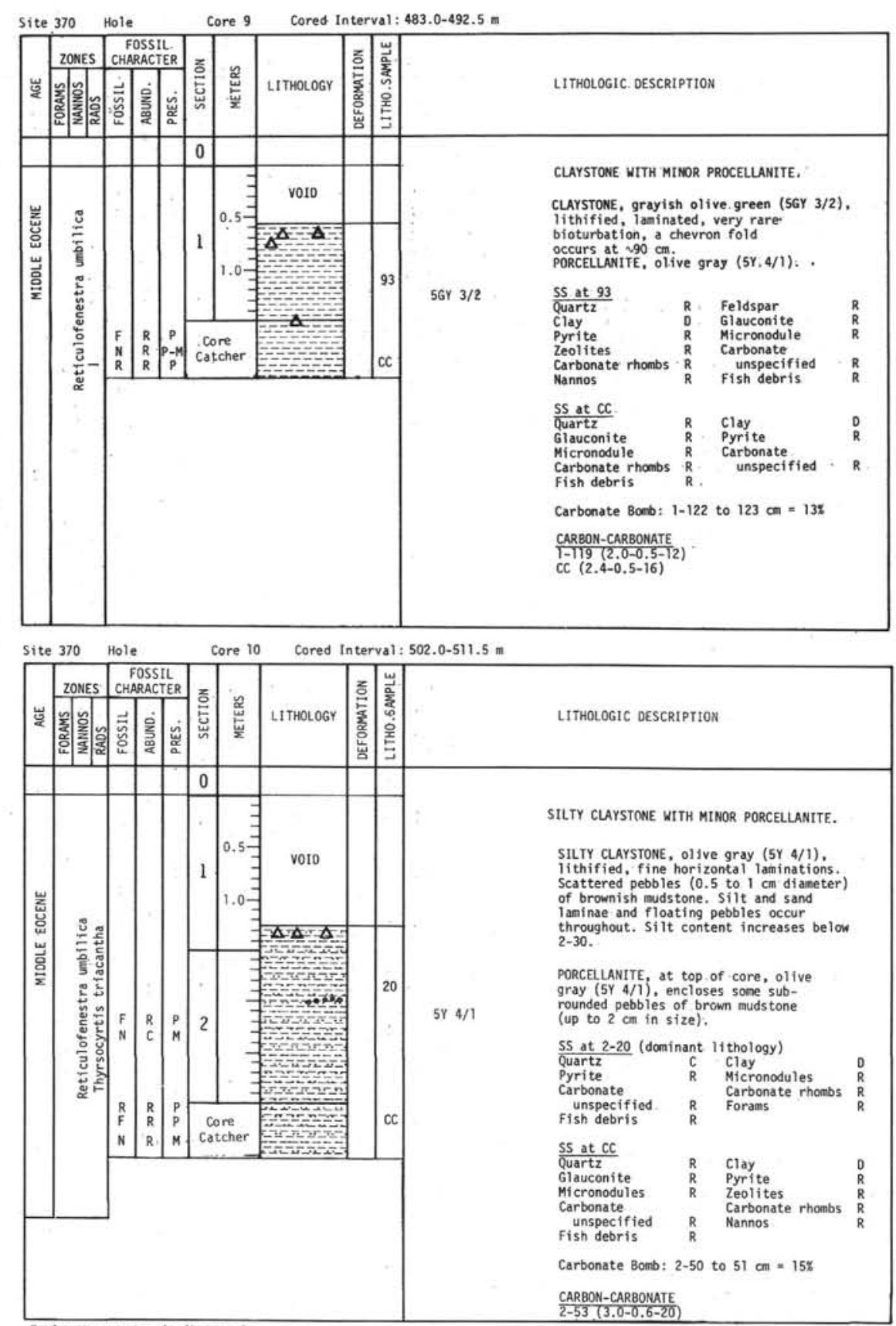



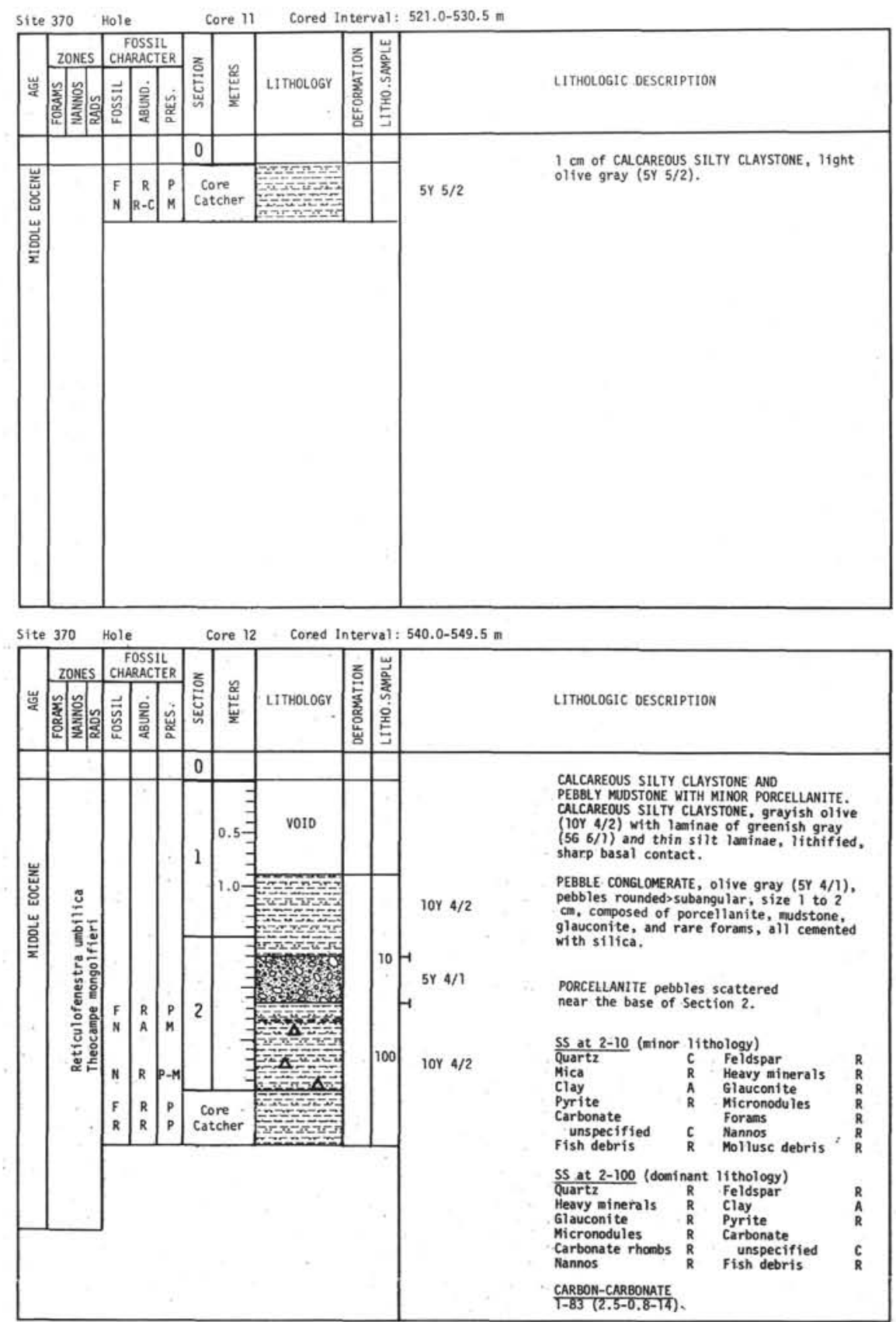

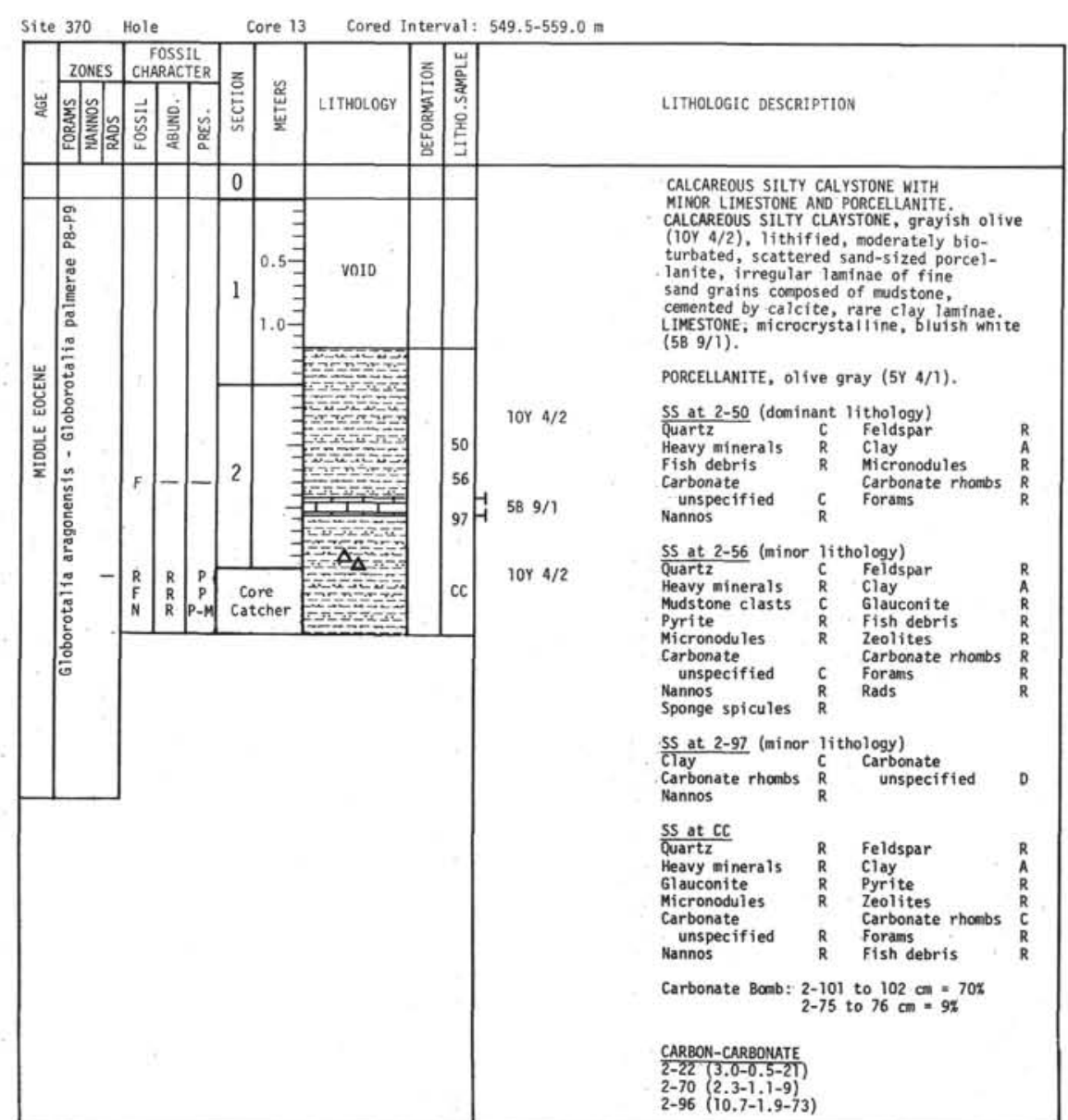

Explanatory notes in Chapter 


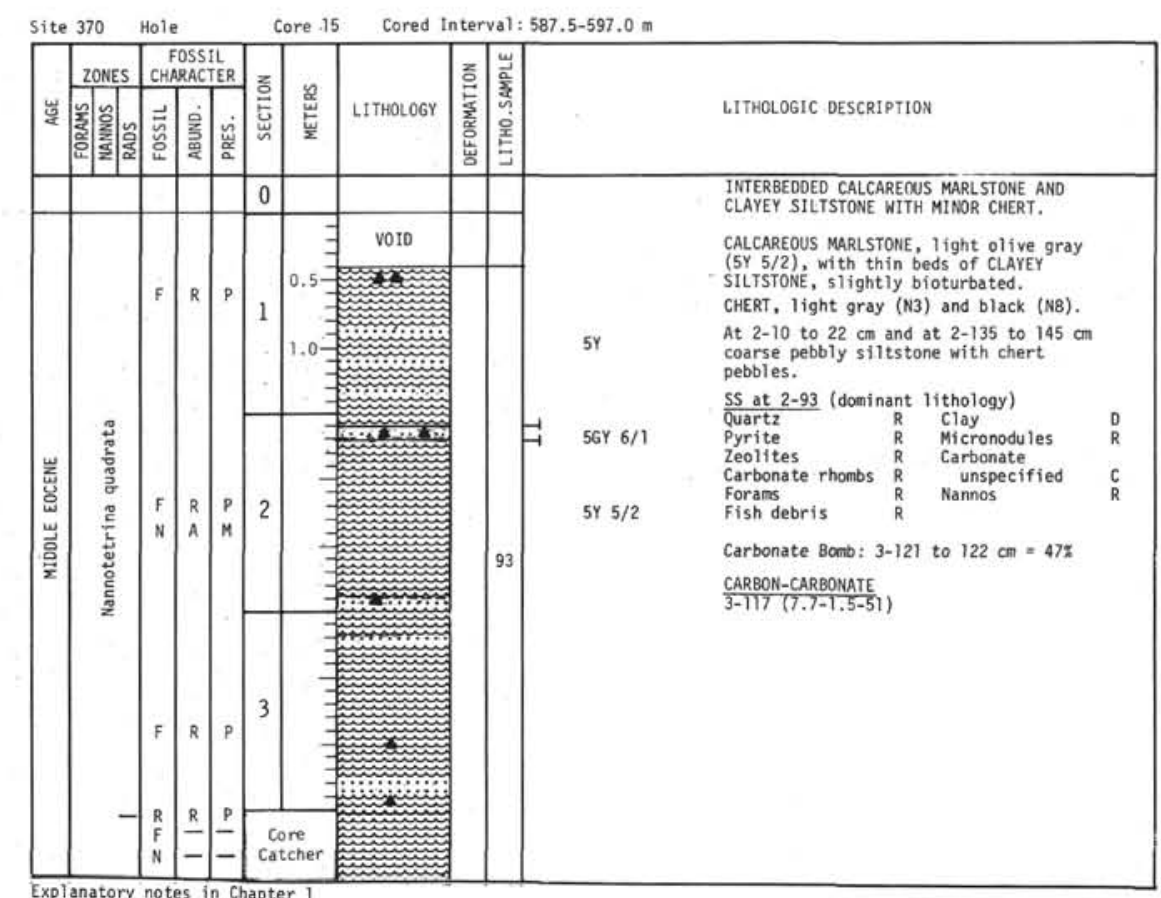




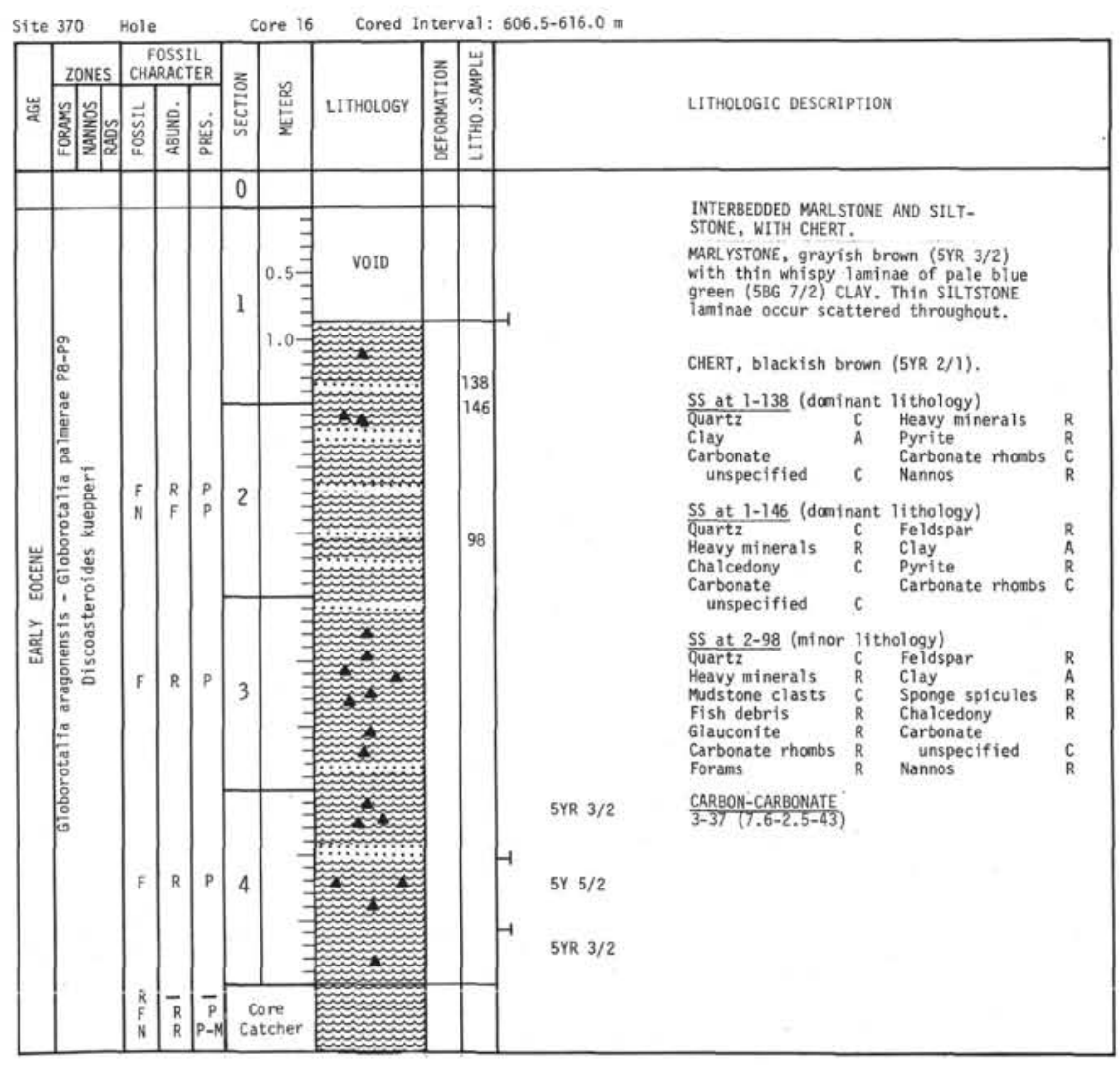

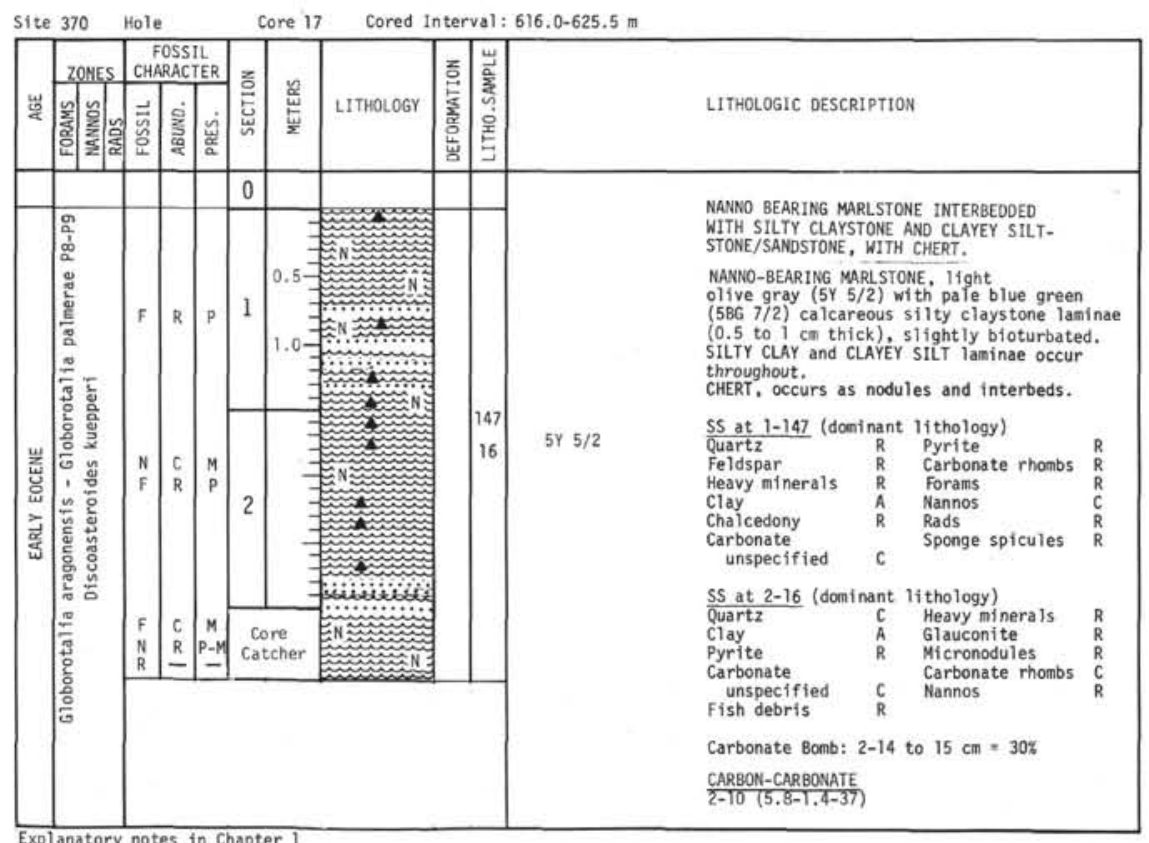




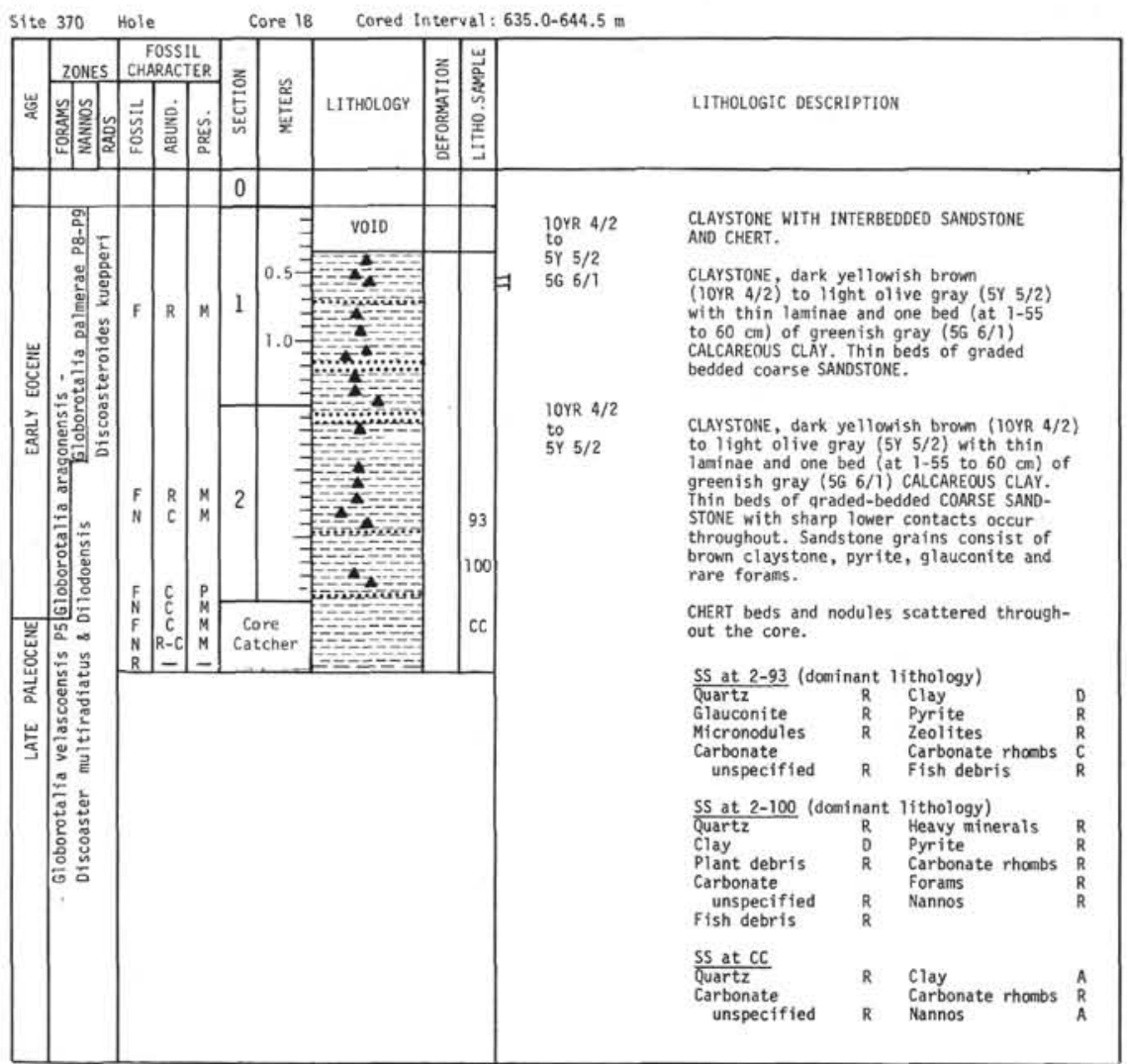

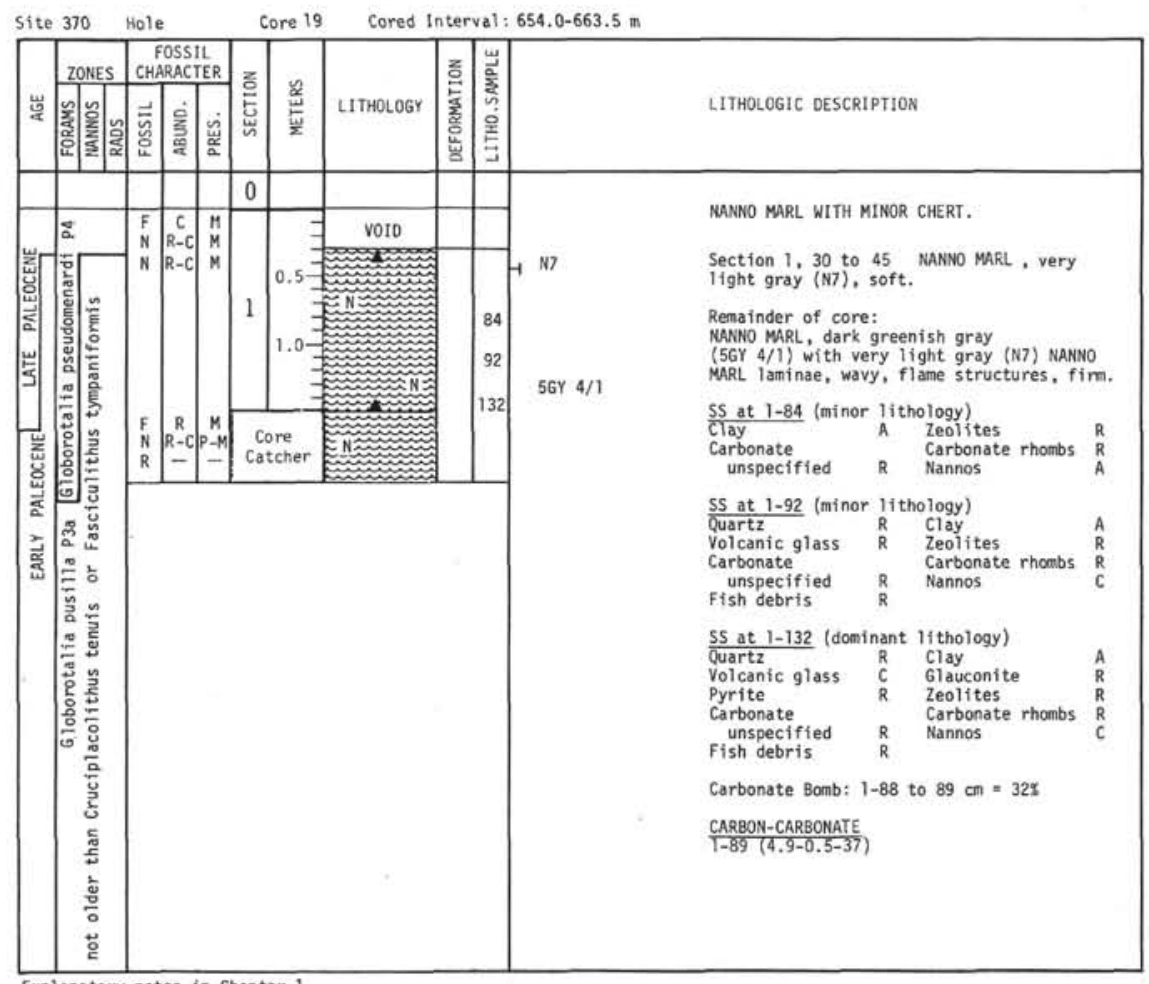



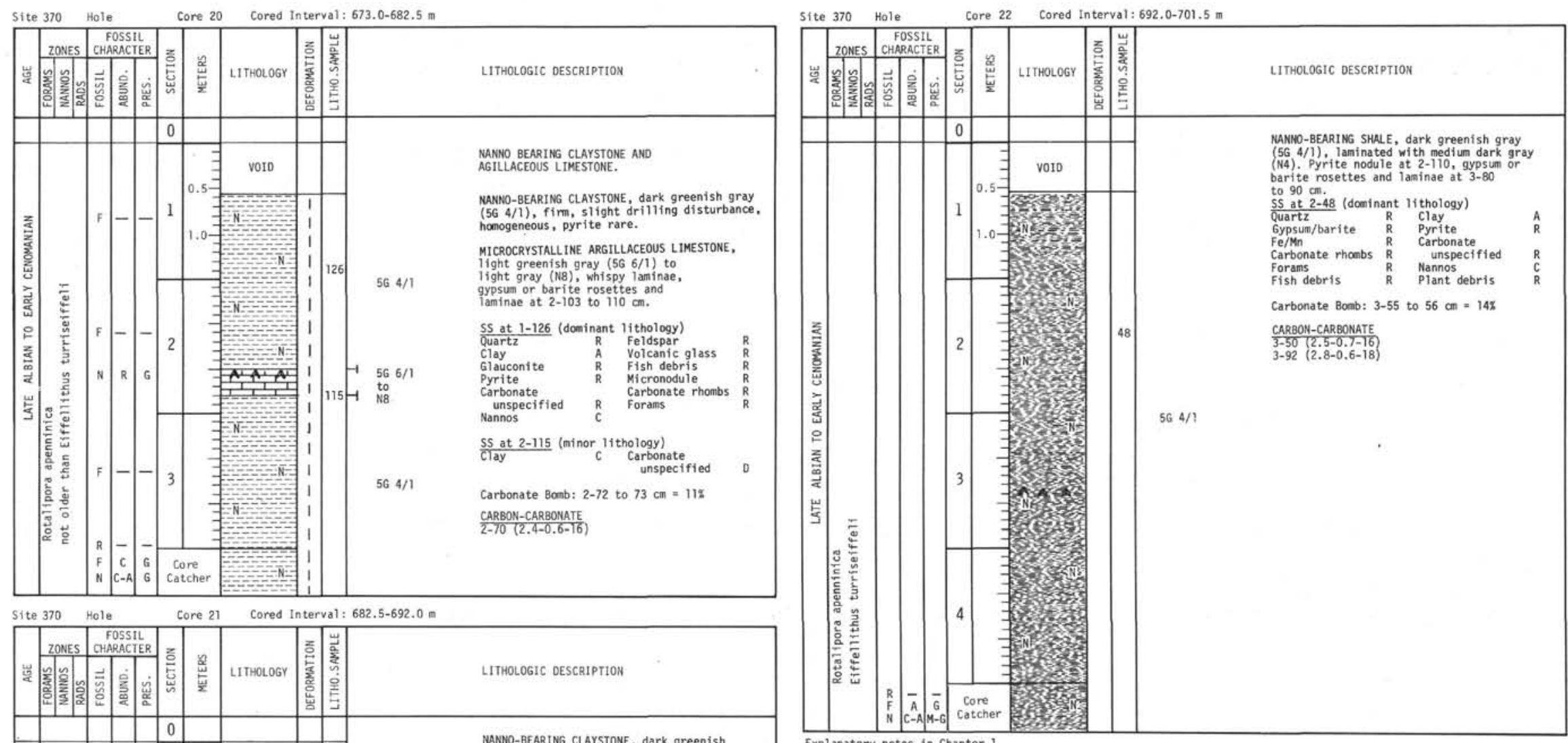

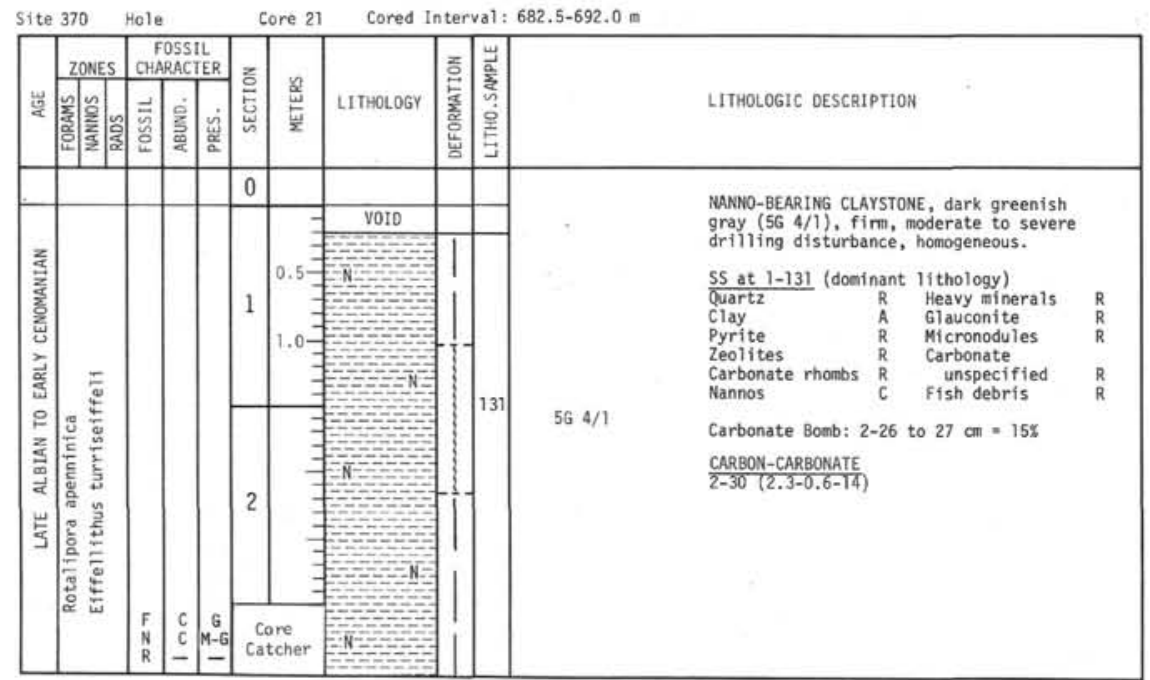




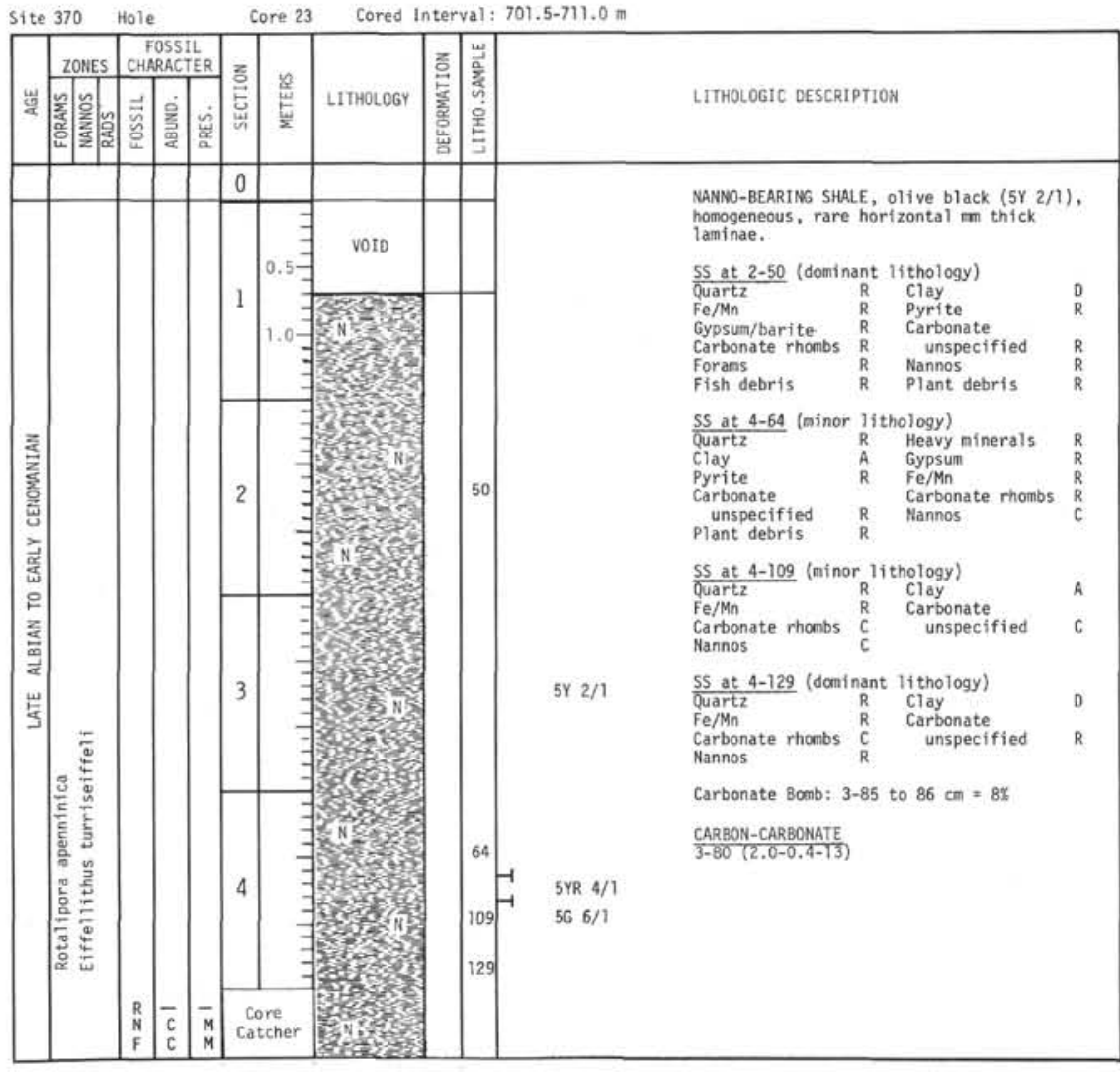

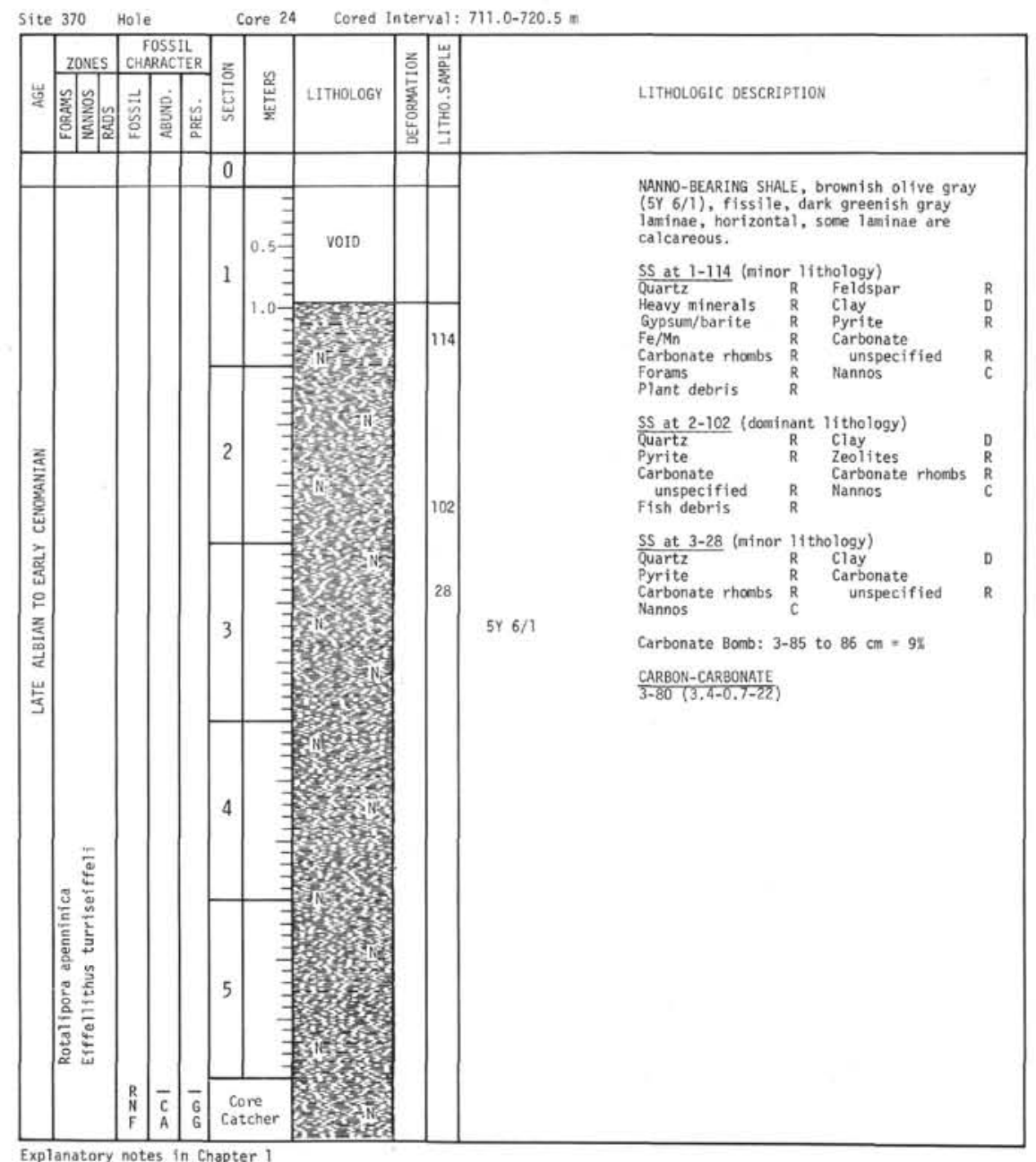




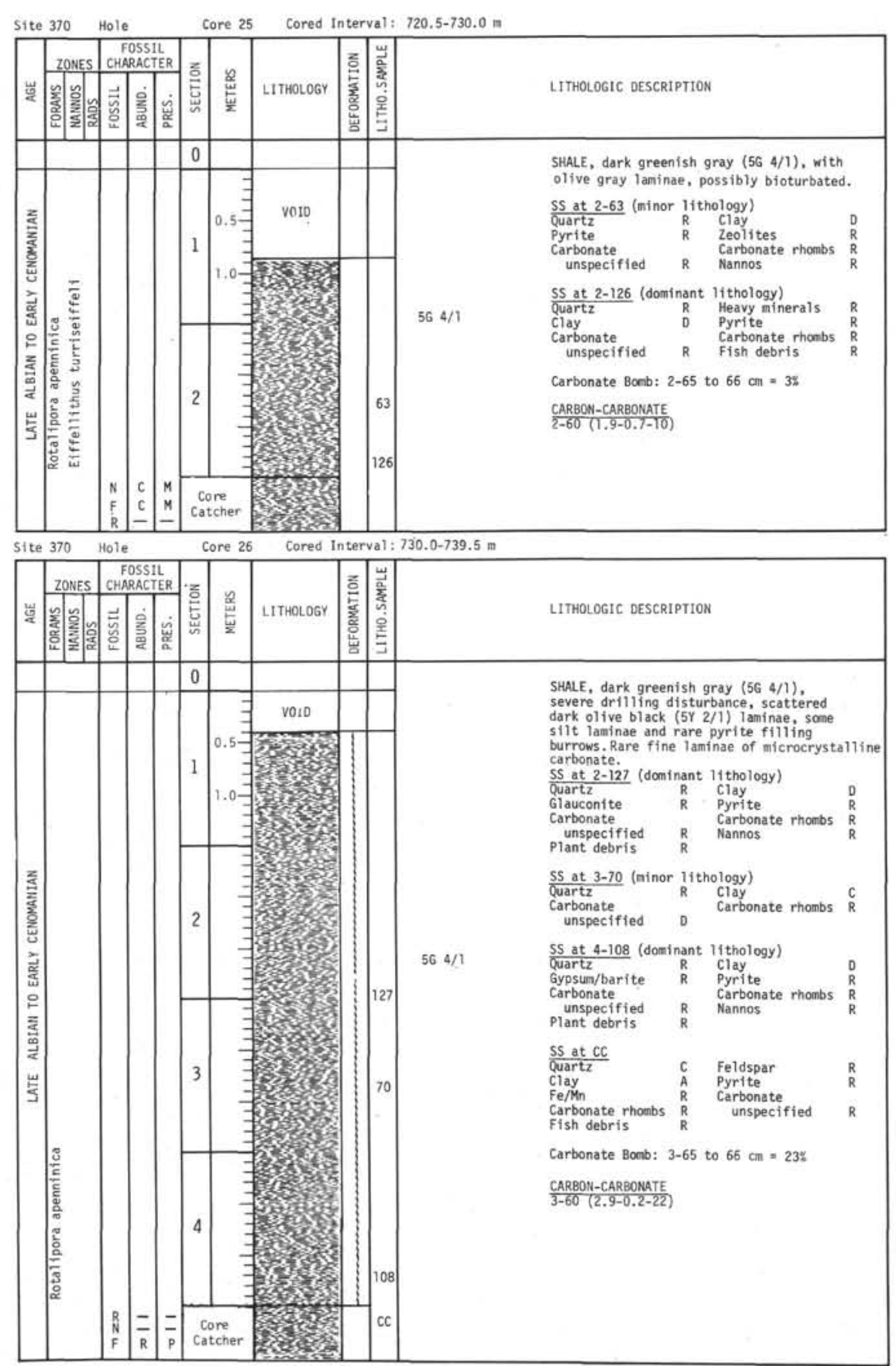

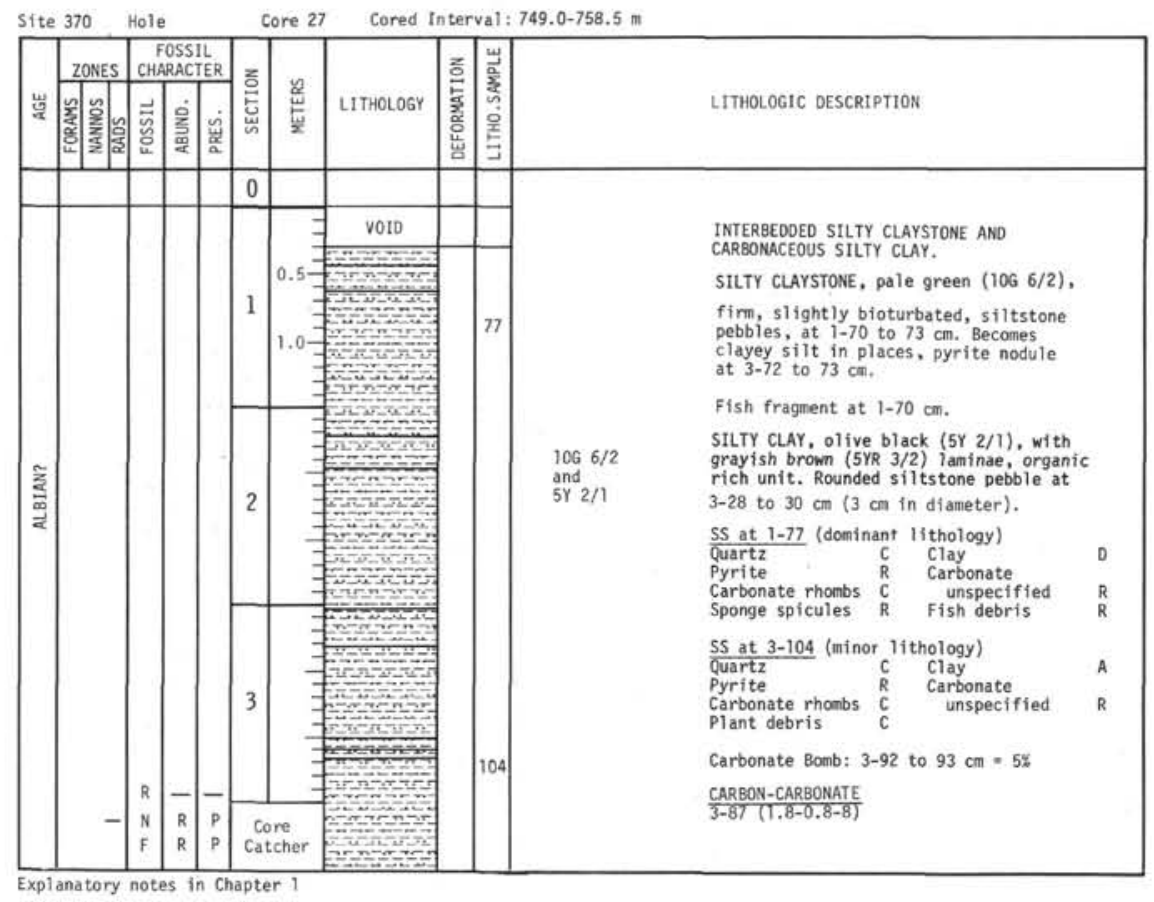



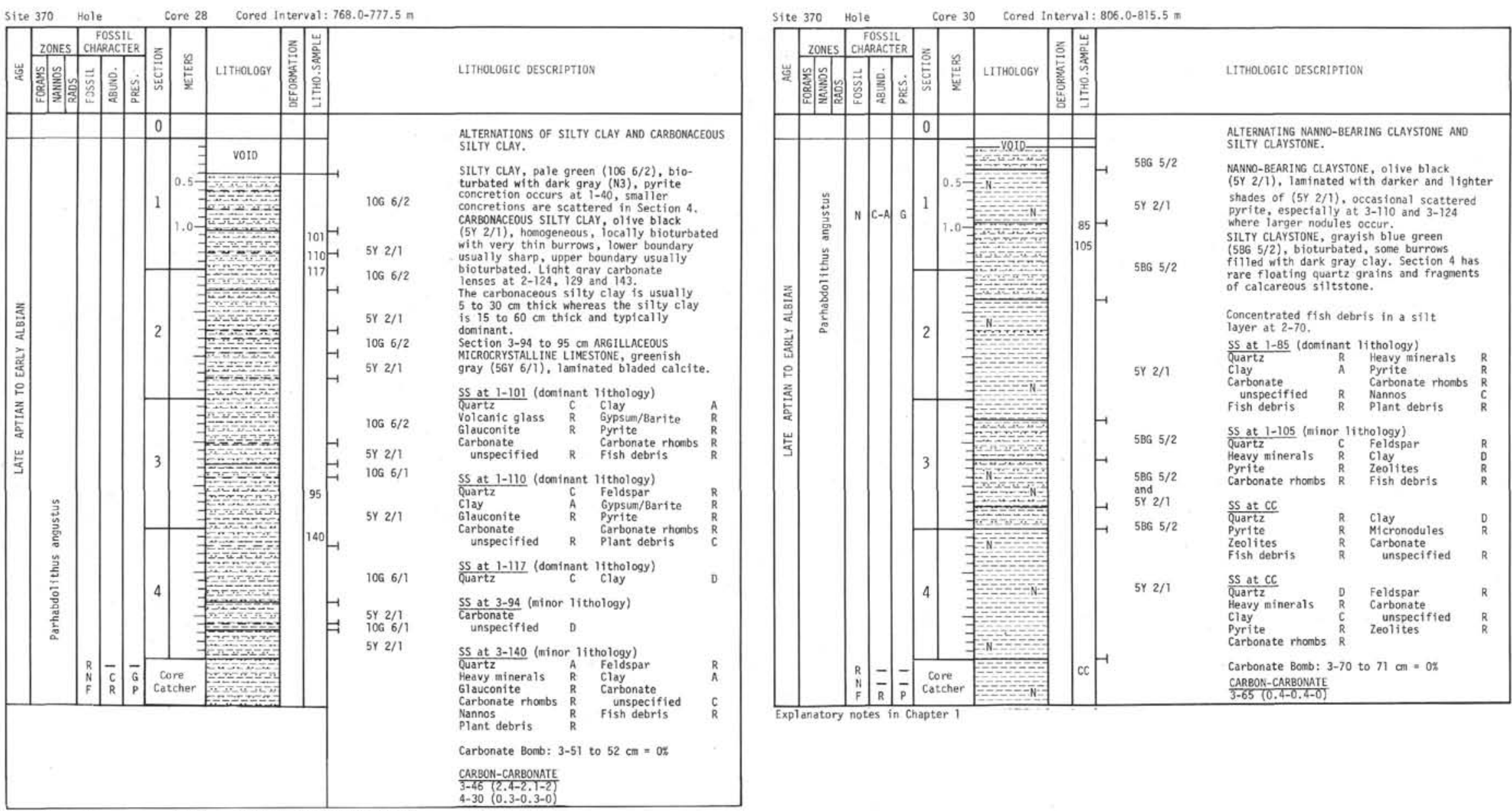

\begin{tabular}{|l|l|l|l|l|l|l|l|l|}
\hline Site 370 & Hole \\
\hline
\end{tabular}

explanatory notes in Chapter 


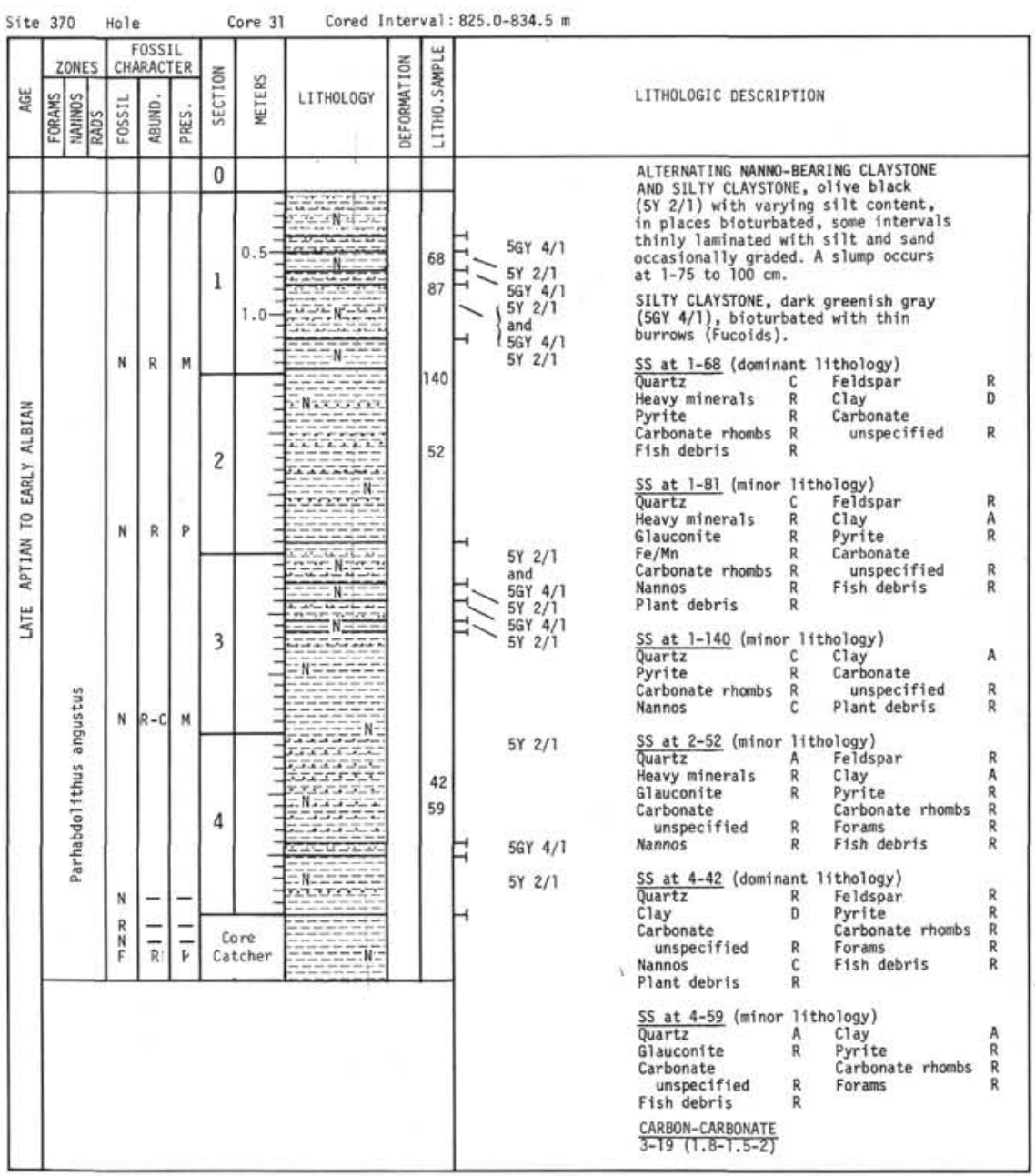

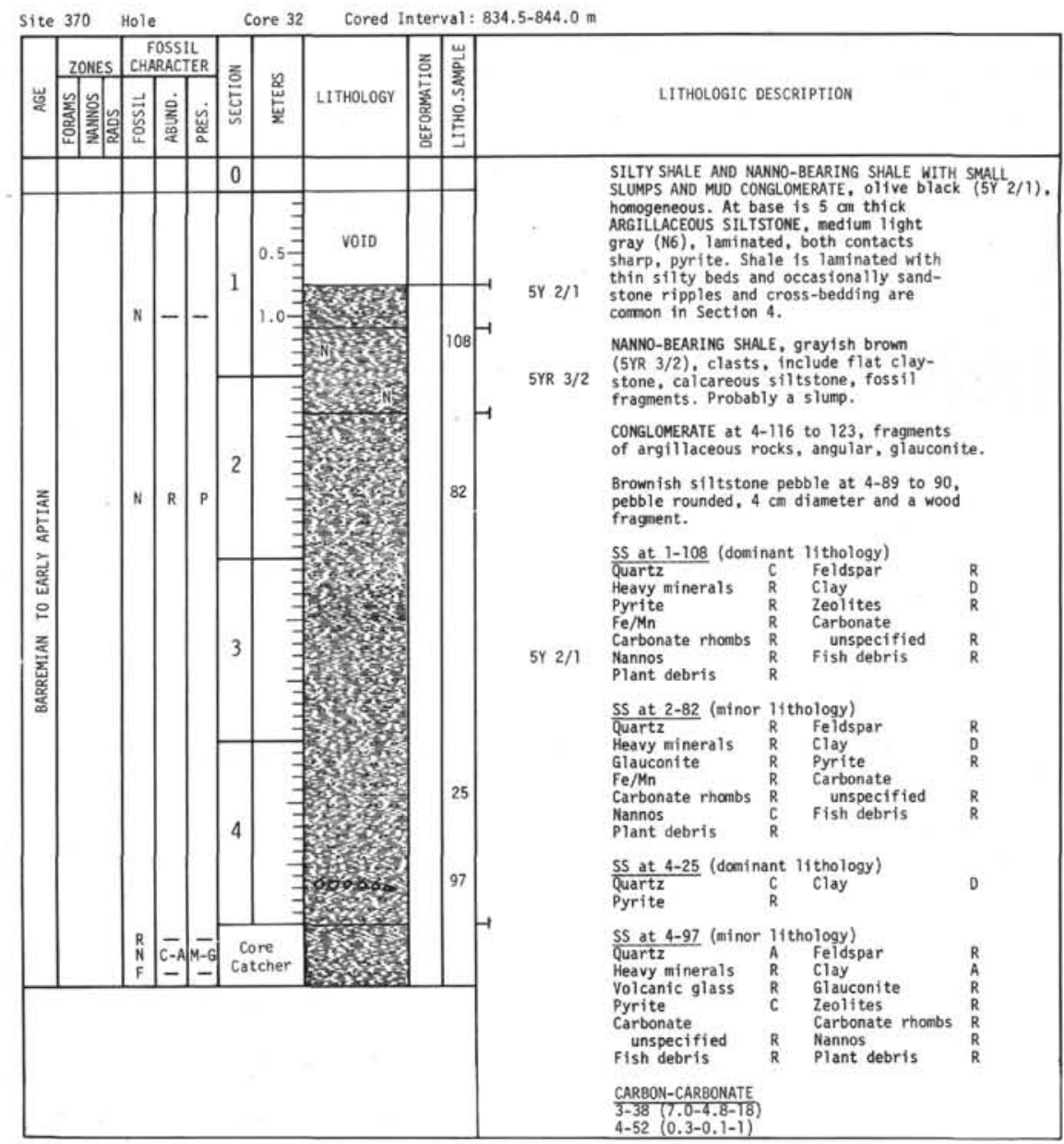

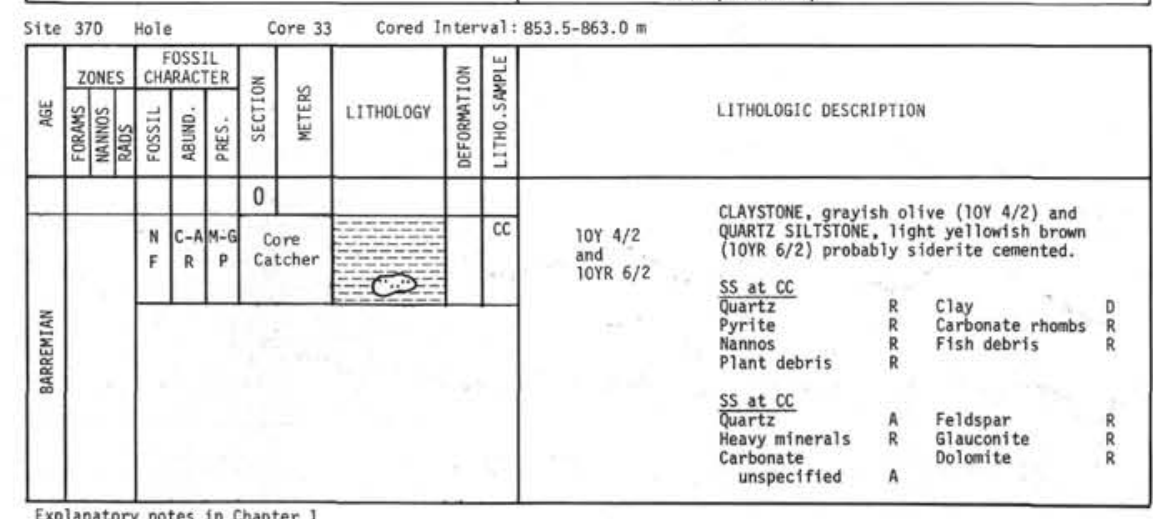




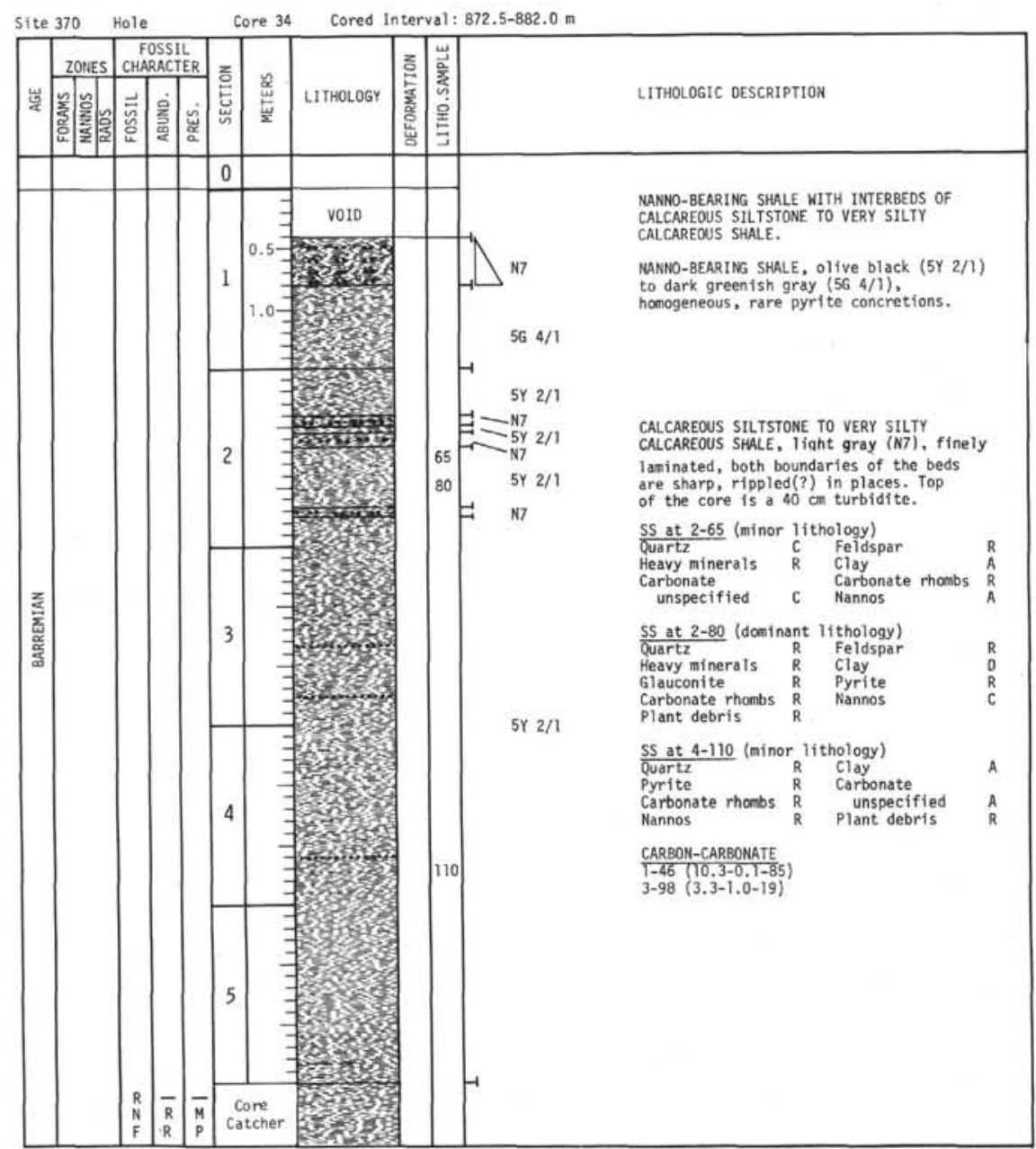

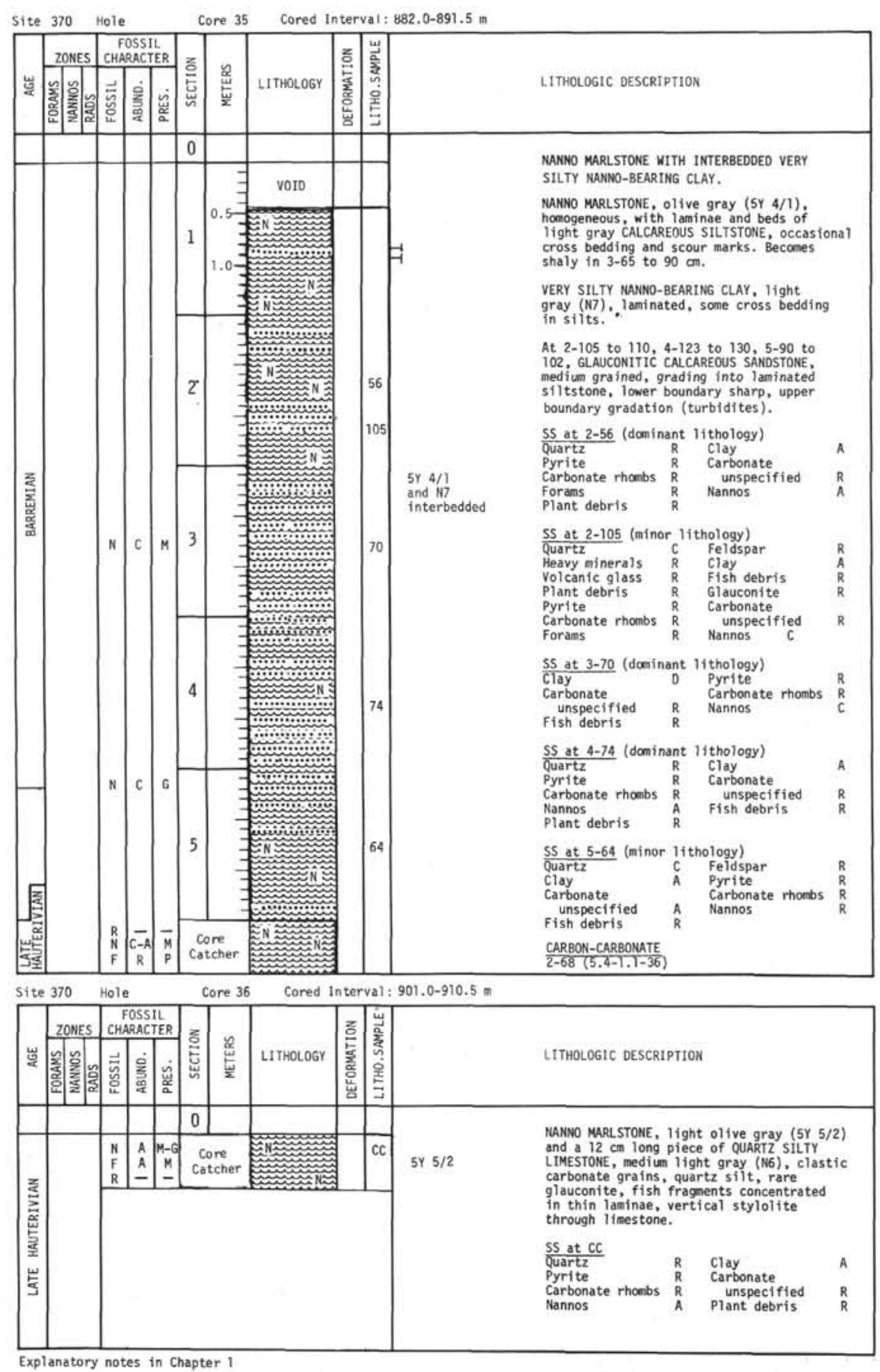




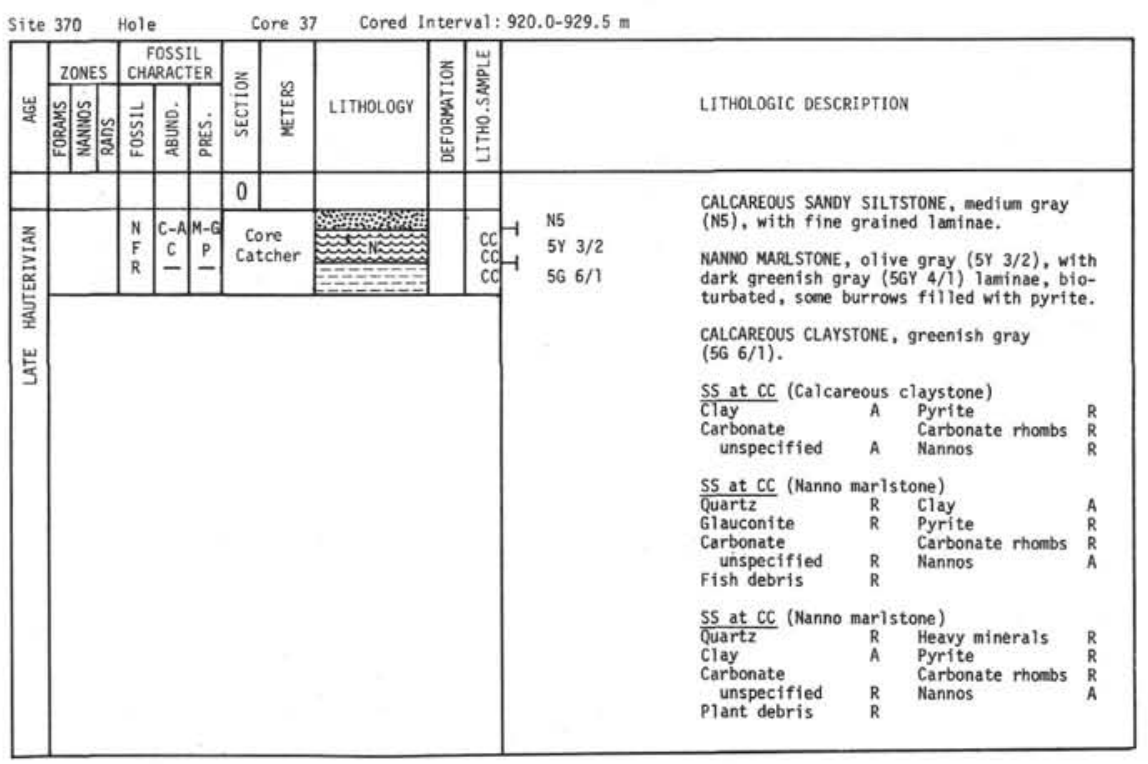

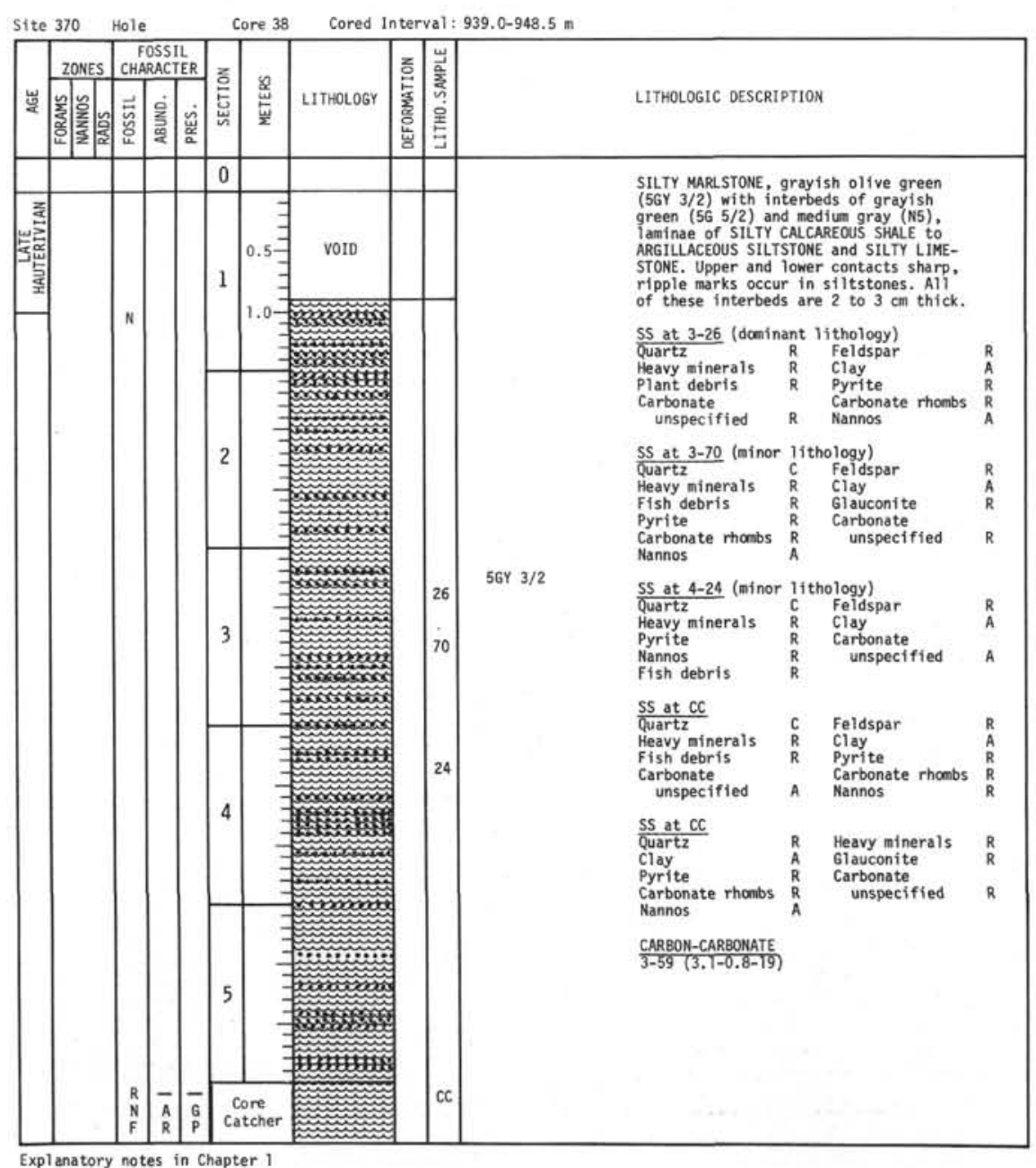




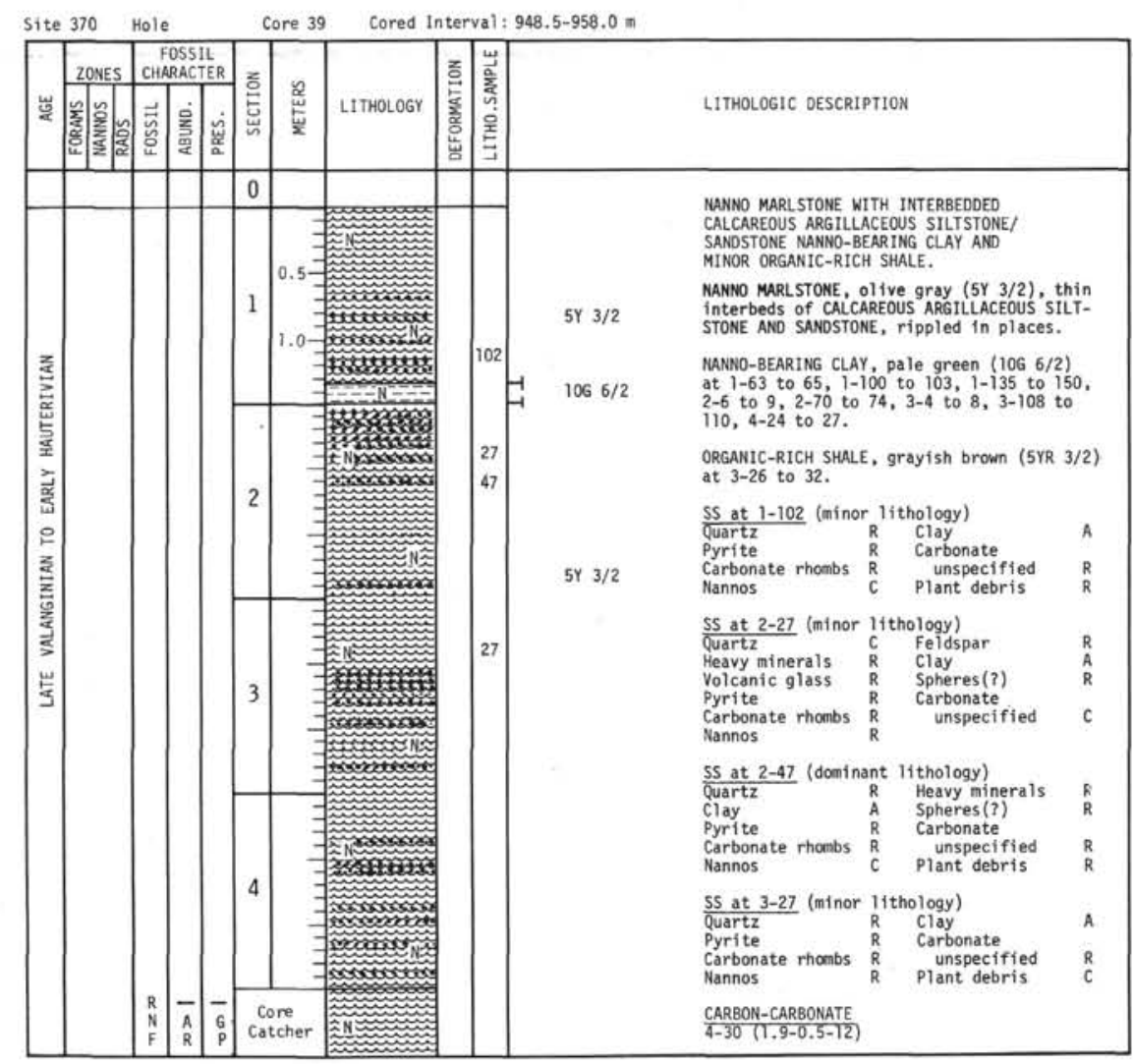

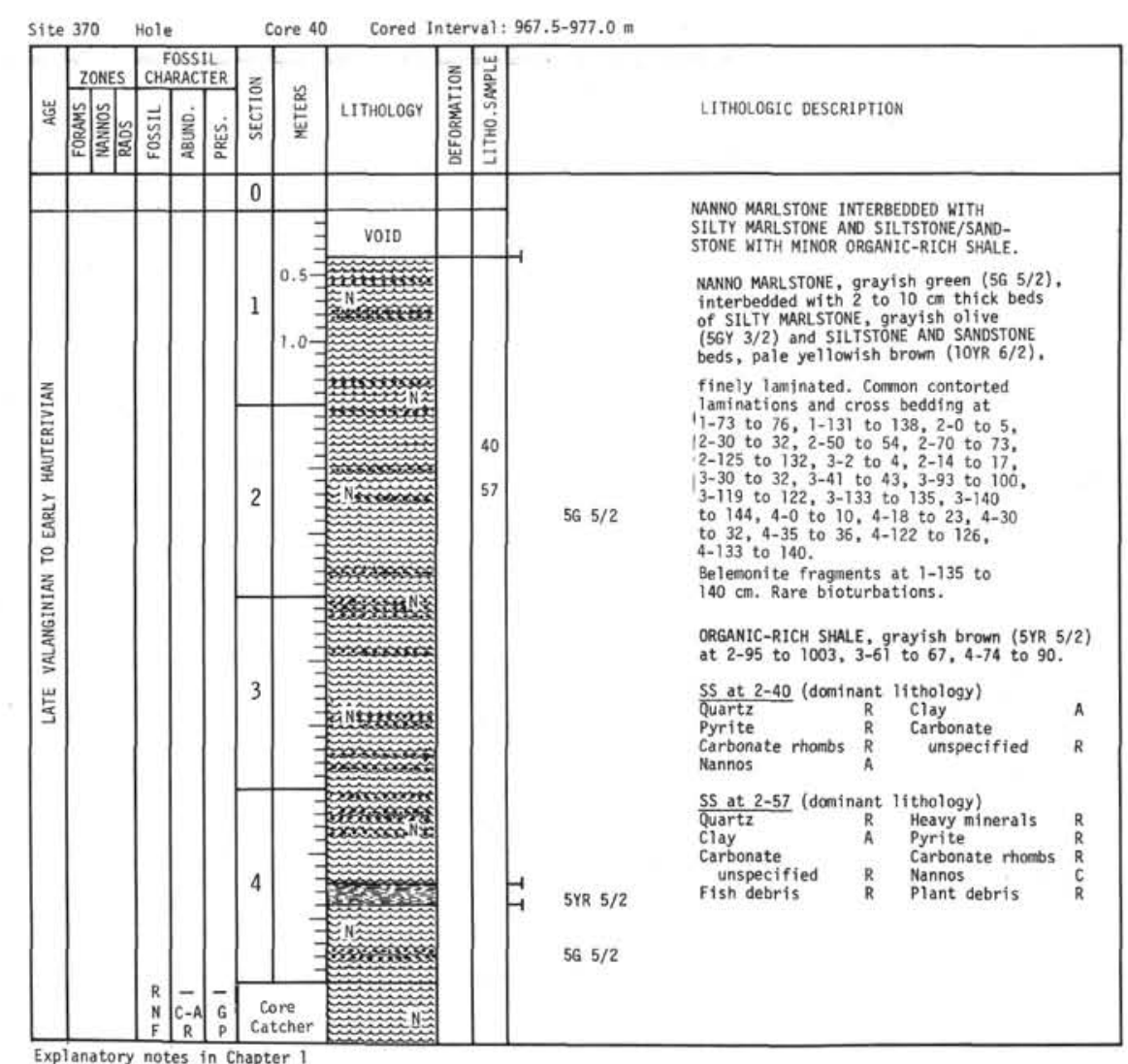




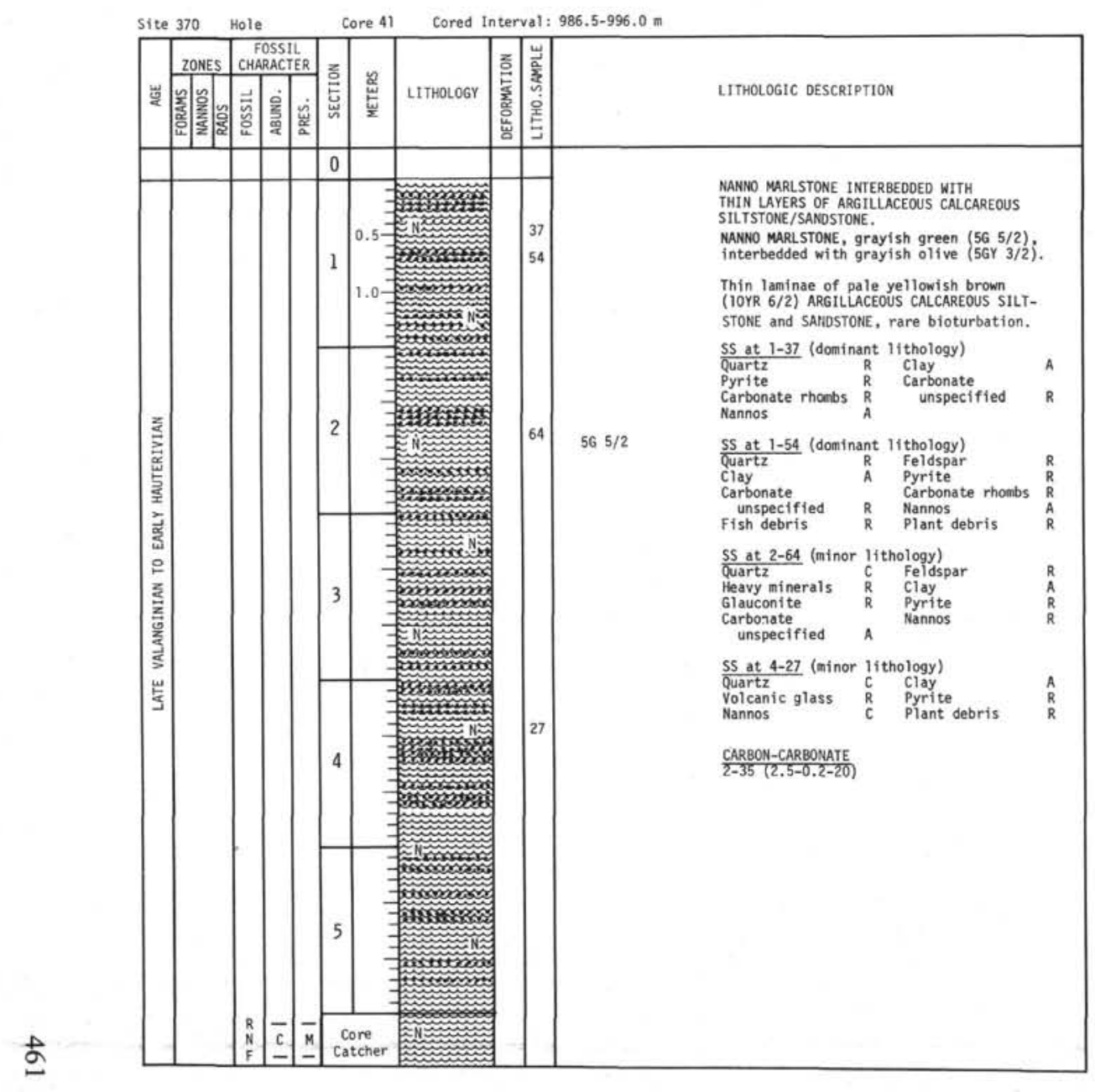

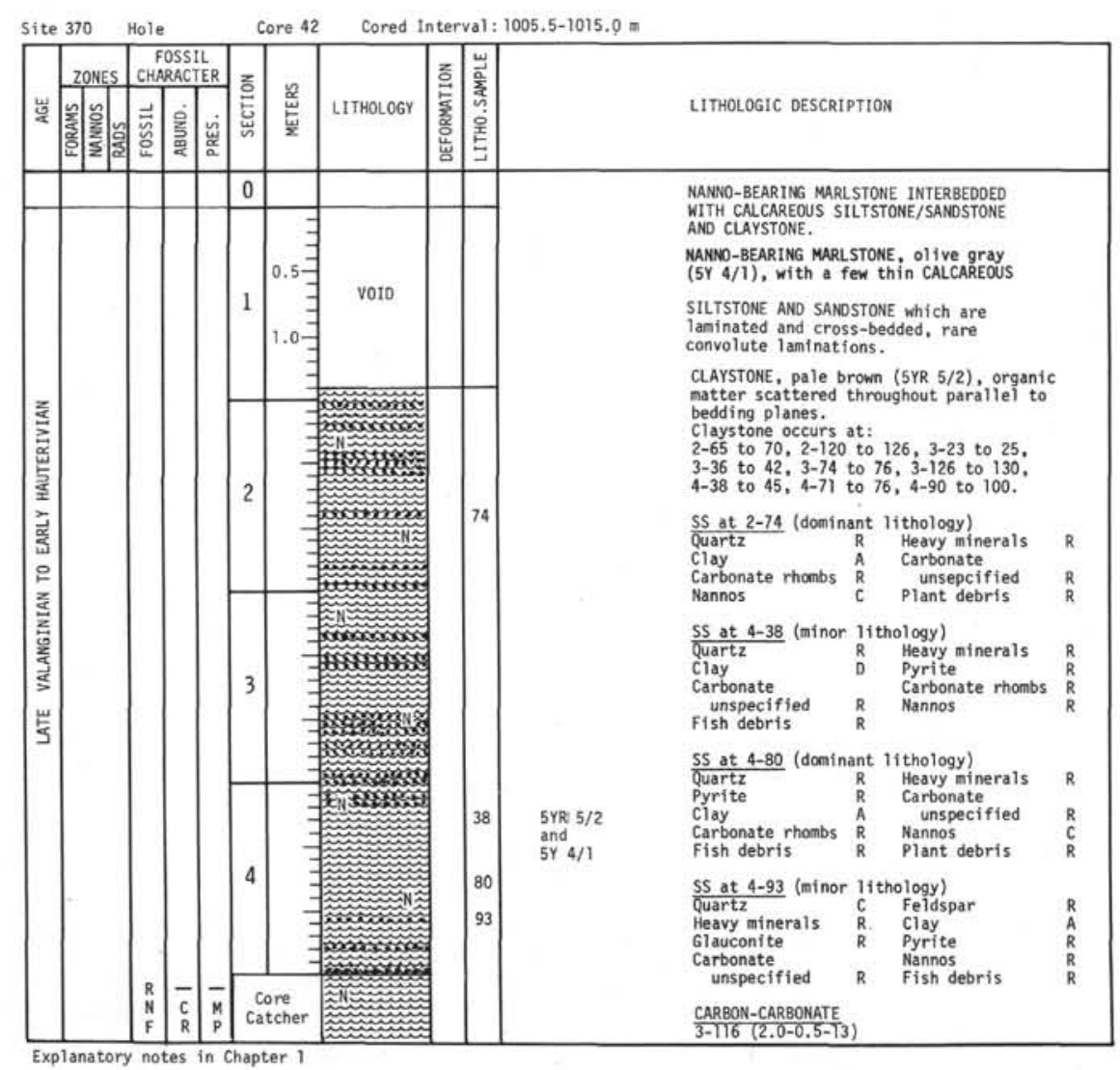




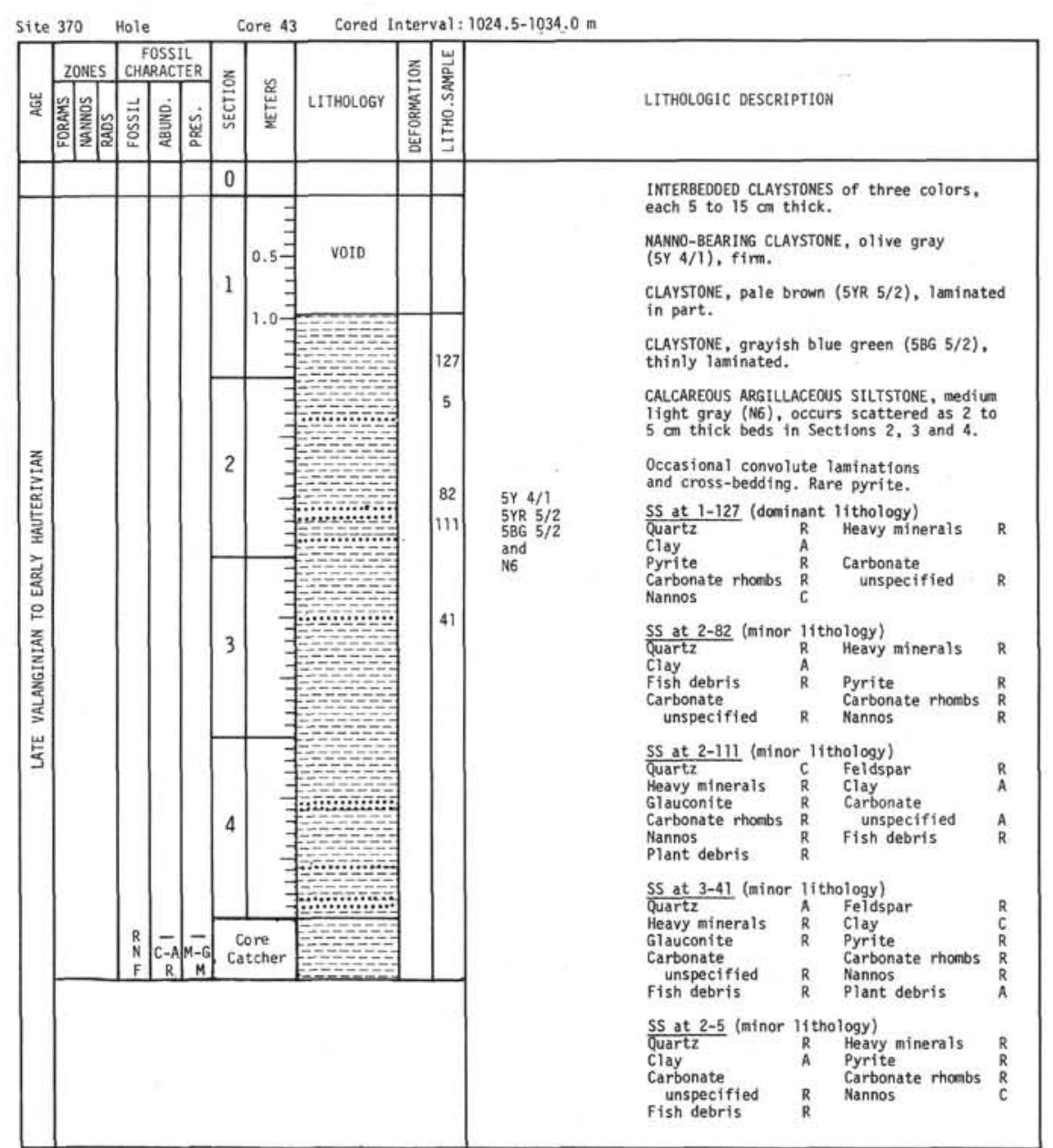

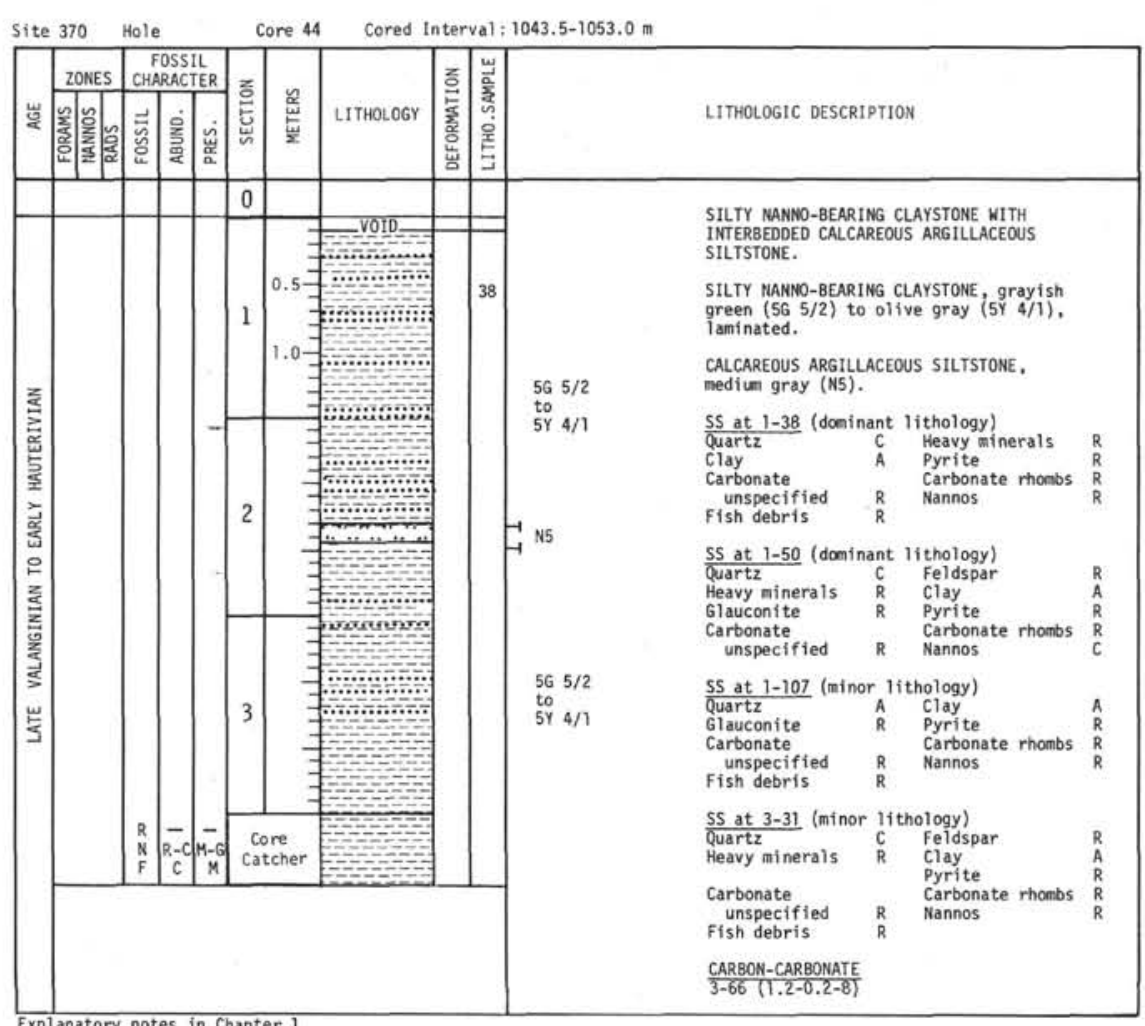




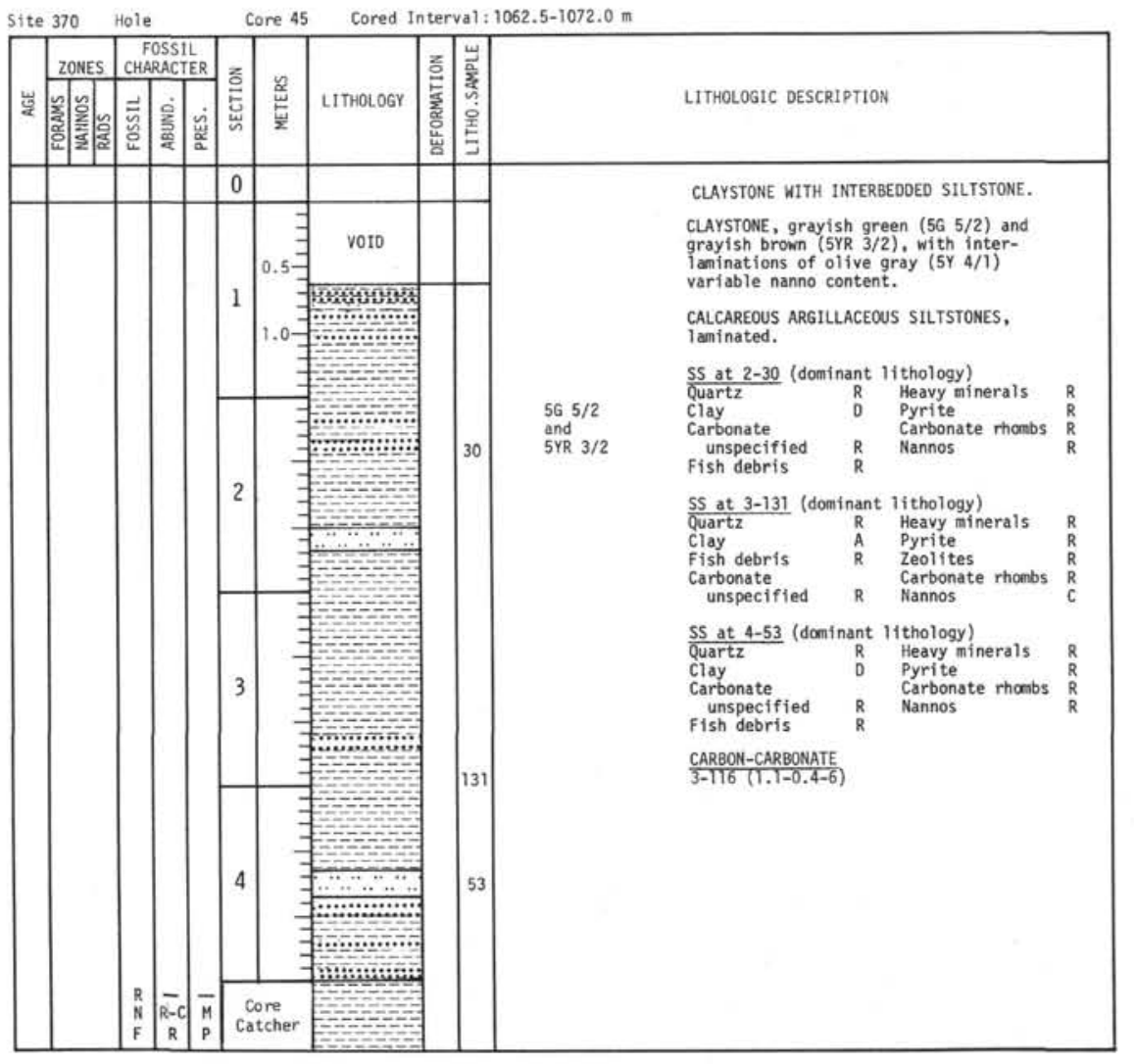

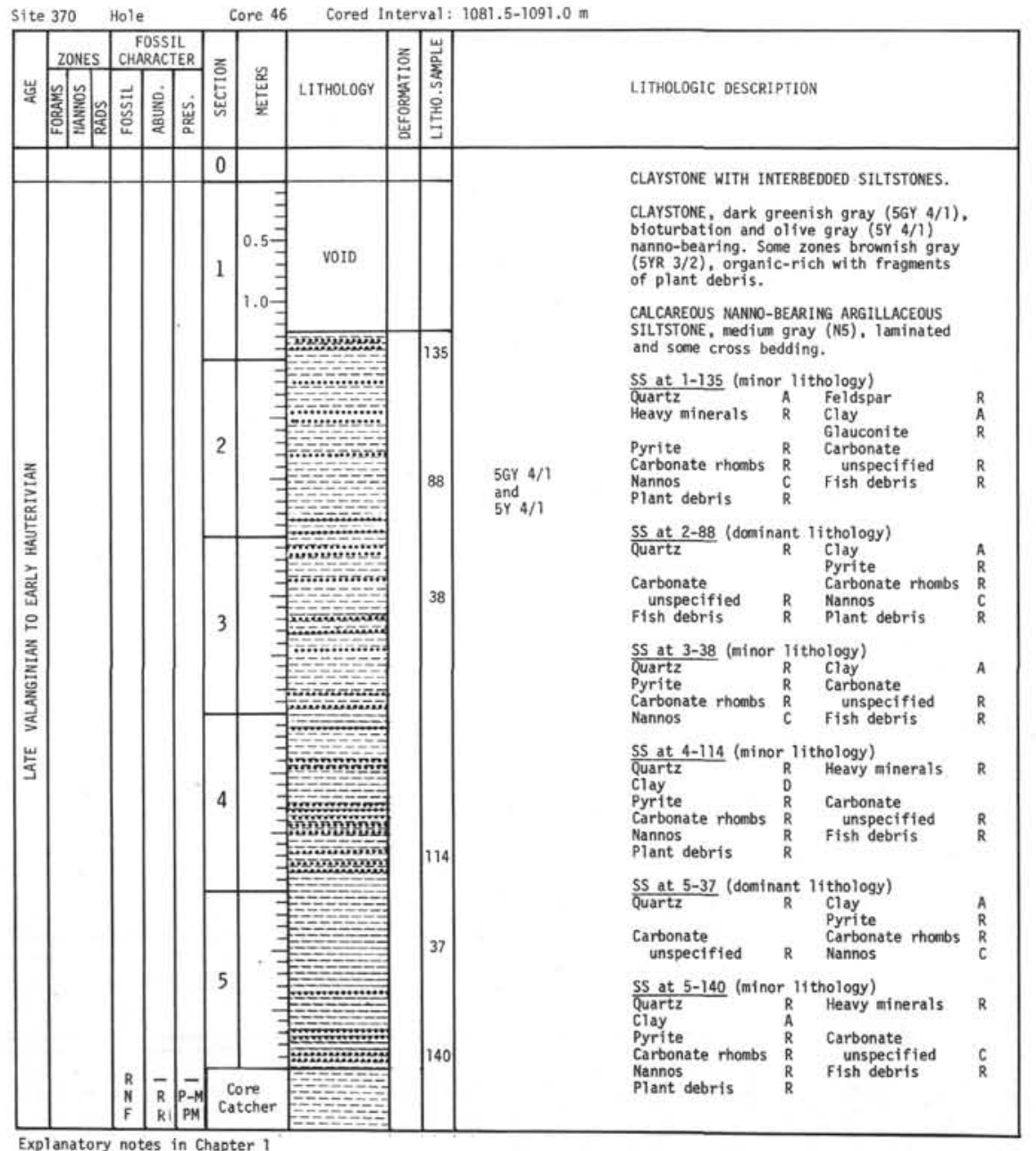




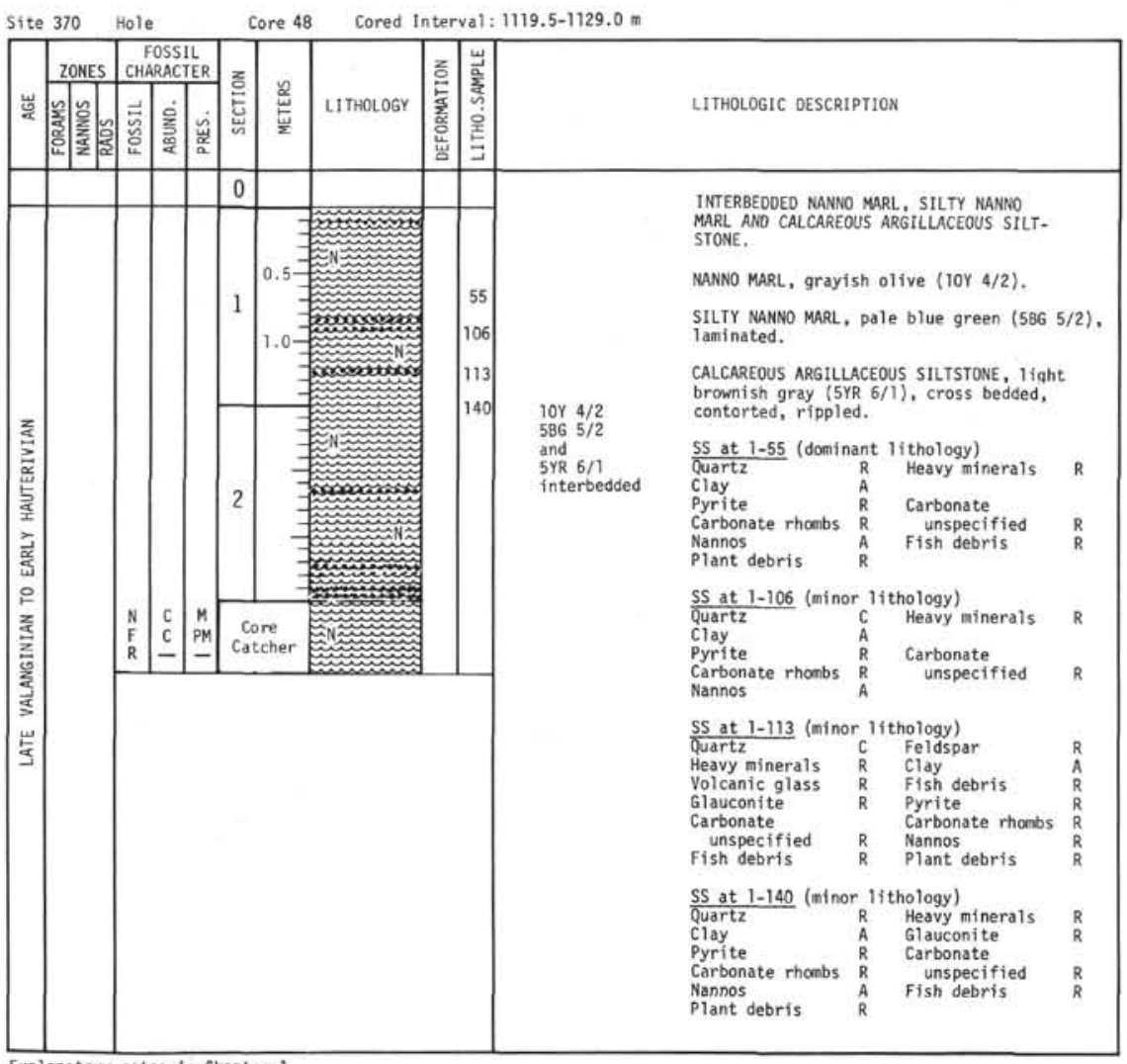




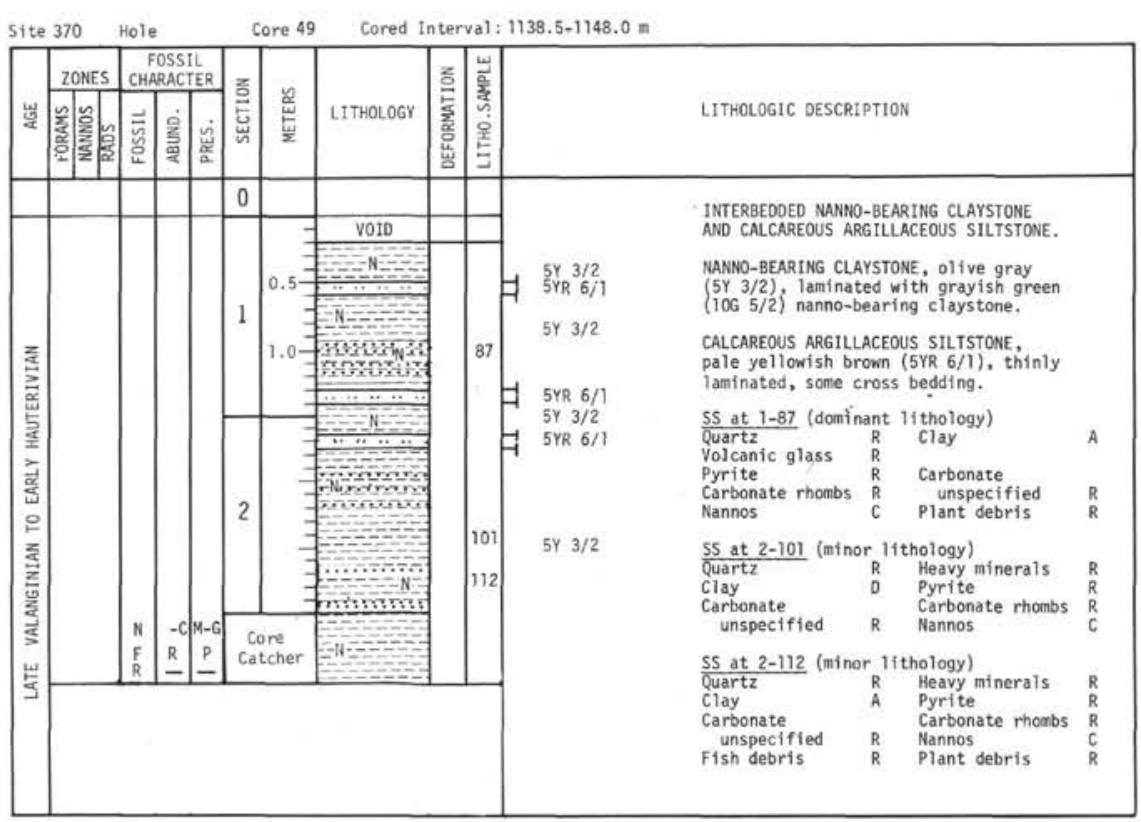

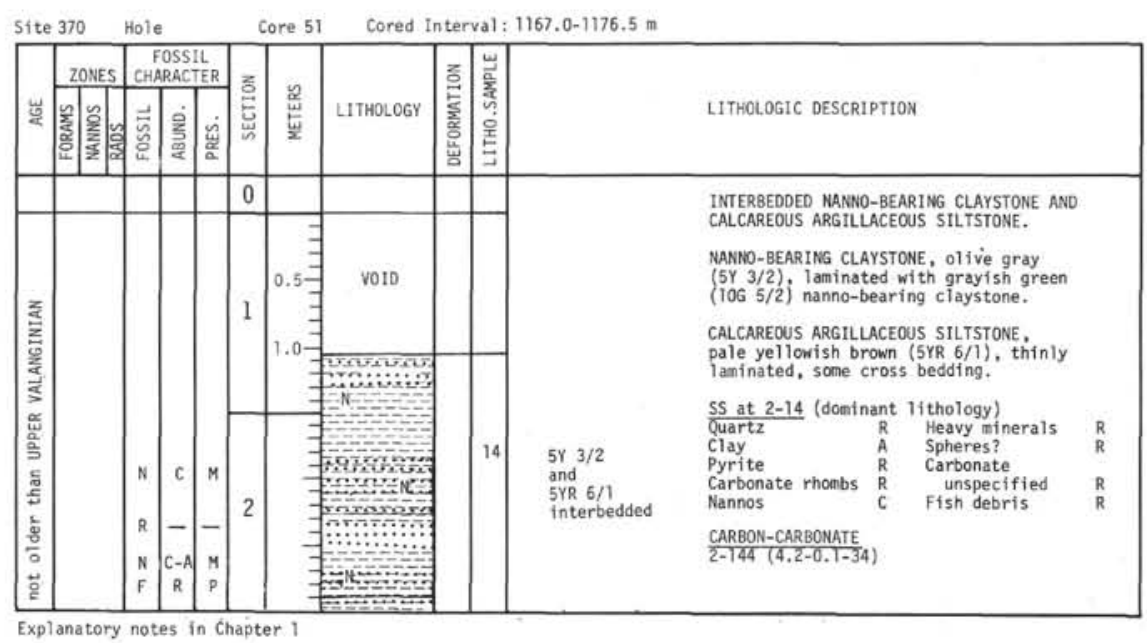

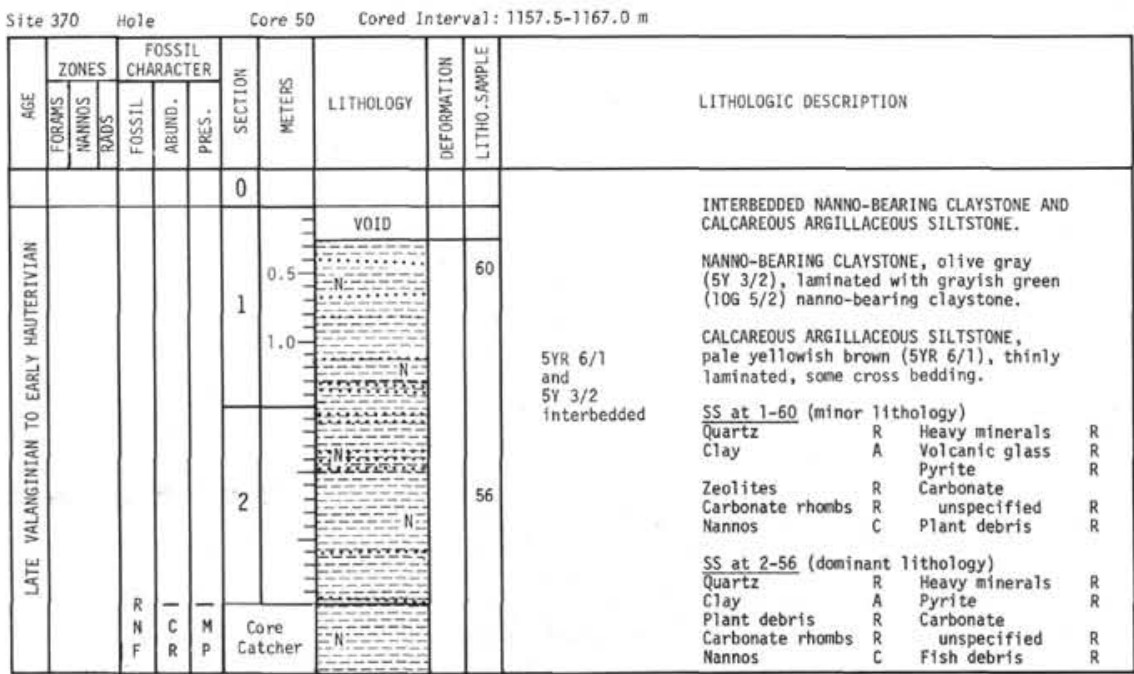


SITE 370: DEEP BASIN OFF MOROCCO

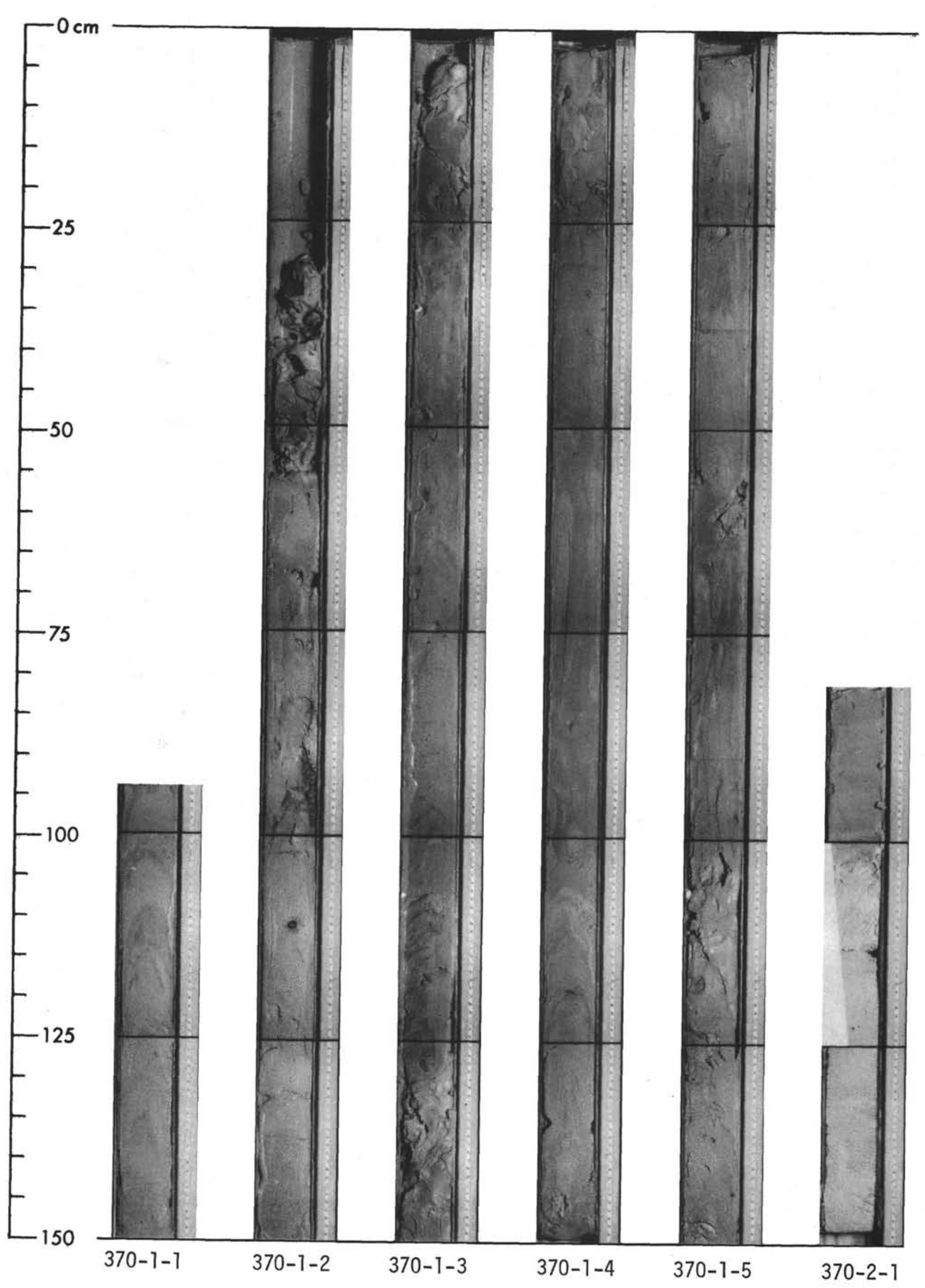




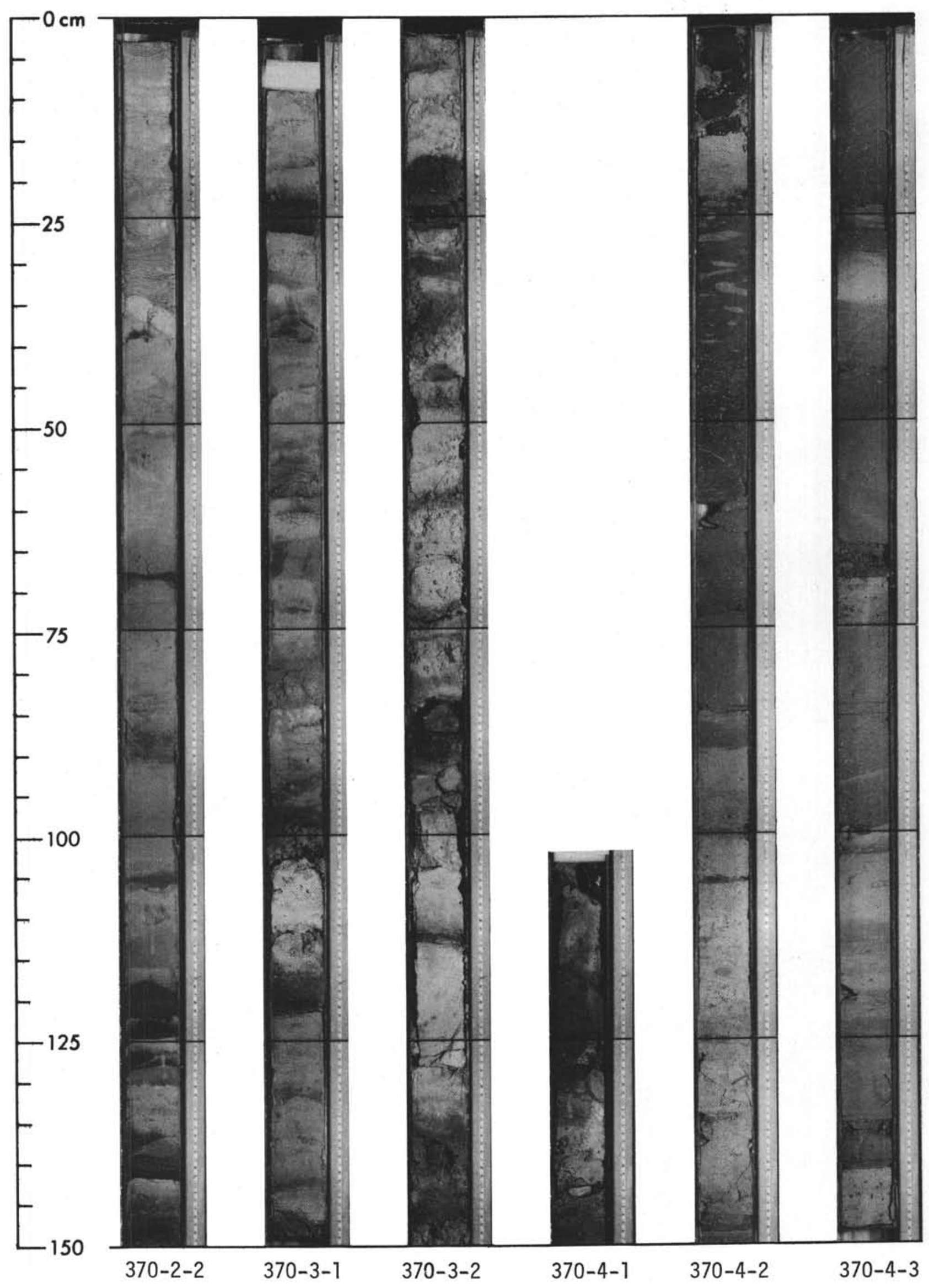


SITE 370: DEEP BASIN OFF MOROCCO

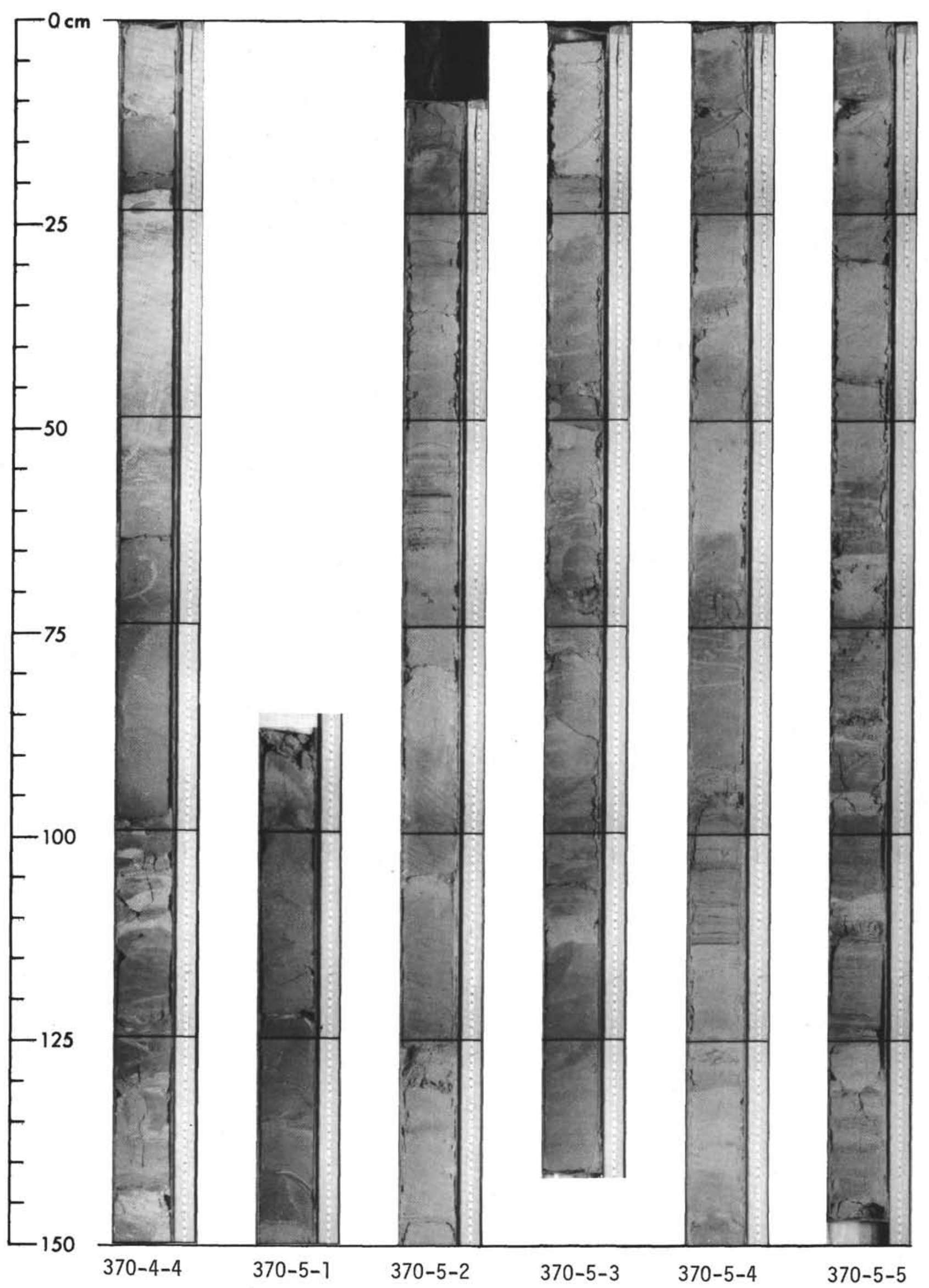




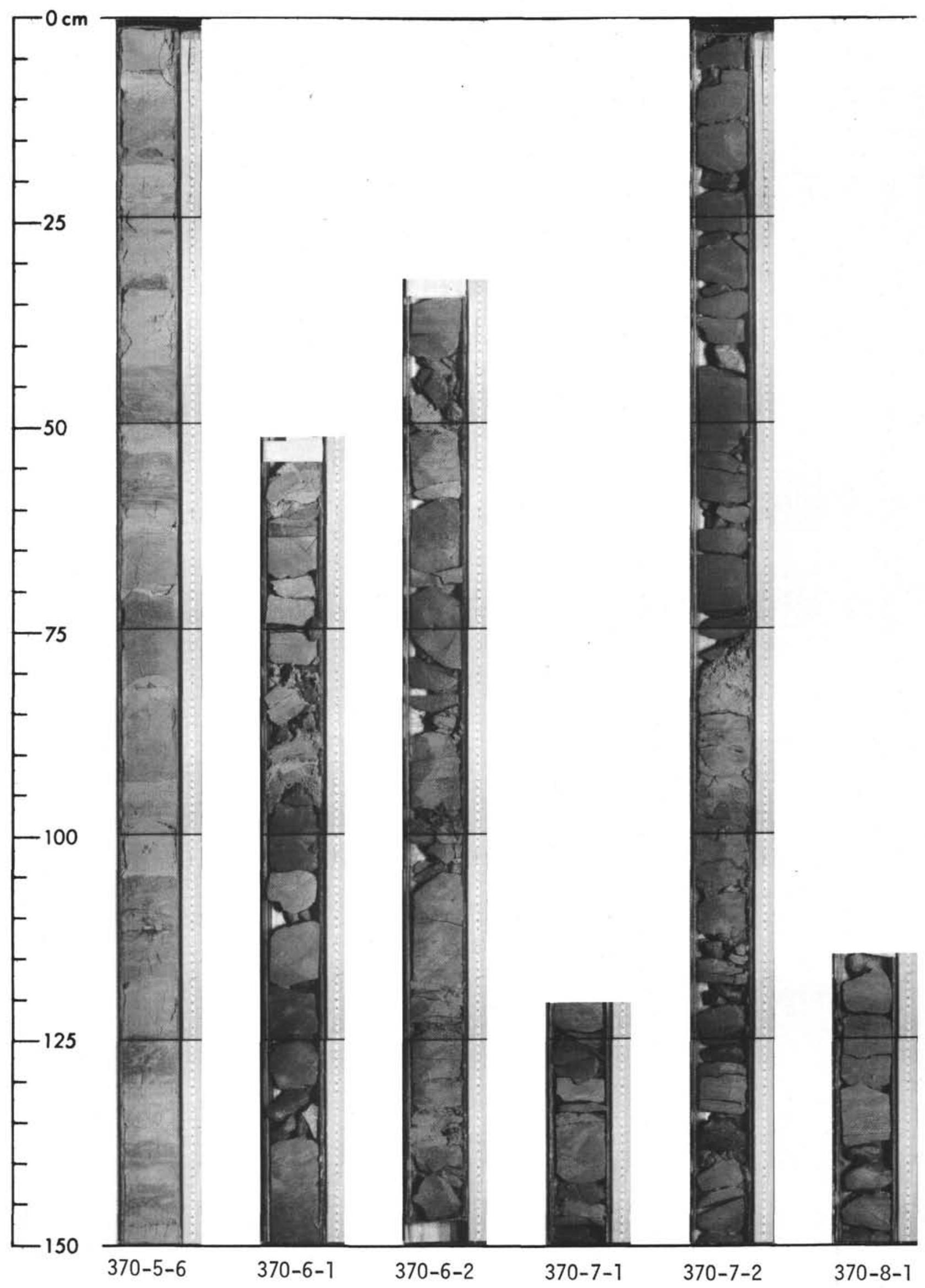




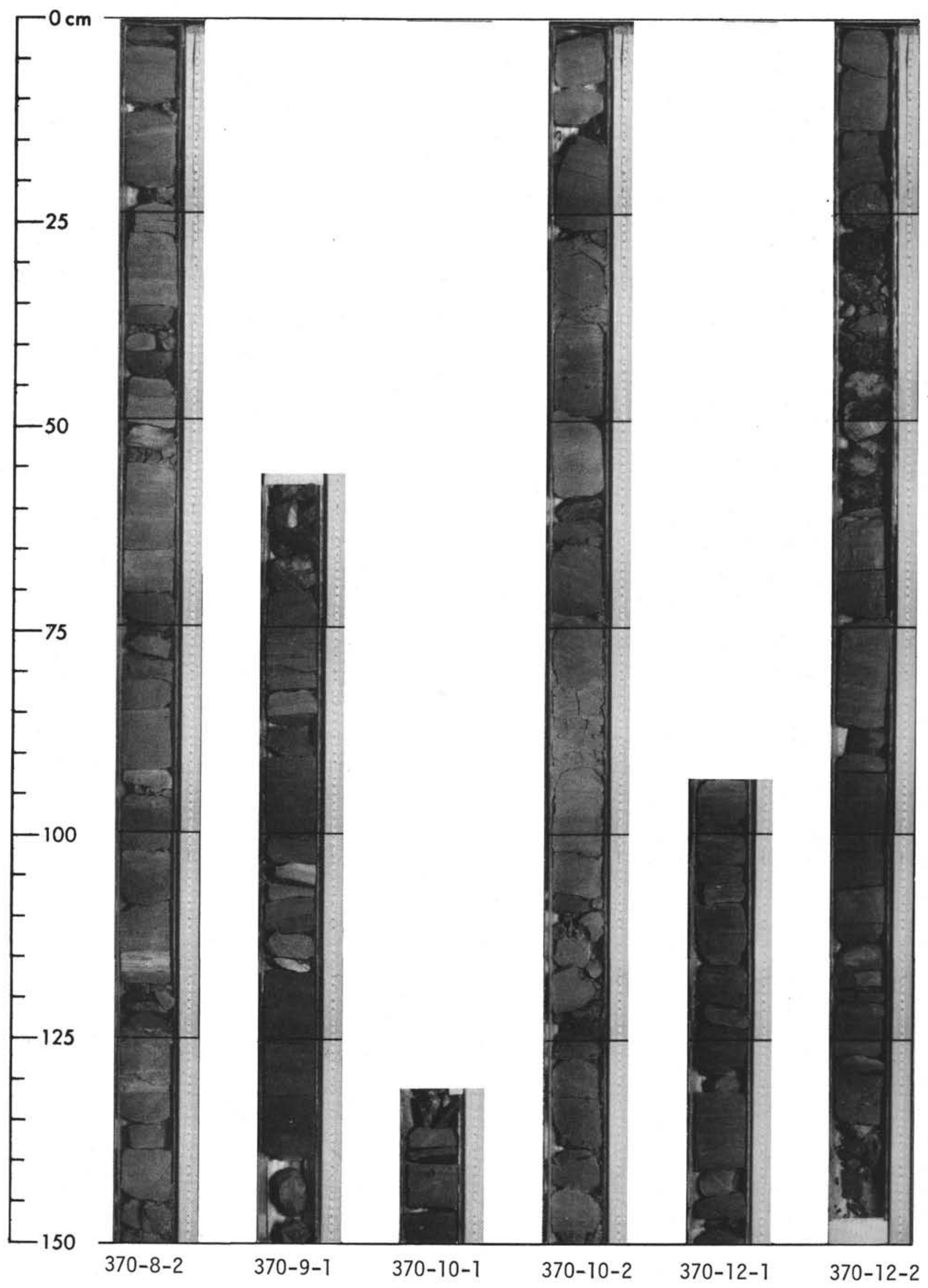




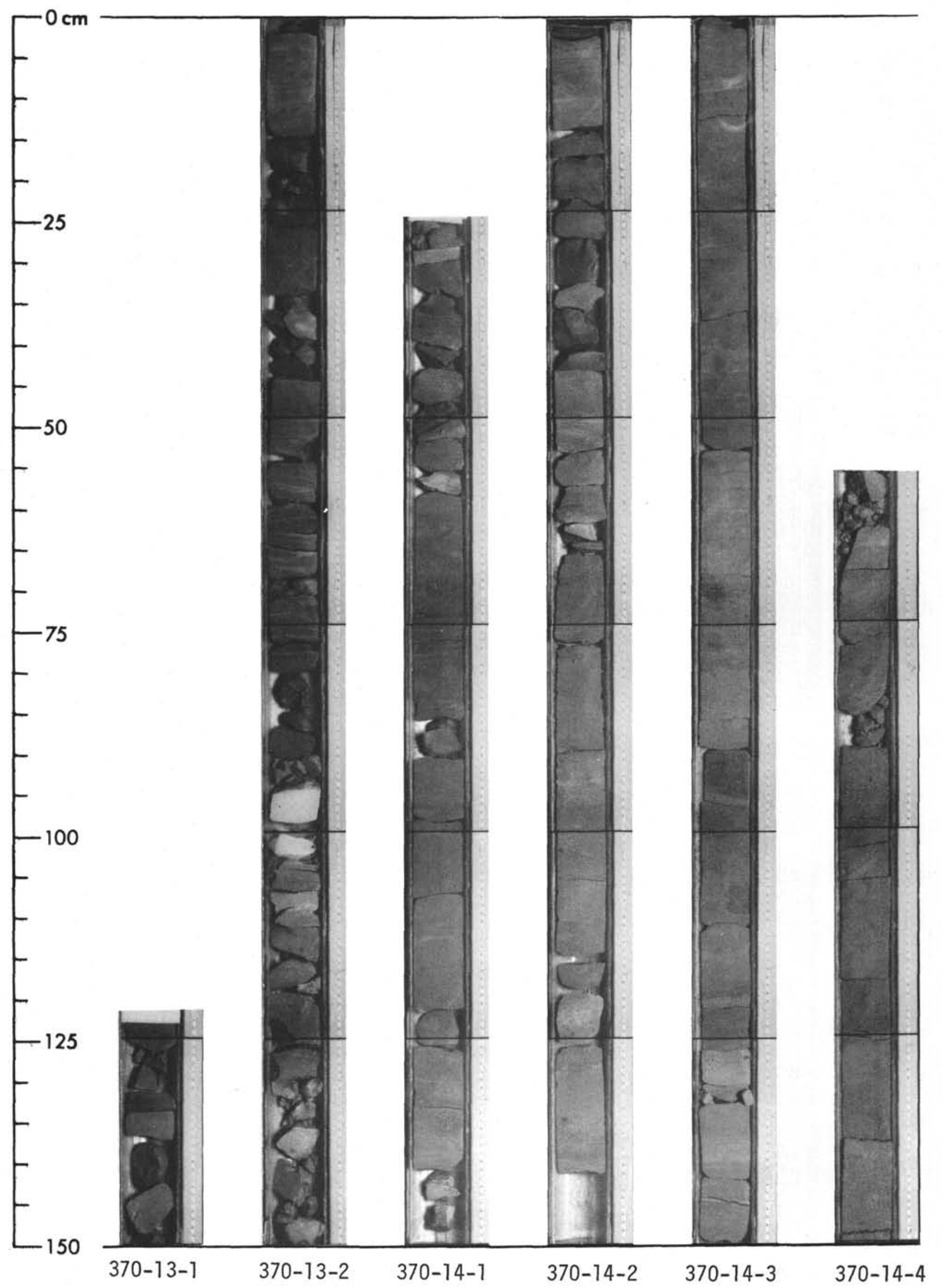




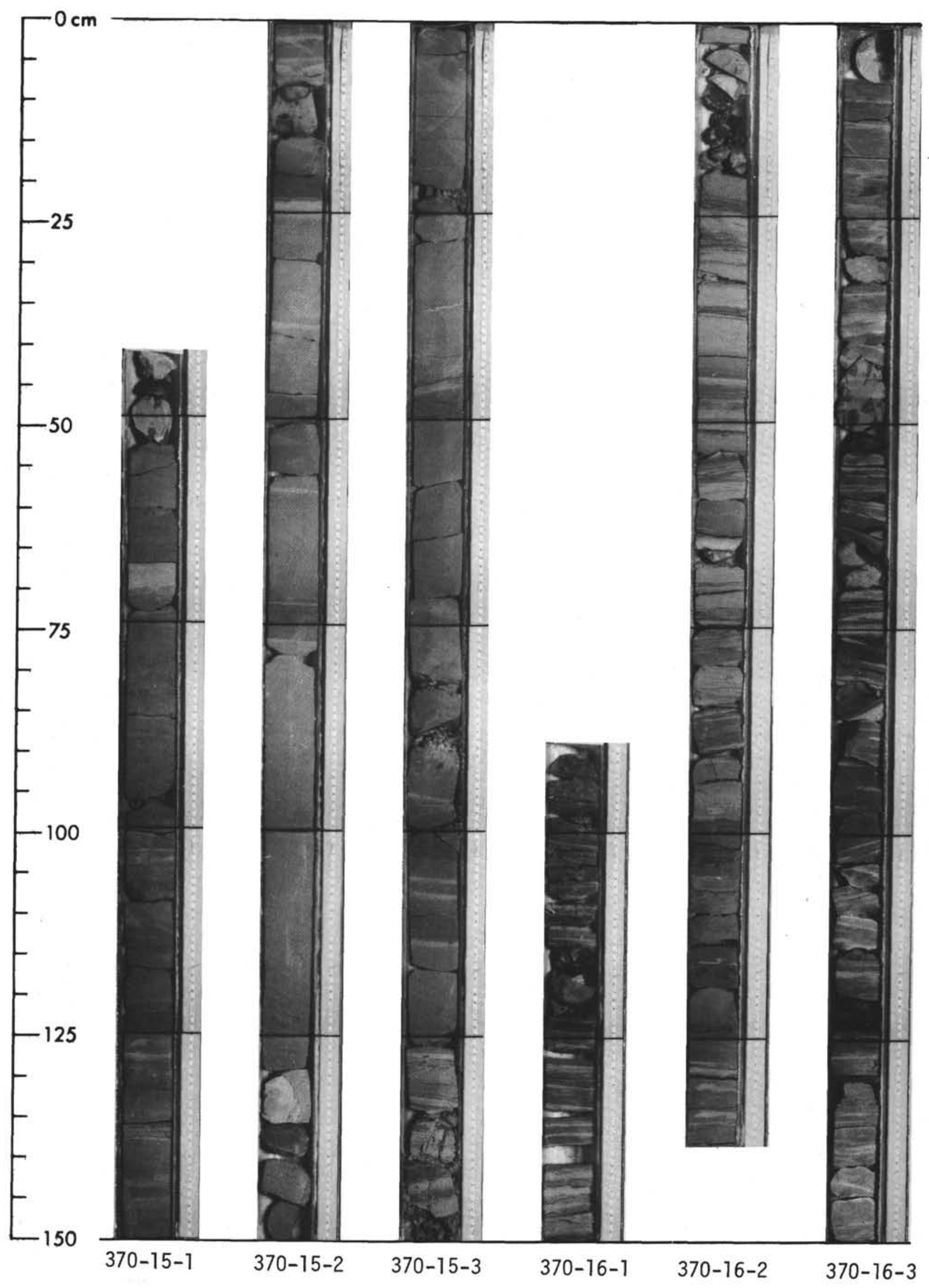




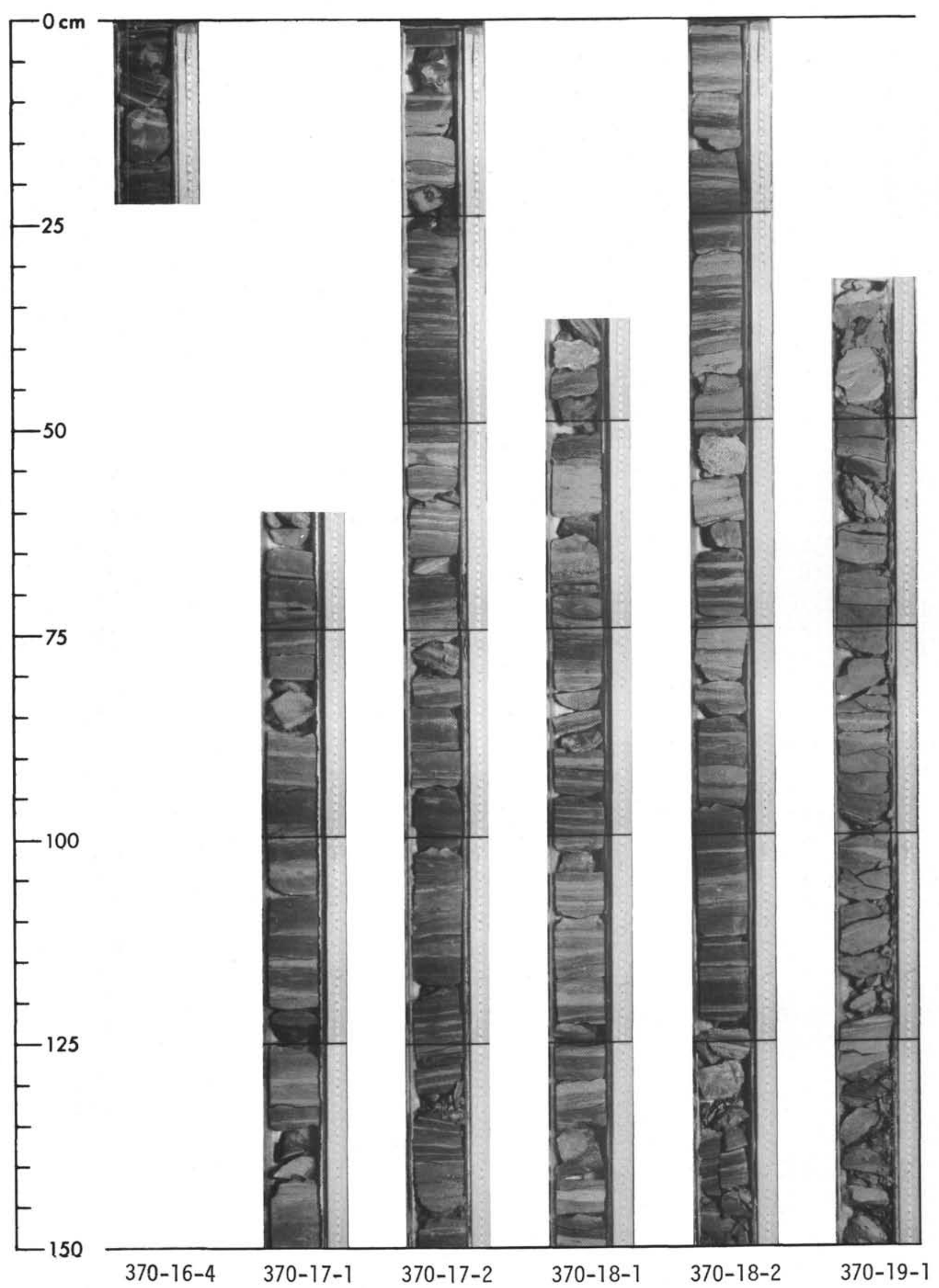




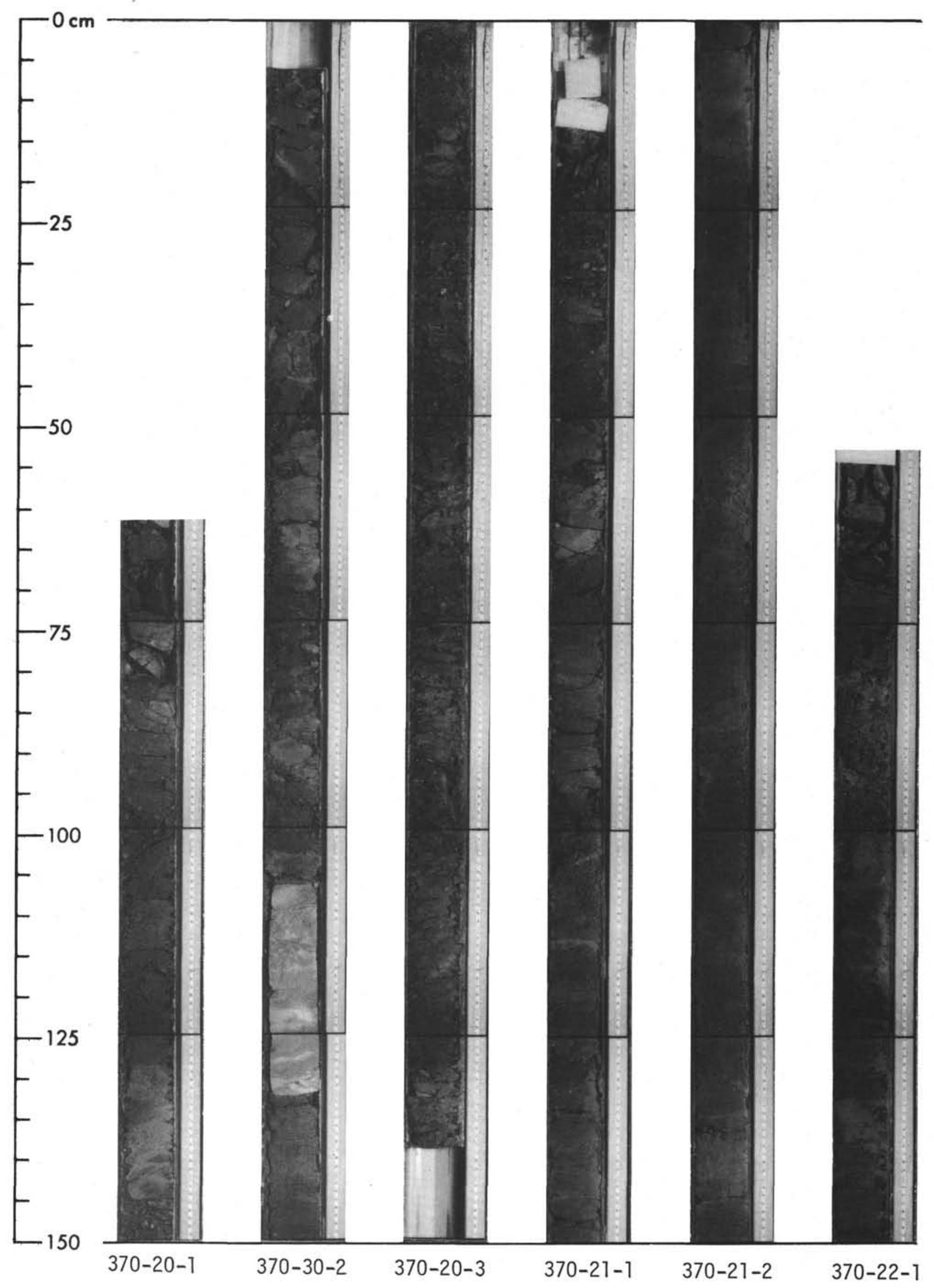




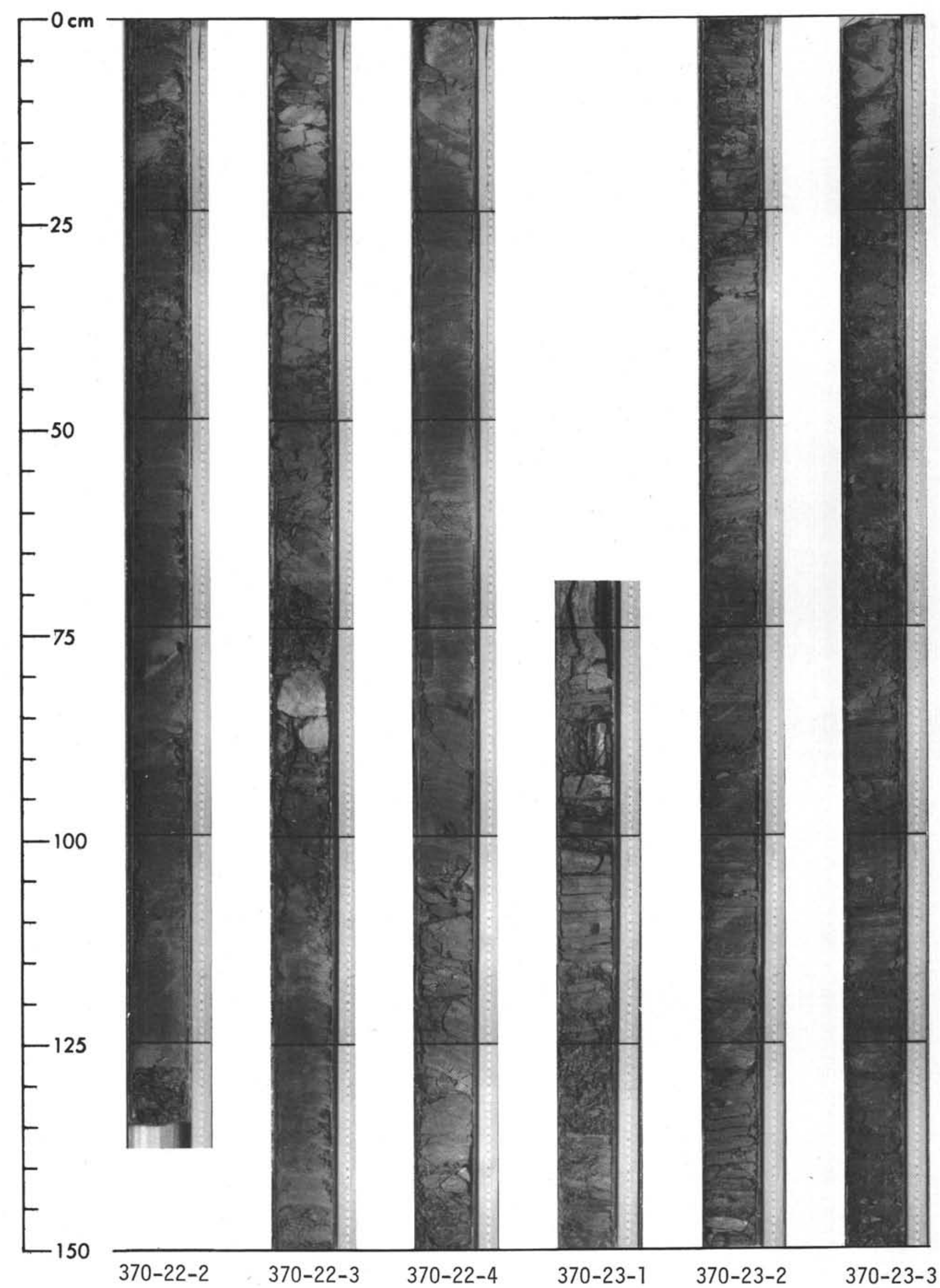




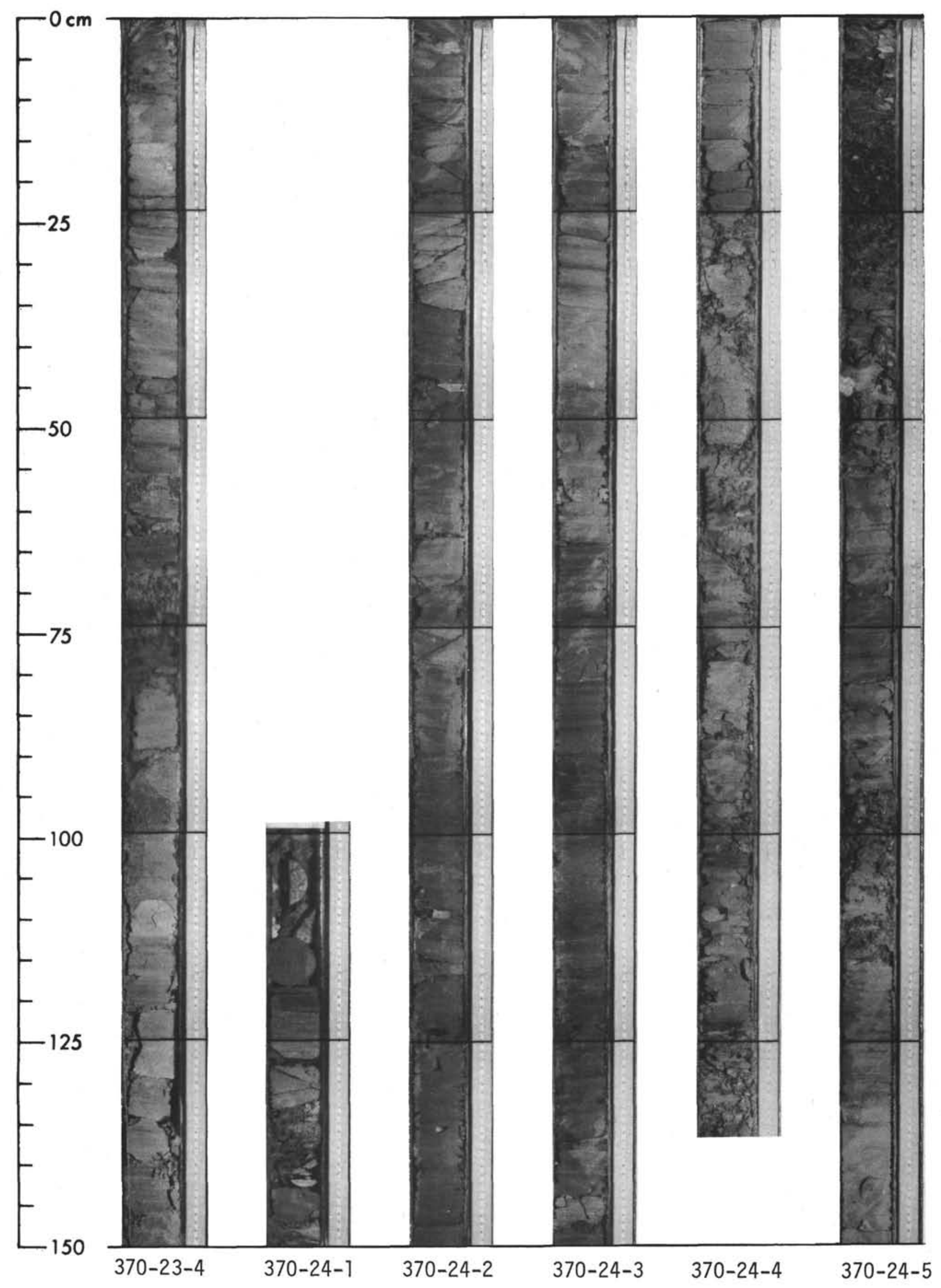




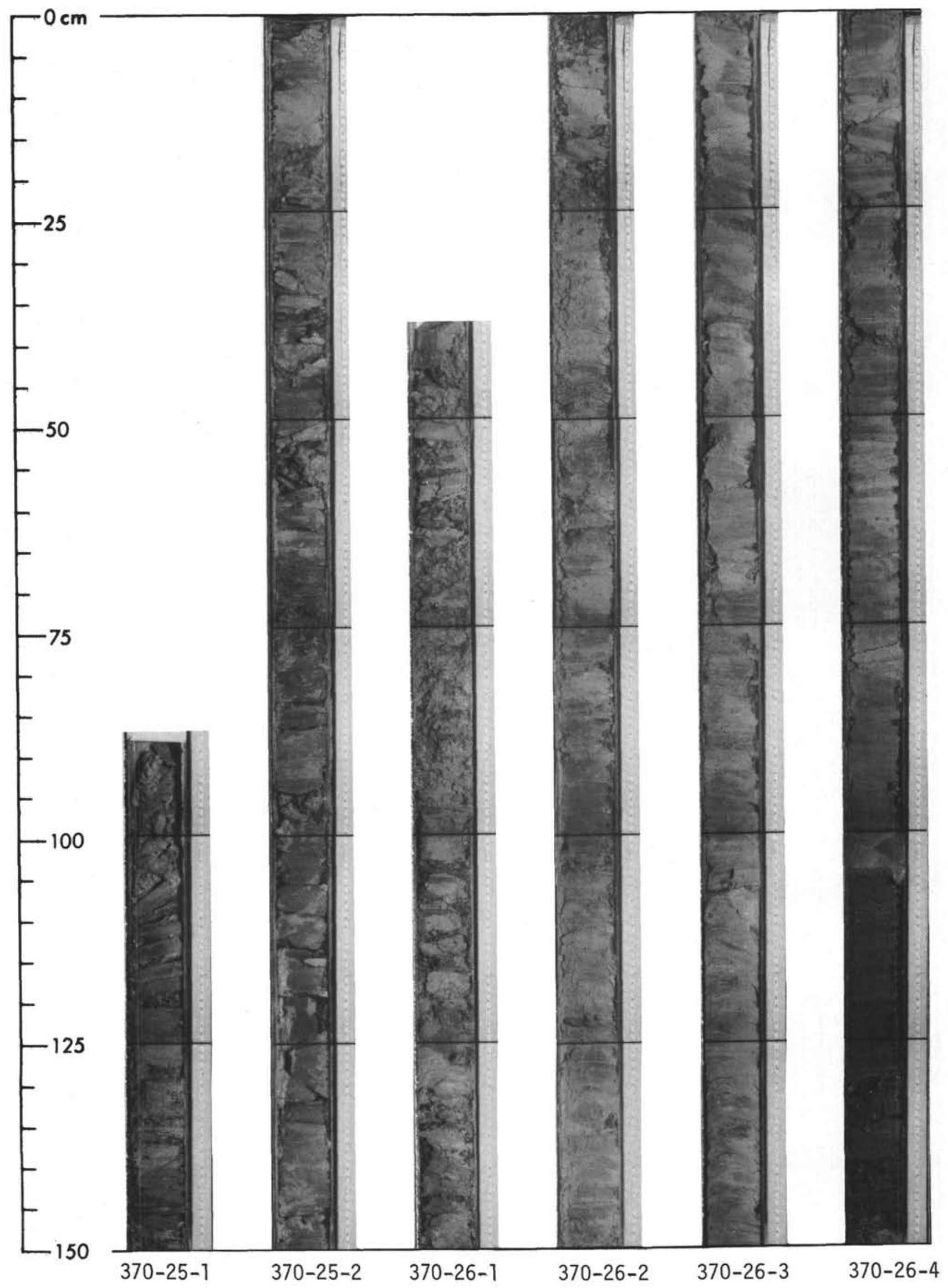




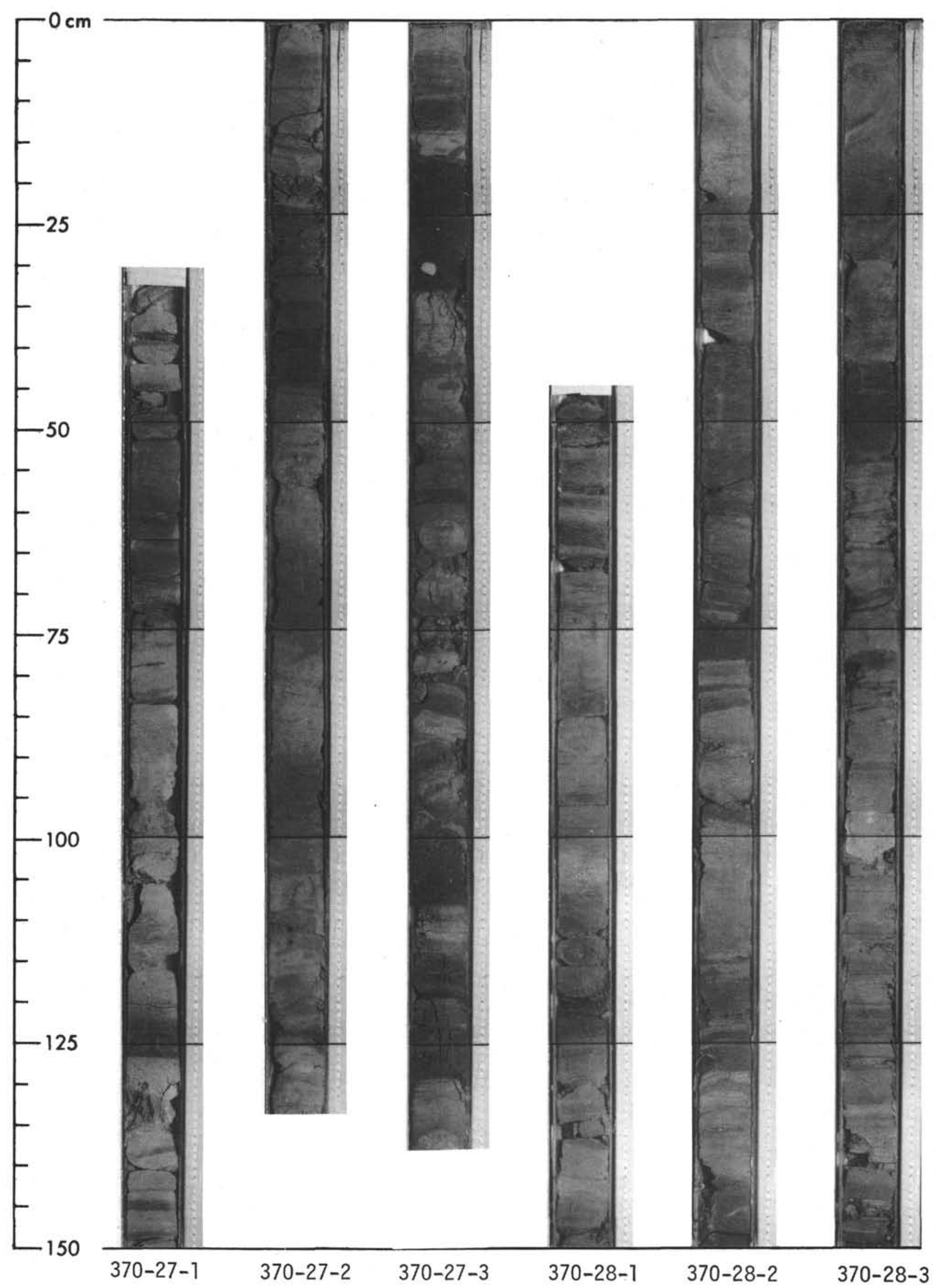




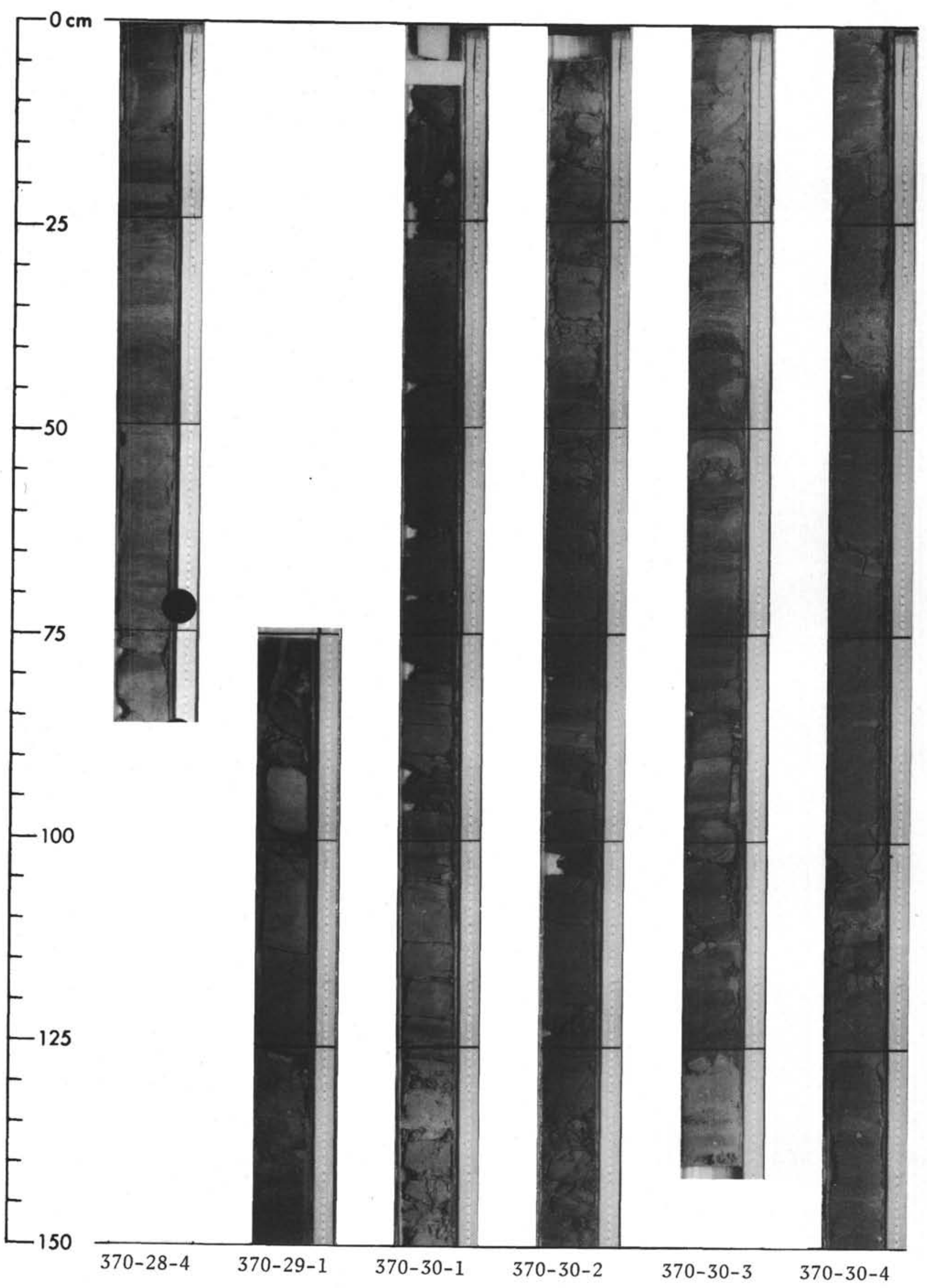




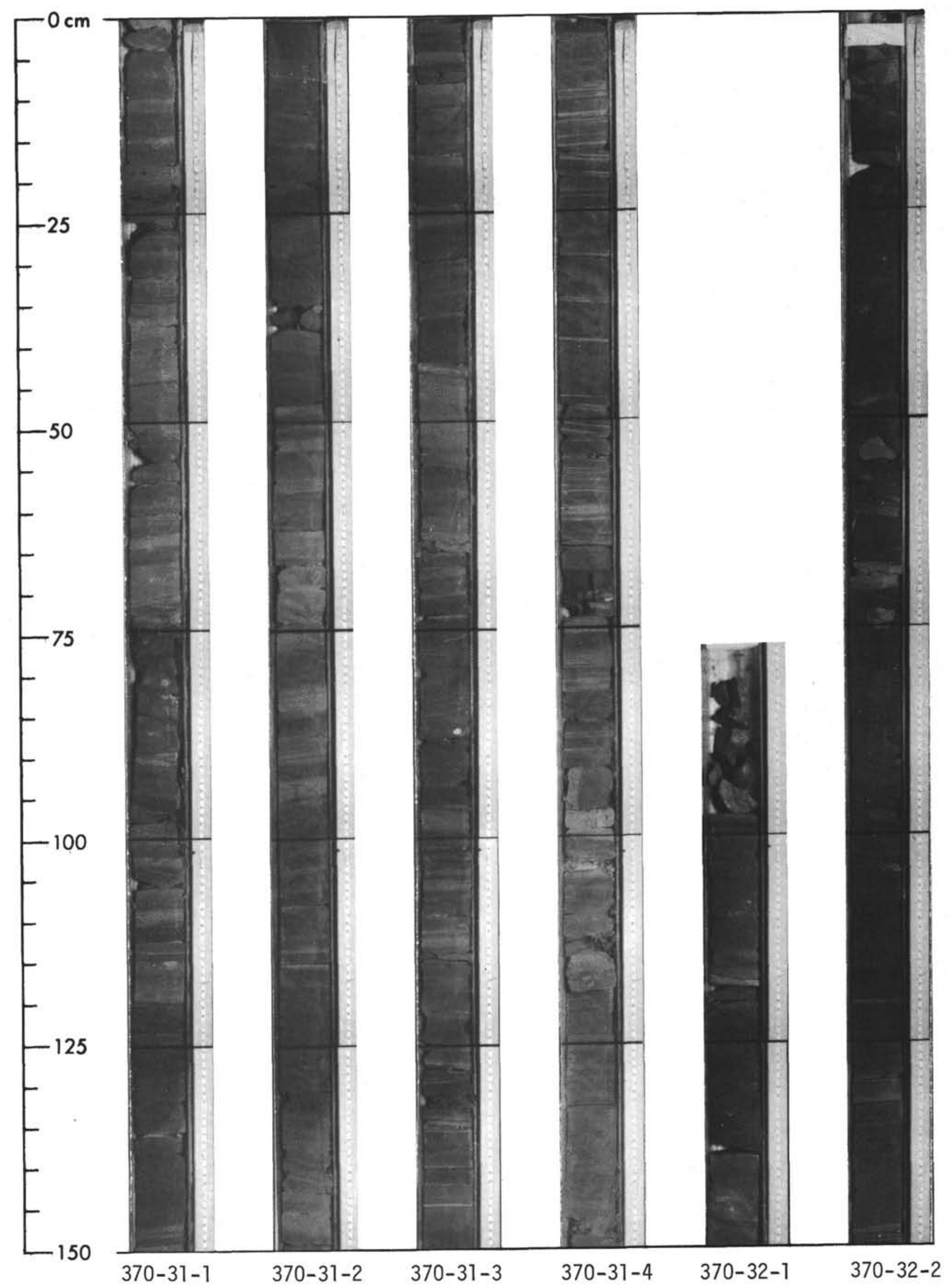


SITE 370: DEEP BASIN OFF MOROCCO

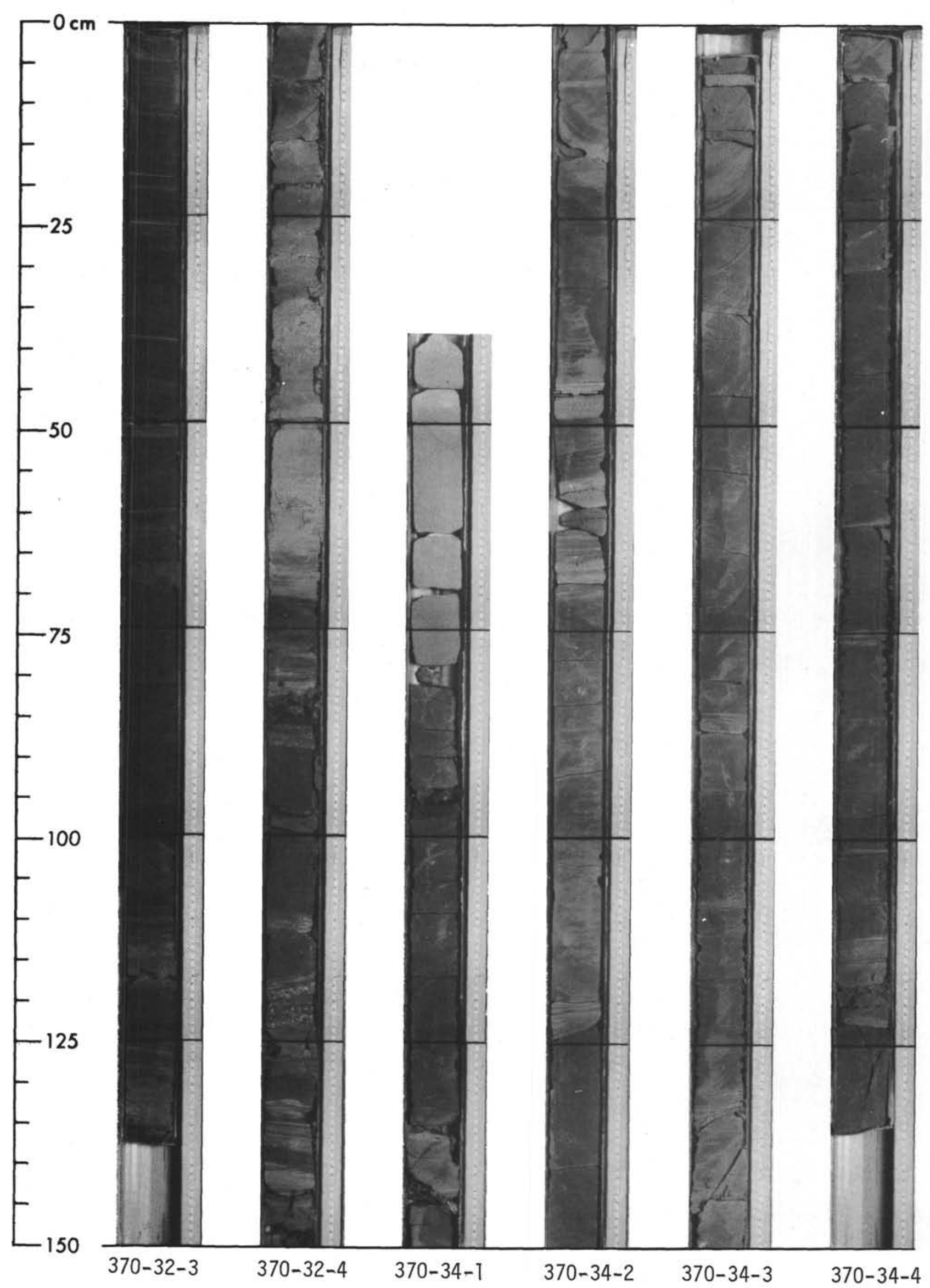




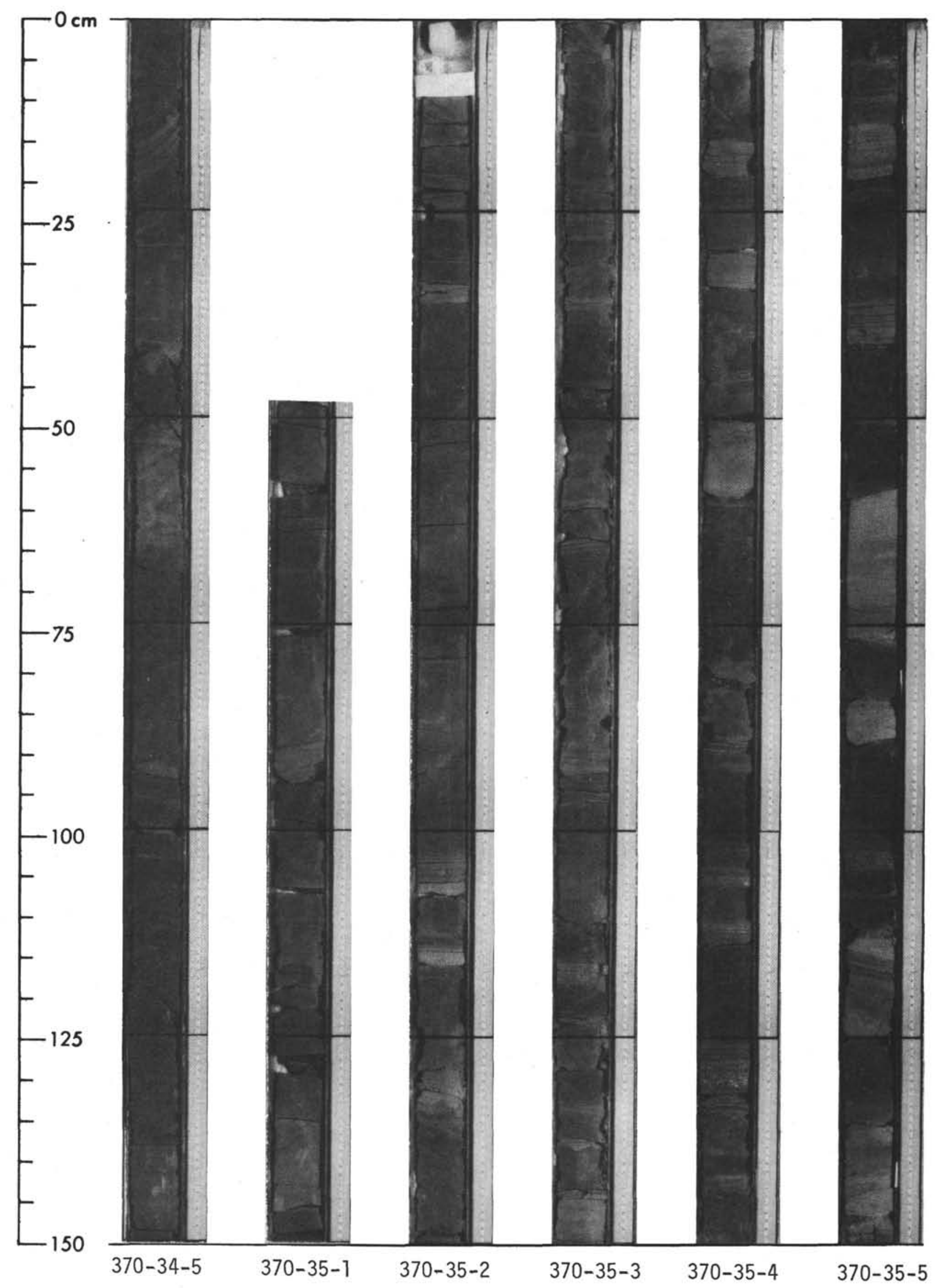


SITE 370: DEEP BASIN OFF MOROCCO

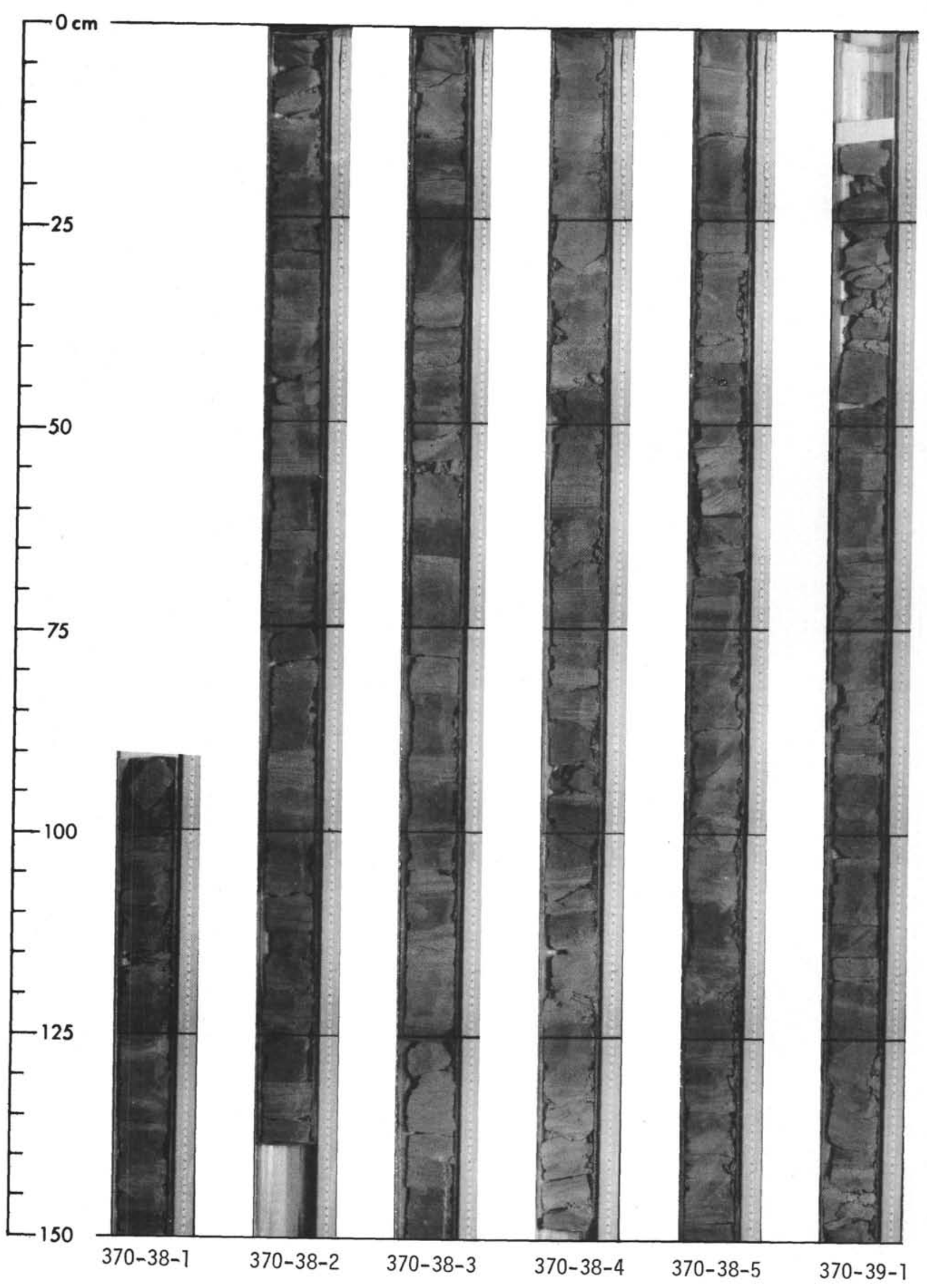




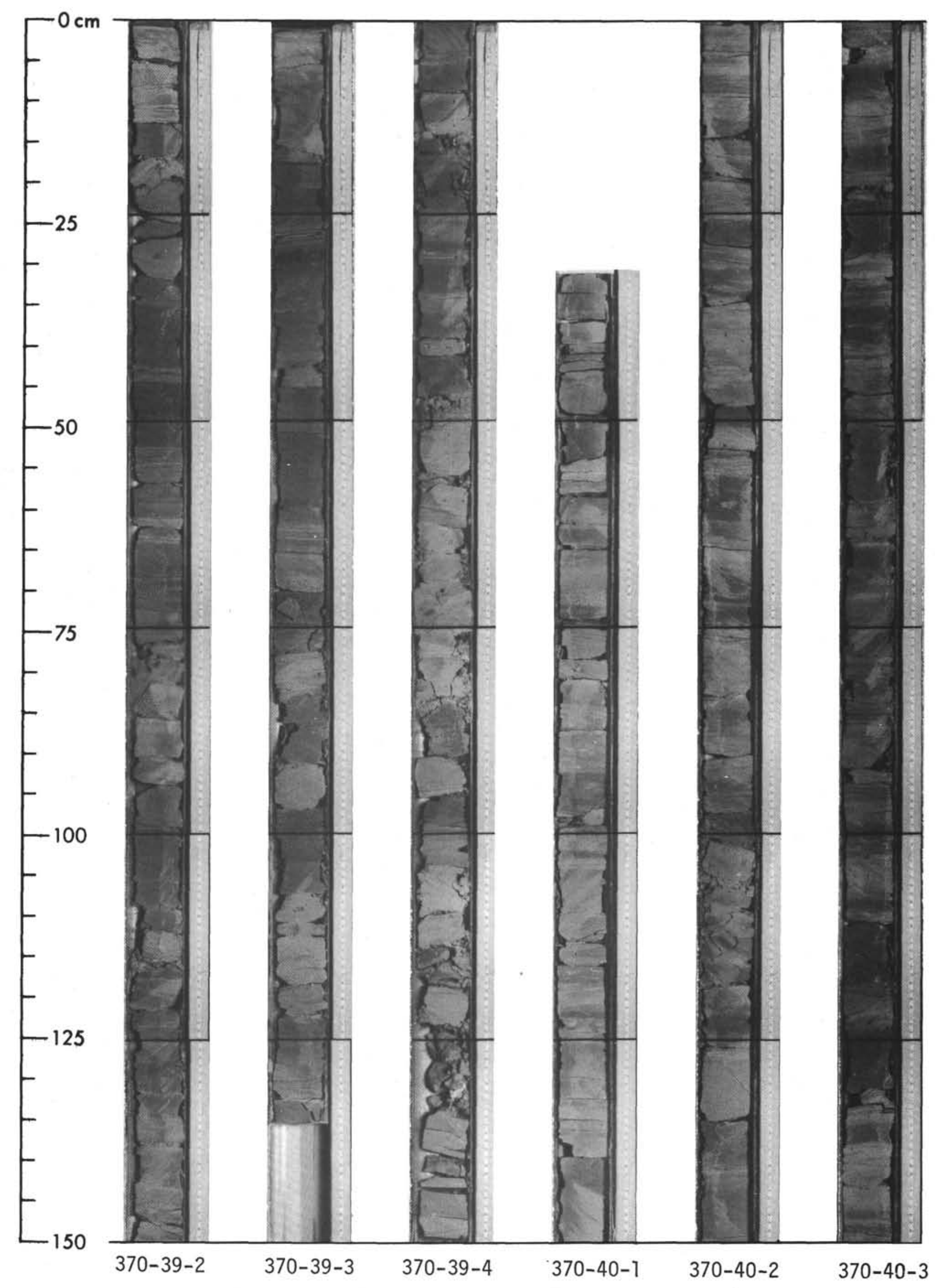




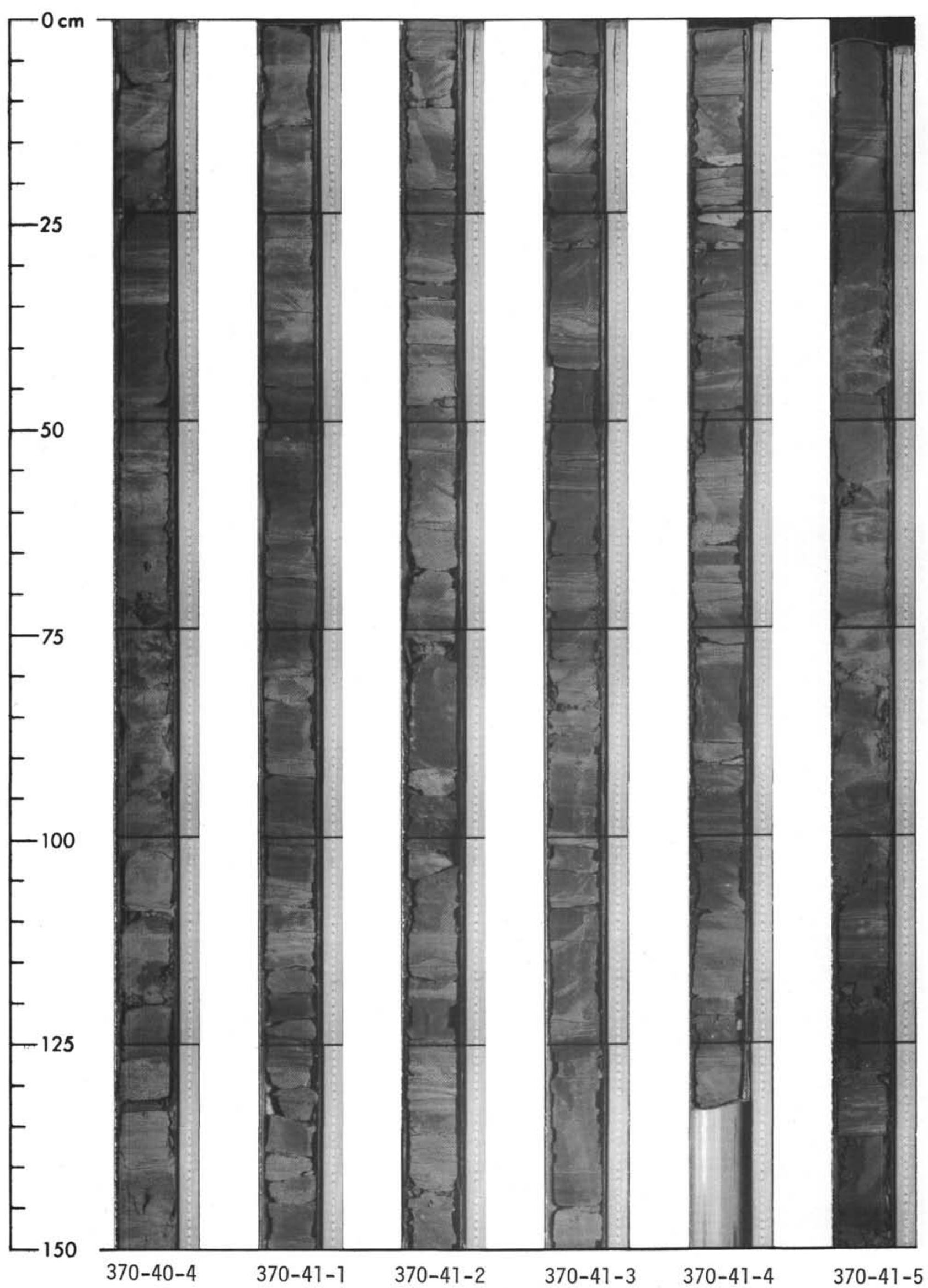


SITE 370: DEEP BASIN OFF MOROCCO

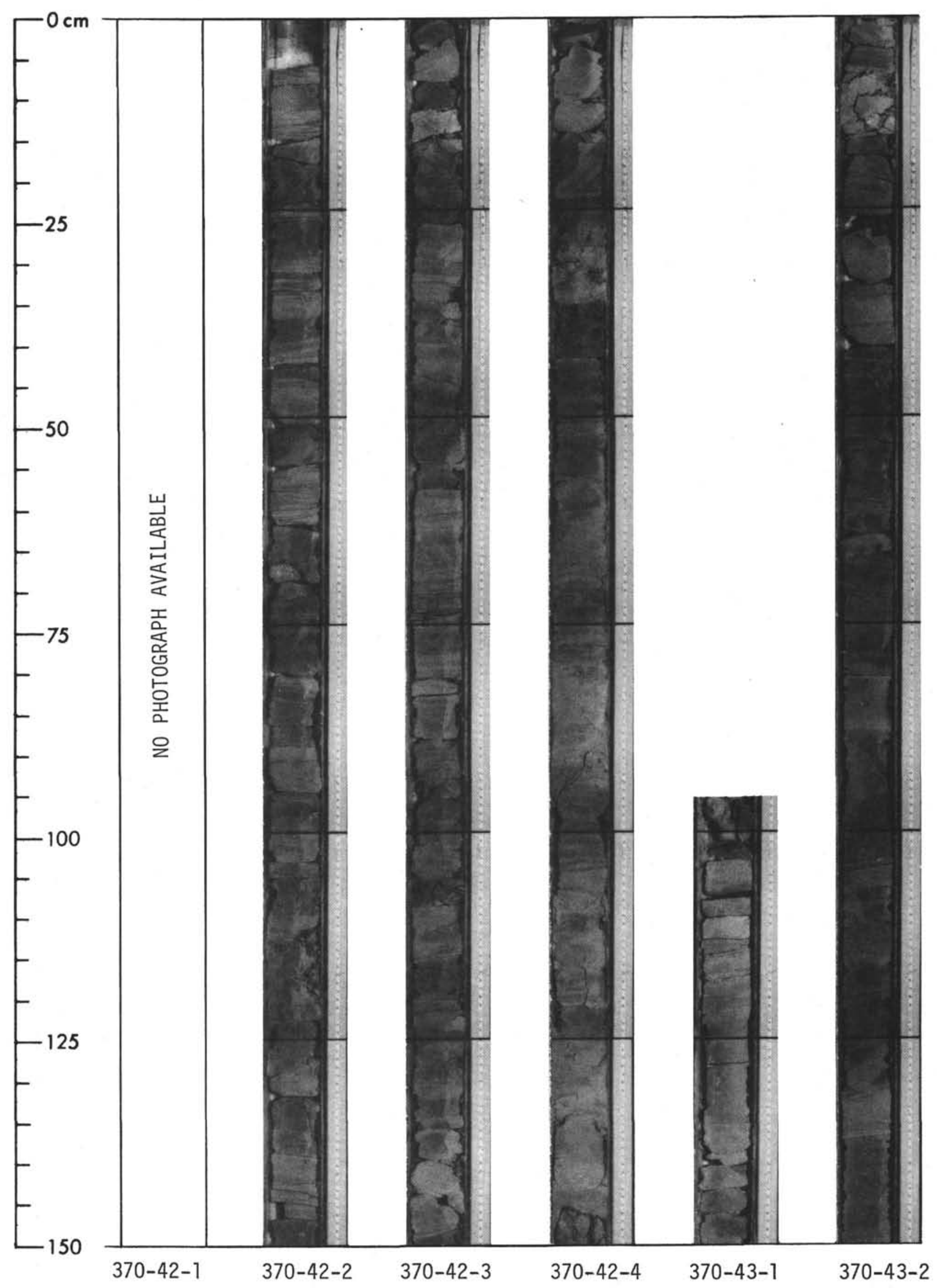




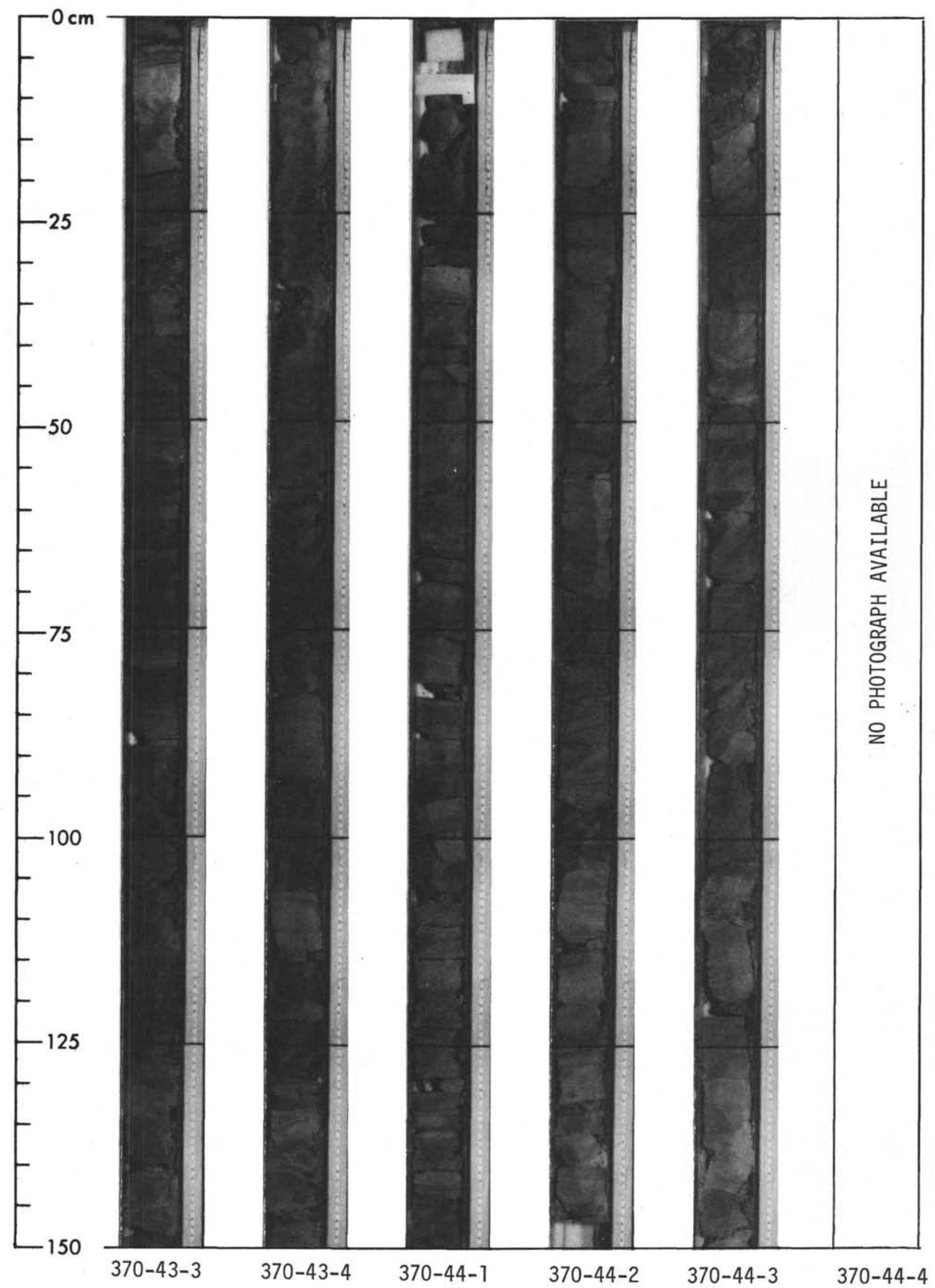




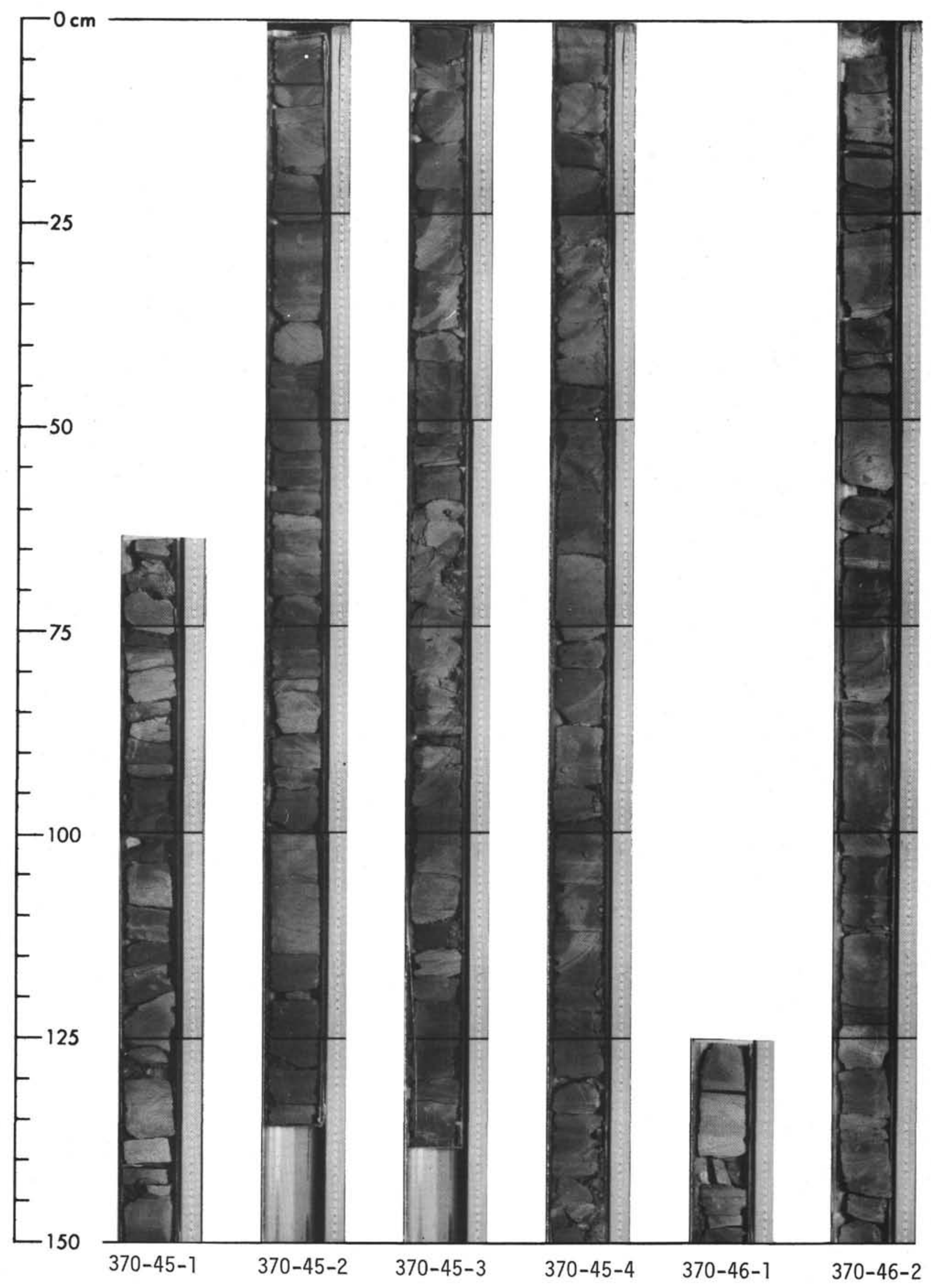


SITE 370: DEEP BASIN OFF MOROCCO

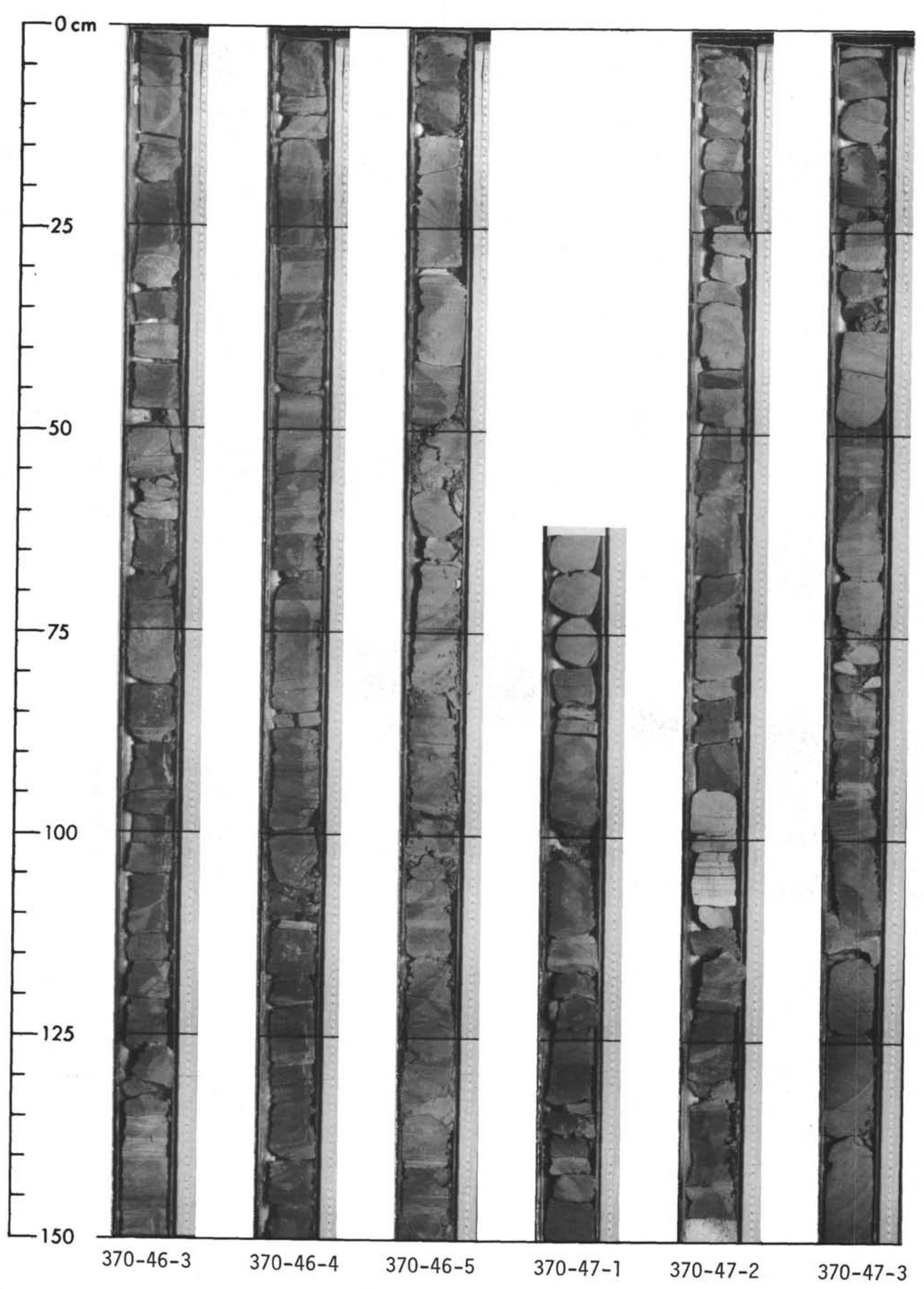




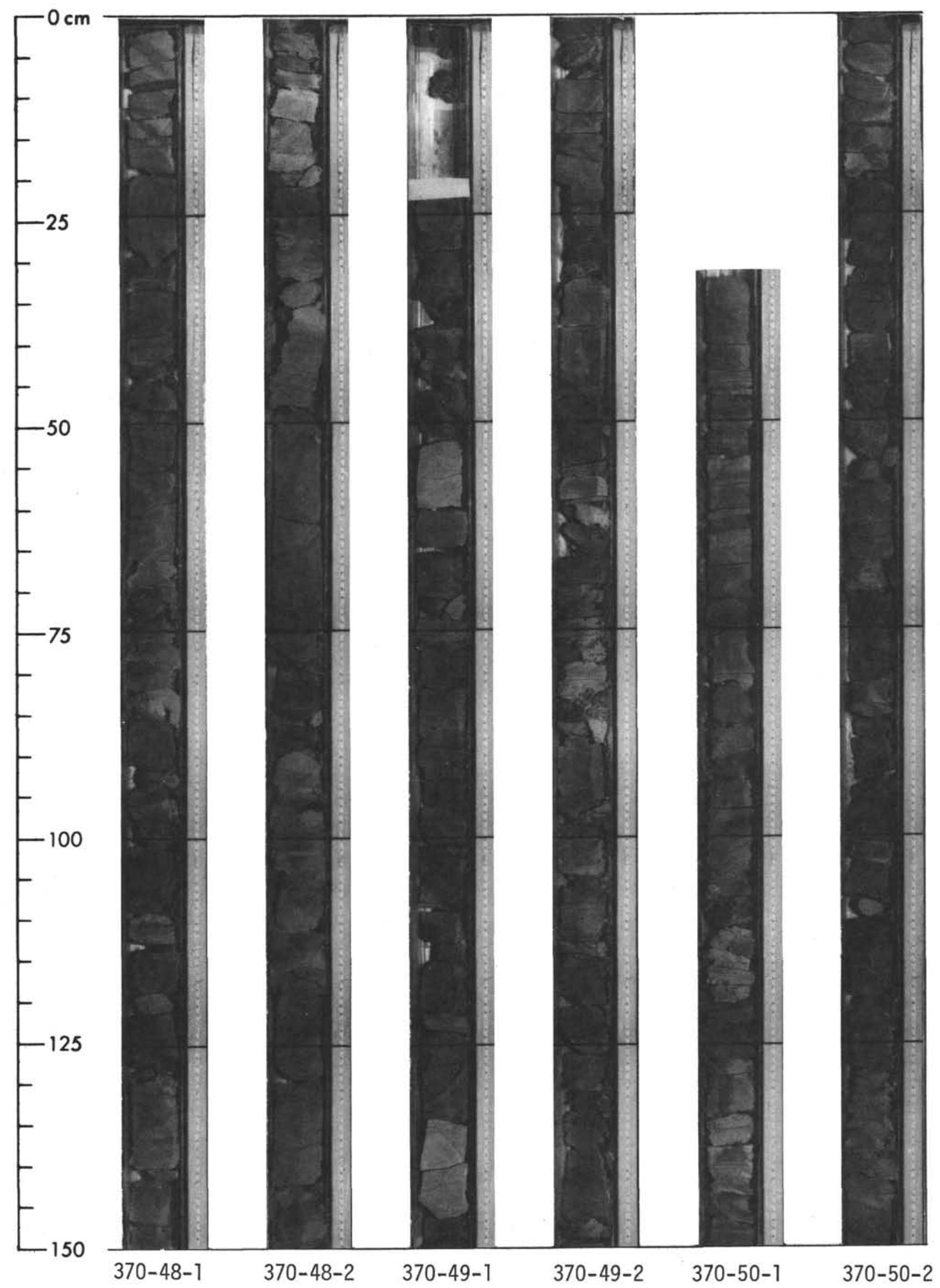




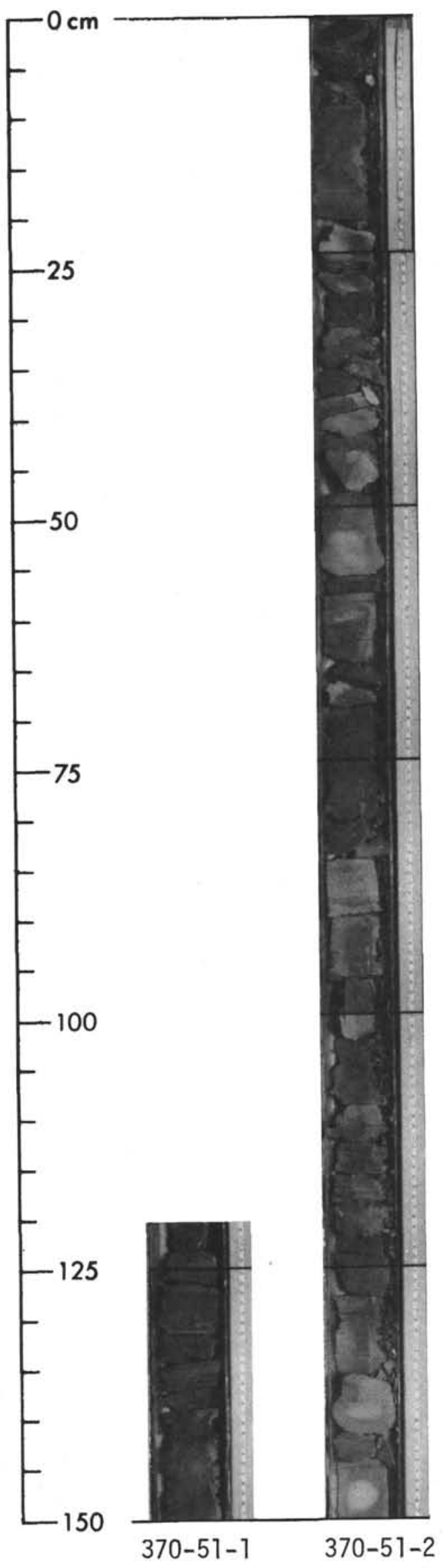

